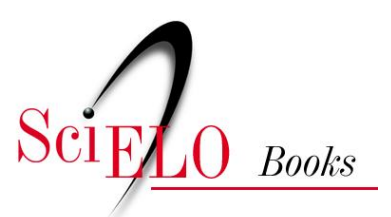

\title{
Ordem Perciformes
}

\author{
Ana Cristina Teixeira Bonecker \\ Claudia Akemi Pereira Namiki \\ Márcia Salustiano de Castro \\ Paula Nepomuceno Campos
}

\section{SciELO Books / SciELO Livros / SciELO Libros}

BONECKER, ACT., et al. Ordem Perciformes. In Catalogo dos estágios iniciais de desenvolvimento dos peixes da bacia de Campos [online]. Curitiba: Sociedade Brasileira de Zoologia, 2014, pp. 180265. Zoologia: guias e manuais de identificação series. ISBN 978-85-98203-10-2. Available from

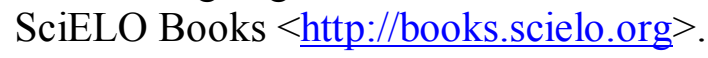

\section{(2)(1)(2)}

All the contents of this chapter, except where otherwise noted, is licensed under a Creative Commons Attribution-Non Commercial-ShareAlike 3.0 Unported.

Todo o conteúdo deste capítulo, exceto quando houver ressalva, é publicado sob a licença Creative Commons Atribuição Uso Não Comercial - Partilha nos Mesmos Termos 3.0 Não adaptada.

Todo el contenido de este capítulo, excepto donde se indique lo contrario, está bajo licencia de la licencia Creative Commons Reconocimento-NoComercial-CompartirIgual 3.0 Unported. 


\section{ORDEM PERCIFORMES}

A ordem Perciformes é a mais diversa de todas as ordens de peixes e a maior ordem dos vertebrados. Contem 20 subordens, 160 famílias e mais de 10.000 espécies. As características que unem as famílias pertencentes a essa ordem são: presença de espinhos nas nadadeiras dorsal e anal; um espinho e cinco ou menos raios na nadadeira pélvica; ausência de nadadeira adiposa; presença de 17 ou menos raios principais na nadadeira caudal; e presença de quatro arcos branquiais.

Essa ordem é muito bem representada no litoral brasileiro e na área de estudo foi constituída por 26 famílias: Acropomatidae, Serranidae, Symphysanodontidae, Apogonidae, Pomatomidae, Carangidae, Coryphaenidae, Gerreidae, Mullidae, Chaetodontidae, Bramidae, Pomacanthidae, Cirrhitidae, Mugilidae, Pomacentridae, Labridae, Scaridae, Chiasmodontidae, Callionymidae, Gobiidae, Microdesmidae, Acanthuridae, Sphyraenidae, Gempylidae, Scombridae e Nomeidae. 


\section{Família Acropomatidae}

A família Acropomatidae é marinha, bentopelágica e ocorre nos oceanos Atlântico, Índico e Pacífico. Compreende oito gêneros com 31 espécies. Possuem nadadeira dorsal separada em duas partes. A primeira com VII-X espinhos; a segunda pode ter ou não espinho e tem 8-10 raios. A nadadeira anal tem II-III espinhos e 7-9 raios. Possuem 25 vértebras. A região da cabeça tem muitos espinhos bem desenvolvidos na região occipital, supra-ocular, frontal, opercular e pós-temporal. O tamanho dos espinhos da cabeça é uma característica diagnóstica das espécies, assim como o padrão de pigmentação na região dorsal, na base da nadadeira; podendo ou não haver melanóforos no pedúnculo caudal. A porção posterior da cabeça e o intestino possuem muitos pigmentos pequenos e aglomerados.

No Brasil já foram identificadas duas espécies nas fases de larva e adulto: Synagrops bellus (Goode \& Bean, 1896) e Synagrops spinosus Schultz, 1940. Nesse estudo é contemplada a espécie Synagrops spinosus. 


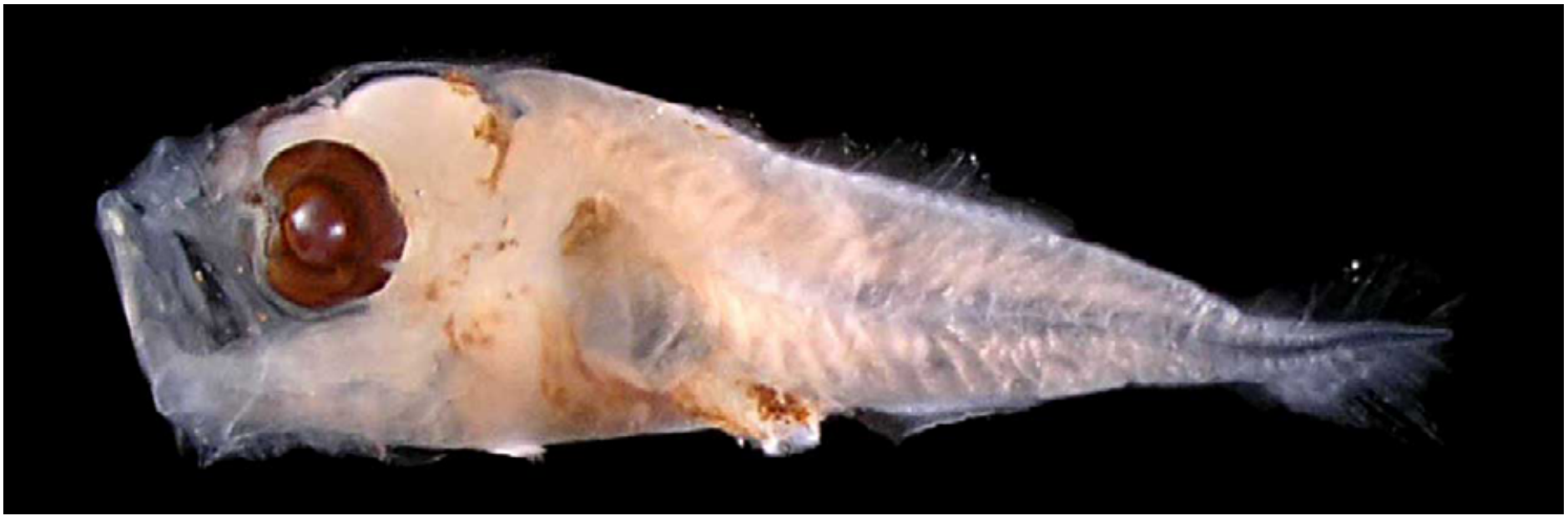

Figura 103 - A: Synagrops spinosus. DZUFRJ 22332; Pré-flexão; CP 4,5mm.

\section{Synagrops spinosus Schultz, 1940}

As larvas têm o corpo fusiforme e comprimido lateralmente. A boca é grande, quase vertical. Os espinhos da cabeça são bem desenvolvidos, principalmente na margem do pré-opérculo e opérculo, quando comparados aos demais representantes desse gênero. Possui crista su-

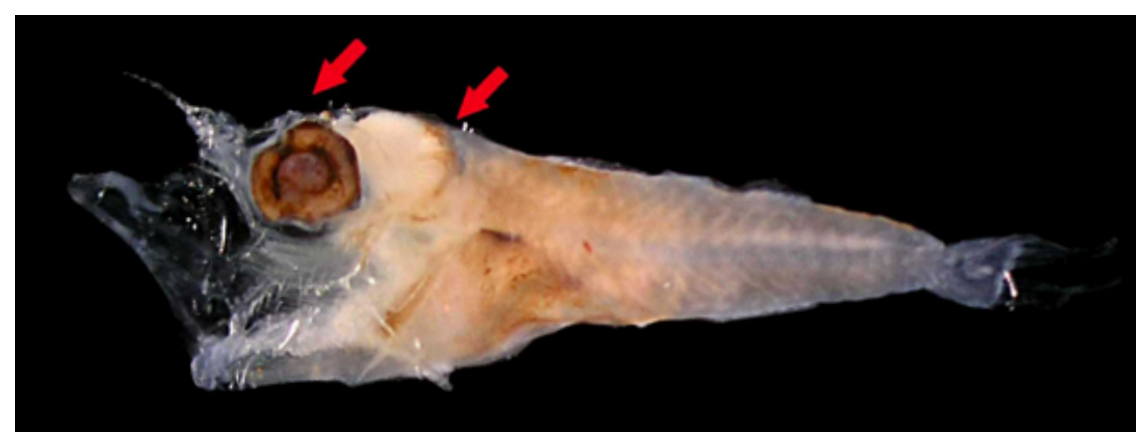

Figura 103 - B: DZUFRJ 22331; Flexão; CP 5,0 mm. praoccipital e frontal grande e serrilhada. Acima dos olhos a crista é menor e serrilhada. A margem do pré-opérculo possui espinhos bem desenvolvidos, serrilhados e com espículas. As larvas em pré-flexão não possuem pigmentos no pedúnculo caudal, mas já possuem muitos pigmentos difusos na parte posterior da cabeça, na região nucal. Após a flexão o pedúnculo caudal apresenta pigmentos cuja concentração aumenta com o desenvolvimento da larva. No corpo a pigmentação concentra-se na base das nadadeiras dorsal e anal. Número total de miômeros: 25.

Tamanho: pré-flexão 4,5 mm; flexão 5,0 mm.

Habitat: espécie marinha, bentopelágica. Ocorre em águas tropicais e subtropicais, na margem da plataforma continental e de ilhas, em profundidades entre 87 e $544 \mathrm{~m}$.

\section{Georreferencimento}

\begin{tabular}{|c|c|c|c|c|c|c|c|c|}
\hline DZUFR & Latitude (S) & Longitude (W) & Data & $\begin{array}{c}\text { Tipo de } \\
\text { arrasto }\end{array}$ & $\begin{array}{c}\text { Profundidade } \\
\text { de coleta }\end{array}$ & Rede & $\begin{array}{c}\text { Malha } \\
\text { ( } \boldsymbol{\mu m})\end{array}$ & $\begin{array}{c}\mathbf{N}^{\circ} \text {. de } \\
\text { inds. }\end{array}$ \\
\hline 22331 & $21^{\circ} 53^{\prime} 10,4^{\prime \prime}$ & $039^{\circ} 45^{\prime} 49,9^{\prime \prime}$ & $10 / 10 / 2001$ & oblíquo & $1.000 \mathrm{~m}$ & cilíndrico-cônica & 500 & 1 \\
\hline 22332 & $22^{\circ} 32^{\prime} 49,0^{\prime \prime}$ & $040^{\circ} 04^{\prime} 20,9^{\prime \prime}$ & $07 / 11 / 2001$ & oblíquo & $1.000 \mathrm{~m}$ & cilíndrico-cônica & 500 & 1 \\
\hline
\end{tabular}

Referências: Heemstra, 2002; Ruiz-Carus, 2006; Fahay, 2007. 


\section{Família Serranidae}

A família Serranidae compreende a maioria dos peixes marinhos de importância comercial e recreativa do mundo. É composta por aproximadamente 64 gêneros e 475 espécies. São os principais habitantes das águas costeiras tropicais, vivendo quase sempre sobre fundos rochosos e coralinos.

As características variam de acordo com a subfamília a que a larva pertence. O desenvolvimento ocorre relativamente rápido, o corpo é comprimido lateralmente, podendo ser moderadamente alongado até muito alto. Os espinhos das nadadeiras podem ser curtos e fracos, ou grandes e serrilhados. Os espinhos presentes no opérculo ou pré-opérculo podem ser reduzidos ou muito distintos e robustos. O padrão de pigmentação varia muito entre as espécies.

No Brasil já foram identificadas 50 espécies. Nesse estudo são contempladas as espécies Dules auriga, Liopropoma carmabi e Pseudogramma gregoryi. 


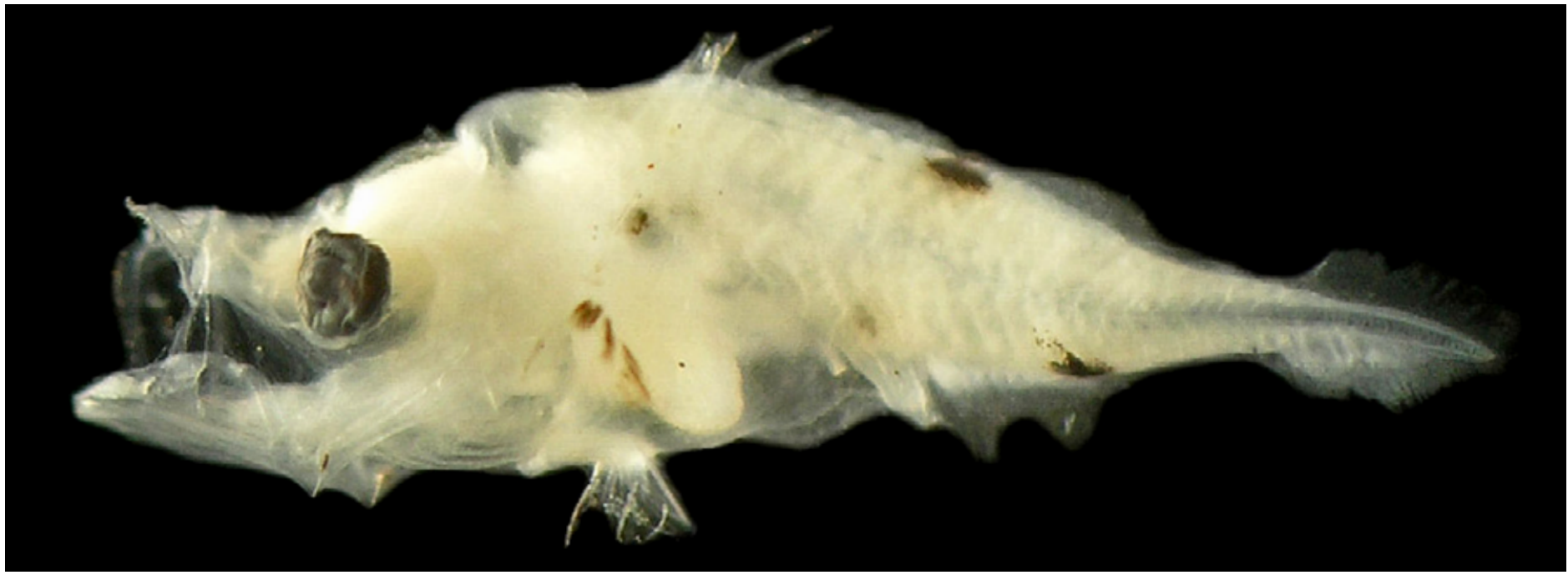

Figura 104 - A: Dules auriga. DZUFRJ 31258; Pré-flexão; CP 4,1mm.

\section{Dules auriga Cuvier, 1829}

As larvas possuem corpo fusiforme e pouco comprimido lateralmente. Existem poucos espinhos na cabeça e na região do opérculo. O terceiro espinho da nadadeira dorsal é longo, mas geralmente é quebrado durante a coleta. Desde a pré-flexão, possui duas grandes manchas de pigmentos dorsais (no final da primeira e da segunda nadadeira dorsal) e ventrais (na base e no fim da nadadeira anal), além de um pequeno pigmento no pedúnculo caudal. Essa pigmentação se torna mais evidente com o desenvolvimento da larva, permanecendo na mesma posição. Presença de pequenos pigmentos nos raios das nadadeiras peitorais, sobre o intestino, na região gular e na região anterior a base da nadadeira pélvica (istmo). Pode apresentar pigmentos na base da notocorda em larvas maiores do que $8,0 \mathrm{~mm}$. As manchas de pigmentos são intensas em algumas partes do corpo (cleitro, ânus, na base da nadadeira anal) e, em alguns casos, no pedúnculo caudal e base da nadadeira dorsal.

Tamanho: pré-flexão 2,0-4,5 mm; flexão 4,0-7,0 mm; pós-flexão 8,0-9,5 mm.

Habitat: espécie marinha e demersal.

Nome vulgar: Mariquita.

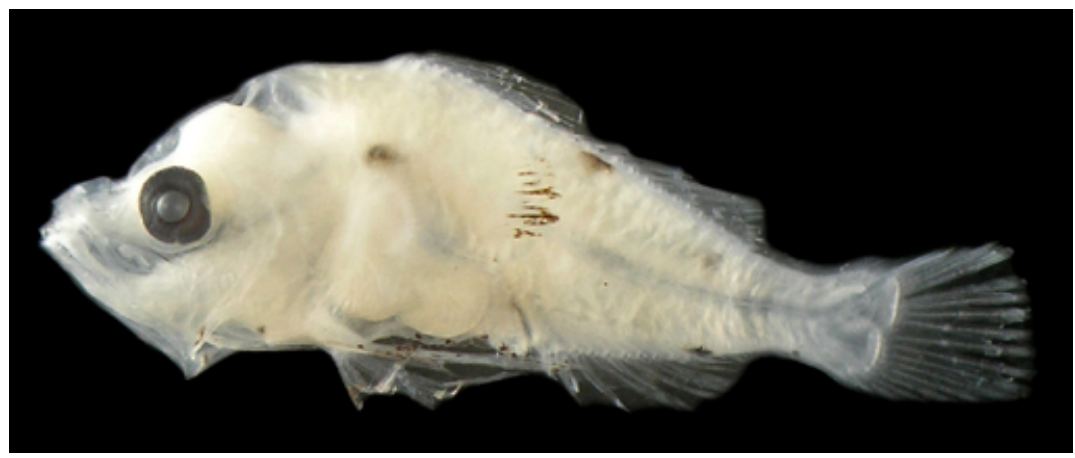

Figura 104 - B: DZUFRJ 31258; Flexão; CP 5,5 mm.

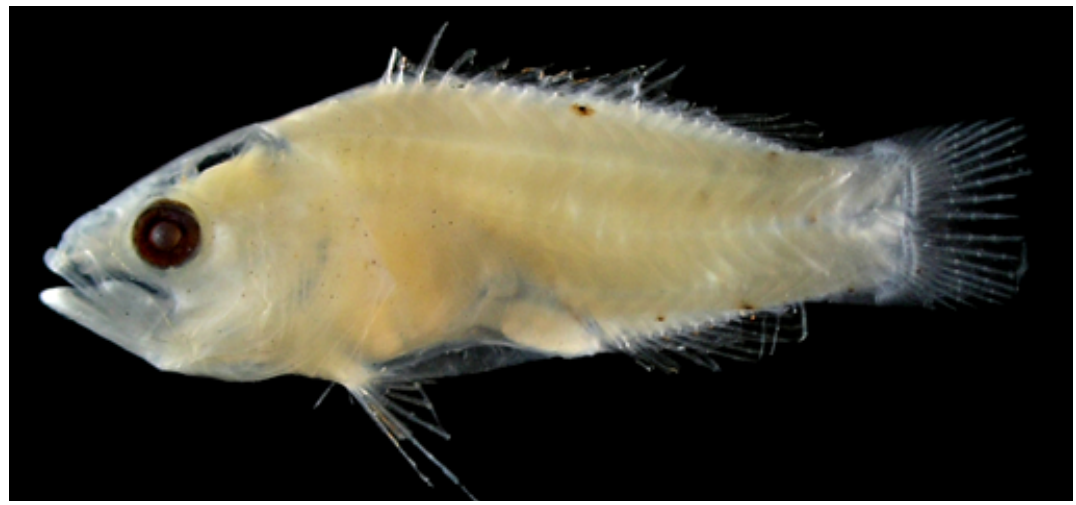

Figura 104 - C: DZUFRJ 586; Pós-flexão; CP 9,5 mm. 


\section{Georreferenciamento}

\begin{tabular}{|c|c|c|c|c|c|c|c|c|}
\hline DZUFRJ & Latitude (S) & Longitude (W) & Data & $\begin{array}{l}\text { Tipo de } \\
\text { arrasto }\end{array}$ & $\begin{array}{c}\text { Profundidade } \\
\text { de coleta }\end{array}$ & Rede & $\begin{array}{c}\text { Malha } \\
(\mu \mathrm{m})\end{array}$ & $\begin{array}{l}N^{\circ} \text {. de } \\
\text { inds. }\end{array}$ \\
\hline 449 & $22^{\circ} 33^{\prime} 47,7^{\prime \prime}$ & $040^{\circ} 12^{\prime} 20,5^{\prime \prime}$ & $17 / 05 / 2002$ & oblíquo & $50 \mathrm{~m}$ & bongô & 500 & 4 \\
\hline 455 & $22^{\circ} 33^{\prime} 37,0^{\prime \prime}$ & $040^{\circ} 19^{\prime} 10,0^{\prime \prime}$ & $17 / 05 / 2002$ & oblíquo & $50 \mathrm{~m}$ & bongô & 330 & 10 \\
\hline 456 & $22^{\circ} 33^{\prime} 45,8^{\prime \prime}$ & $040^{\circ} 13^{\prime} 22,9^{\prime \prime}$ & $17 / 05 / 2002$ & oblíquo & $800 \mathrm{~m}$ & cilíndrico-cônica & 500 & 1 \\
\hline 461 & $22^{\circ} 38^{\prime} 29,0^{\prime \prime}$ & $040^{\circ} 17^{\prime} 40,0^{\prime \prime}$ & $18 / 05 / 2002$ & oblíquo & $800 \mathrm{~m}$ & cilíndrico-cônica & 500 & 4 \\
\hline 518 & $22^{\circ} 34^{\prime} 05,0^{\prime \prime}$ & $040^{\circ} 19^{\prime} 40,0^{\prime \prime}$ & $17 / 05 / 2002$ & oblíquo & $600 \mathrm{~m}$ & cilíndrico-cônica & 500 & 24 \\
\hline 523 & $22^{\circ} 31^{\prime} 27,0^{\prime \prime}$ & $040^{\circ} 16^{\prime} 56,0^{\prime \prime}$ & $17 / 05 / 2002$ & oblíquo & $600 \mathrm{~m}$ & cilíndrico-cônica & 500 & 17 \\
\hline 538 & $22^{\circ} 42^{\prime} 06,0^{\prime \prime}$ & $040^{\circ} 14^{\prime} 26,0^{\prime \prime}$ & $19 / 05 / 2002$ & oblíquo & $50 \mathrm{~m}$ & bongô & 330 & 1 \\
\hline 564 & $22^{\circ} 32^{\prime} 03,0^{\prime \prime}$ & $040^{\circ} 17^{\prime} 21,0^{\prime \prime}$ & 19/05/2002 & oblíquo & $30 \mathrm{~m}$ & bongô & 500 & 1 \\
\hline 586 & $22^{\circ} 33^{\prime} 47,7^{\prime \prime}$ & $040^{\circ} 12^{\prime} 20,5^{\prime \prime}$ & $17 / 05 / 2002$ & oblíquo & $50 \mathrm{~m}$ & bongô & 330 & 1 \\
\hline 630 & $22^{\circ} 36^{\prime} 54,9^{\prime \prime}$ & $040^{\circ} 09^{\prime} 19,4^{\prime \prime}$ & $16 / 05 / 2002$ & oblíquo & $50 \mathrm{~m}$ & bongô & 500 & 1 \\
\hline 636 & $22^{\circ} 36^{\prime} 54,9^{\prime \prime}$ & $040^{\circ} 09^{\prime} 19,4^{\prime \prime}$ & $16 / 05 / 2002$ & oblíquo & $50 \mathrm{~m}$ & bongô & 330 & 2 \\
\hline 644 & $22^{\circ} 38^{\prime} 25,0^{\prime \prime}$ & $040^{\circ} 17^{\prime} 41,0^{\prime \prime}$ & $19 / 05 / 2002$ & oblíquo & $40 \mathrm{~m}$ & bongô & 330 & 1 \\
\hline 673 & $22^{\circ} 41^{\prime} 54,7^{\prime \prime}$ & $040^{\circ} 14^{\prime} 04,5^{\prime \prime}$ & $16 / 05 / 2002$ & oblíquo & $1.000 \mathrm{~m}$ & cilíndrico-cônica & 500 & 3 \\
\hline 677 & $22^{\circ} 37^{\prime} 35,5^{\prime \prime}$ & $040^{\circ} 09^{\prime} 32,8^{\prime \prime}$ & $16 / 05 / 2002$ & oblíquo & $1.000 \mathrm{~m}$ & cilíndrico-cônica & 500 & 1 \\
\hline 1358 & $22^{\circ} 02^{\prime} 30,0^{\prime \prime}$ & $039^{\circ} 49^{\prime} 41,2^{\prime \prime}$ & $12 / 05 / 2002$ & oblíquo & $\begin{array}{c}\text { até a } \\
\text { termoclina }\end{array}$ & bon & 330 & 1 \\
\hline 19781 & $22^{\circ} 07^{\prime} 58,8^{\prime \prime}$ & $039^{\circ} 49^{\prime} 08,9^{\prime \prime}$ & $01 / 12 / 2002$ & vertical & $0-50 m$ & cilíndrico-cônica & 500 & 1 \\
\hline 22191 & $22^{\circ} 39,68^{\prime}$ & $040^{\circ} 03,24^{\prime}$ & $13 / 06 / 2003$ & vertical & $0-60 m$ & cilíndrico-cônica & 500 & 1 \\
\hline
\end{tabular}

Referências: Figueiredo \& Menezes, 1980; Watson, 1996c; Heemstra \& Randall, 2002; Richards et al., 2006; Fahay, 2007. 


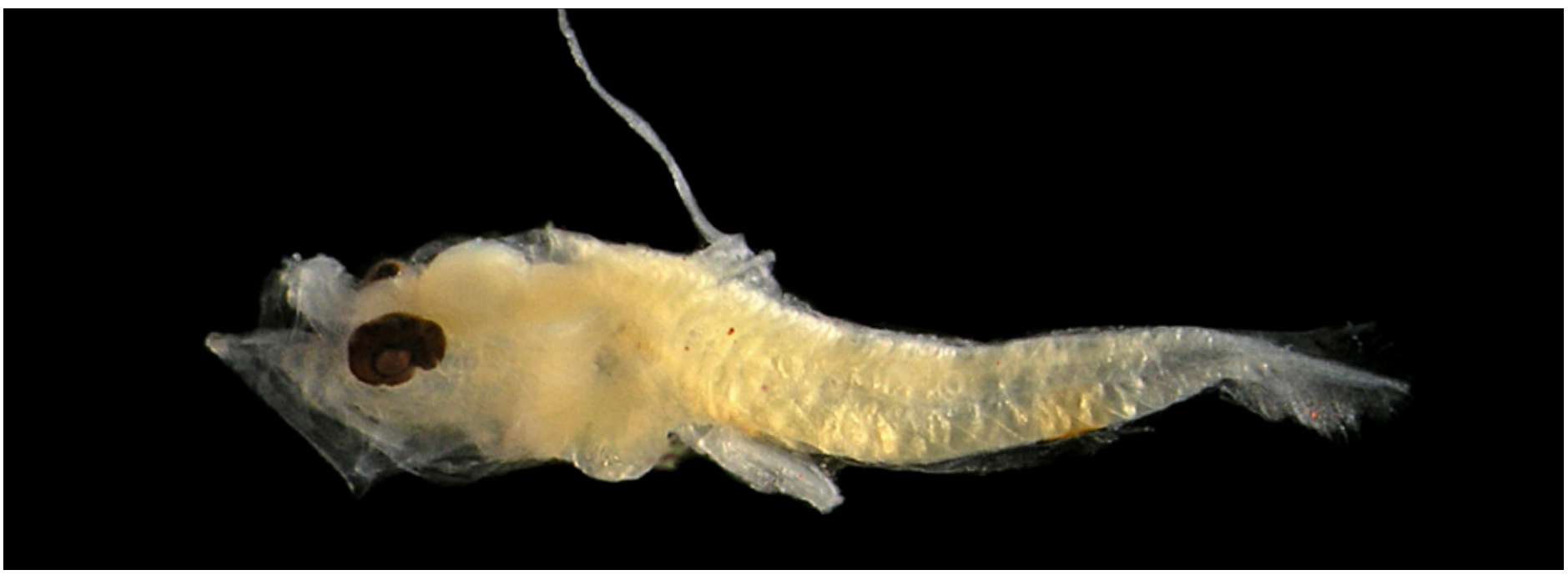

Figura 105 - A: Liopropoma carmabi. DZUFRJ 22488; Pré-flexão; CP 3,5 mm.

\section{Liopropoma carmabi (Randall, 1963)}

Possui nadadeira dorsal dupla, sendo a primeira com oito espinhos e a segunda dorsal 12-13 raios. O segundo e o terceiro espinhos dorsais são longos, com extremidades filamentosas, que se assemeIham a apêndices e normalmente são quebrados durante as coletas. A nadadeira anal tem três espinhos e oito raios. Os pigmentos são encontrados espalhados na cabeça e entre os apêndices da nadadeira dorsal. O pedúnculo caudal é alto.

Tamanho: pré-flexão 3,5 mm; transformação 20,5 $\mathrm{mm}$.

Habitat: espécie marinha, demersal, associada à regiões de recifes, ocorre entre 15 e $70 \mathrm{~m}$ de

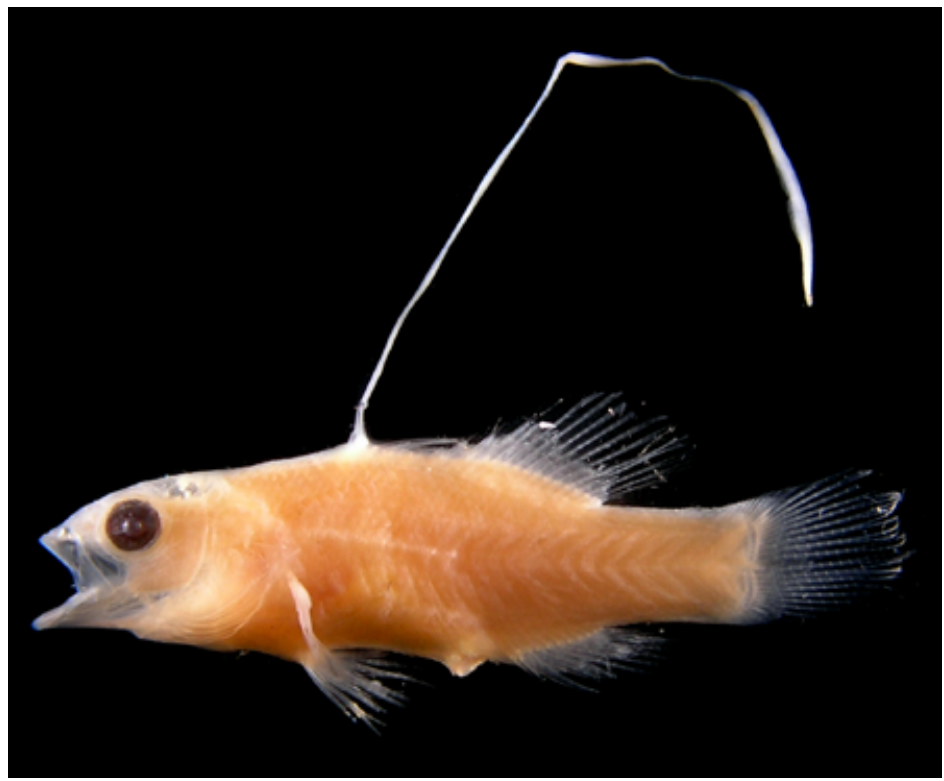

Figura 105 - B: DZUFRJ 5396; Transformação; CP 20,5 mm. profundidade.

Nome vulgar: Mariquita arlequim.

\section{Georreferenciamento}

\begin{tabular}{|c|c|c|c|c|c|c|c|c|}
\hline DZUFR & Latitude (S) & Longitude (W) & Data & $\begin{array}{c}\text { Tipo de } \\
\text { arrasto }\end{array}$ & $\begin{array}{c}\text { Profundidade } \\
\text { de coleta }\end{array}$ & Rede & $\begin{array}{c}\text { Malha } \\
\text { ( } \boldsymbol{\mu m}^{\prime}\end{array}$ & $\begin{array}{c}\mathbf{N}^{\circ} \text {. de } \\
\text { inds. }\end{array}$ \\
\hline 5396 & $22^{\circ} 32^{\prime} 50,0^{\prime \prime}$ & $040^{\circ} 04^{\prime} 09,9^{\prime \prime}$ & $06 / 11 / 2001$ & oblíquo & $1.000 \mathrm{~m}$ & cilíndrico-cônica & 500 & 1 \\
\hline 22488 & $22^{\circ} 42^{\prime} 06,0^{\prime \prime}$ & $040^{\circ} 14^{\prime} 26,0^{\prime \prime}$ & $19 / 05 / 2002$ & oblíquo & $50 \mathrm{~m}$ & bongô & 330 & 1 \\
\hline
\end{tabular}

Referências: Figueiredo \& Menezes, 1980; Watson, 1996c; Heemstra \& Randall, 2002; Richards et al., 2006; Fahay, 2007. 


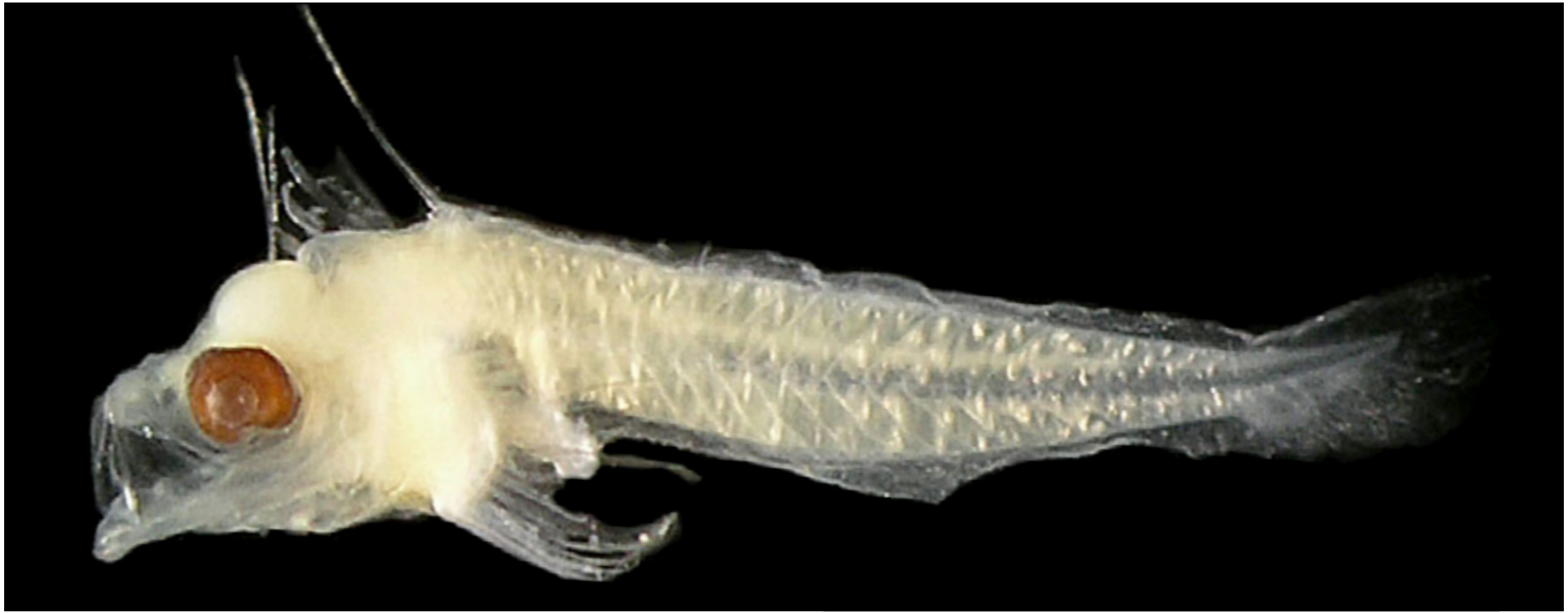

Figura 106 - A: Pseudogramma gregoryi. DZUFRJ 457; Pré-flexão; CP 3,2 mm.

\section{Pseudogramma gregoryi (Breder, 1927)}

Esta espécie é caracterizada por possuir corpo fusiforme e comprimido lateralmente nos estágios inicias de desenvolvimento, ficando mais robusto com o crescimento larval. A nadadeira peitoral tem desenvolvimento precoce, aparecendo desde a pré-flexão, e é bem desenvolvida. O intestino é curto correspondendo a cerca de $25 \%$ CP e a partir do estágio de flexão alcança quase a metade do corpo da larva. Possui VII espinhos na primeira nadadeira dorsal e 18-19 raios na segunda. Apenas o primeiro espinho da primeira dorsal é prolongado, e já está presente desde a pré-flexão. A nadadeira anal é composta por III espinhos e 14-16 raios. O pedúnculo caudal é alto nas larvas em estágio de pós-flexão. Não há pigmentação evidente espalhada pela cabeça ou corpo da larva em todos os estágios de desenvolvimento. Número total de vértebras: 26.

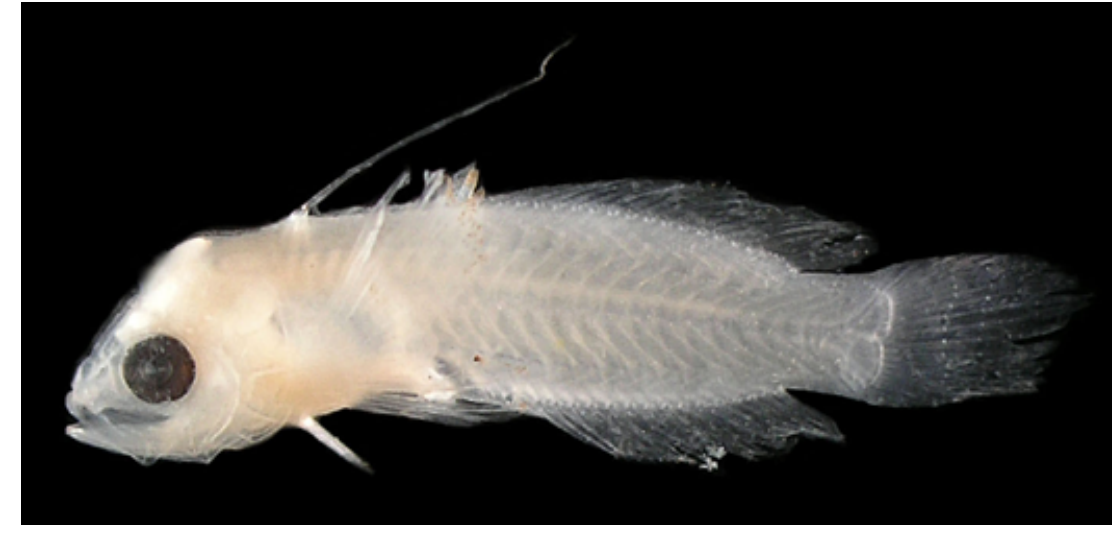

Figura 106 - B: DZUFRJ 7480; Flexão; CP 7,0 mm.

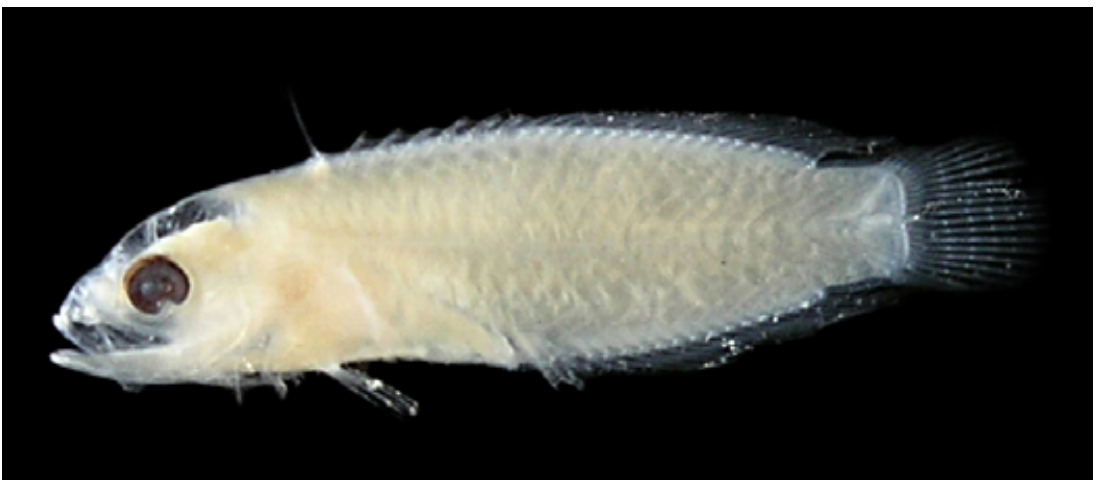

Figura 106 - C: DZUFRJ 22484; Pós-flexão; CP 9,2 mm.

Tamanho: pré-flexão 2,2-4,0 mm; flexão 4,5-7,0 mm; pós-flexão 8,5-9,2 mm.

Habitat: espécie marinha, demersal, associada a formações coralinas. Ocorre em águas tropicais até $61 \mathrm{~m}$ de profundidade.

Nome vulgar: Sabãozinho do alto. 


\section{Georreferenciamento}

\begin{tabular}{|c|c|c|c|c|c|c|c|c|}
\hline DZUFRJ & Latitude (S) & Longitude (W) & Data & $\begin{array}{l}\text { Tipo de } \\
\text { arrasto }\end{array}$ & \begin{tabular}{|c} 
Profundidade \\
de coleta
\end{tabular} & Rede & $\begin{array}{c}\text { Malha } \\
(\mu \mathrm{m})\end{array}$ & $\begin{array}{l}N^{\circ} \text {. de } \\
\text { inds. }\end{array}$ \\
\hline 354 & $22^{\circ} 42^{\prime} 06,0^{\prime \prime}$ & $040^{\circ} 14^{\prime} 26,0^{\prime \prime}$ & 19/05/2002 & oblíquo & $50 \mathrm{~m}$ & bongô & 330 & 1 \\
\hline 365 & $22^{\circ} 41^{\prime} 54,7^{\prime \prime}$ & $040^{\circ} 14^{\prime} 04,5^{\prime \prime}$ & $16 / 05 / 2002$ & oblíquo & $1.000 \mathrm{~m}$ & cilíndrico-cônica & 500 & 1 \\
\hline 457 & $22^{\circ} 33^{\prime} 37,0^{\prime \prime}$ & $040^{\circ} 19^{\prime} 10,0^{\prime \prime}$ & $17 / 05 / 2002$ & oblíquo & $50 \mathrm{~m}$ & bongô & 500 & 1 \\
\hline 1190 & $22^{\circ} 07^{\prime} 29,0^{\prime \prime}$ & $039^{\circ} 06^{\prime} 23,5^{\prime \prime}$ & $10 / 05 / 2002$ & oblíquo & $1.000 \mathrm{~m}$ & cilíndrico-cônica & 500 & 1 \\
\hline 5397 & $22^{\circ} 32^{\prime} 50,0^{\prime \prime}$ & $040^{\circ} 04^{\prime} 09,9^{\prime \prime}$ & 06/11/2001 & oblíquo & $1.000 \mathrm{~m}$ & cilíndrico-cônica & 500 & 1 \\
\hline 5398 & $22^{\circ} 32^{\prime} 50,0^{\prime \prime}$ & $040^{\circ} 04^{\prime} 09,9^{\prime \prime}$ & $06 / 11 / 2001$ & oblíquo & $1.000 \mathrm{~m}$ & cilíndrico-cônica & 500 & 1 \\
\hline 7482 & $21^{\circ} 54^{\prime} 36,5^{\prime \prime}$ & $039^{\circ} 45^{\prime} 20,0^{\prime \prime}$ & $10 / 10 / 2001$ & oblíquo & $1.000 \mathrm{~m}$ & cilíndrico-cônica & 500 & 1 \\
\hline 7485 & $21^{\circ} 54^{\prime} 36,5^{\prime \prime}$ & $039^{\circ} 45^{\prime} 20,0^{\prime \prime}$ & 10/10/2001 & oblíquo & $1.000 \mathrm{~m}$ & cilíndrico-cônica & 500 & 1 \\
\hline 7484 & $21^{\circ} 53^{\prime} 10,4^{\prime \prime}$ & $039^{\circ} 45^{\prime} 49,9^{\prime \prime}$ & $10 / 10 / 2001$ & oblíquo & $1.000 \mathrm{~m}$ & cilíndrico-cônica & 500 & 1 \\
\hline 7481 & $21^{\circ} 53^{\prime} 10,4^{\prime \prime}$ & $039^{\circ} 45^{\prime} 49,9^{\prime \prime}$ & $10 / 10 / 2001$ & oblíquo & $1.000 \mathrm{~m}$ & cilíndrico-cônica & 500 & 1 \\
\hline 7480 & $21^{\circ} 53^{\prime} 10,4^{\prime \prime}$ & $039^{\circ} 45^{\prime} 49,9^{\prime \prime}$ & $10 / 10 / 2001$ & oblíquo & $1.000 \mathrm{~m}$ & cilíndrico-cônica & 500 & 1 \\
\hline 7486 & $21^{\circ} 58^{\prime} 31,0^{\prime \prime}$ & 039०50'29,7"' & 10/10/2001 & oblíquo & $1.000 \mathrm{~m}$ & cilíndrico-cônica & 500 & 1 \\
\hline 7483 & $21^{\circ} 58^{\prime} 31,0^{\prime \prime}$ & $039^{\circ} 50^{\prime 29,7 "}$ & $10 / 10 / 2001$ & oblíquo & $1.000 \mathrm{~m}$ & cilíndrico-cônica & 500 & 2 \\
\hline 22188 & $22^{\circ} 37^{\prime} 21,9^{\prime \prime}$ & $040^{\circ} 02^{\prime} 42,5^{\prime \prime}$ & $08 / 12 / 2002$ & vertical & $0-50 m$ & cilíndrico-cônica & 200 & 1 \\
\hline 22485 & $22^{\circ} 43^{\prime} 50,4^{\prime \prime}$ & $040^{\circ} 02^{\prime} 42,5^{\prime \prime}$ & $07 / 12 / 2002$ & vertical & $0-50 m$ & cilíndrico-cônica & 200 & 1 \\
\hline
\end{tabular}

Referências: Figueiredo \& Menezes, 1980; Watson, 1996c; Heemstra \& Randall, 2002; Richards et al., 2006; Fahay, 2007. 


\section{Família Symphysanodontidae}

A família Symphysanodontidae é marinha e ocorre nos oceanos Atlântico, Índico e Pacífico. Compreende um gênero com seis espécies. Os adultos são pequenos, podendo ocorrer desde 80 a $700 \mathrm{~m}$ de profundidade.

O gênero Symphysanodon foi considerado por vários autores como membro das famílias Acropomatidae, Lutjanidae ou Serranidae devido a presença de espinhos muito desenvolvidos na cabeça, porém não apresentava características específicas dessas famílias. Os representantes desse gênero possuem o corpo lateralmente comprimido, cabeça grande e larga e olhos redondos. O intestino alcança mais de $50 \%$ do comprimento padrão da larva. As espécies podem ser separadas pelo padrão dos espinhos cefálicos, pela pigmentação e, principalmente, pelas características merísticas dos elementos das nadadeiras.

No Brasil essa família nunca tinha sido registrada, sendo uma nova ocorrência. Nesse estudo é contemplada a espécie Symphysanodon sp. 


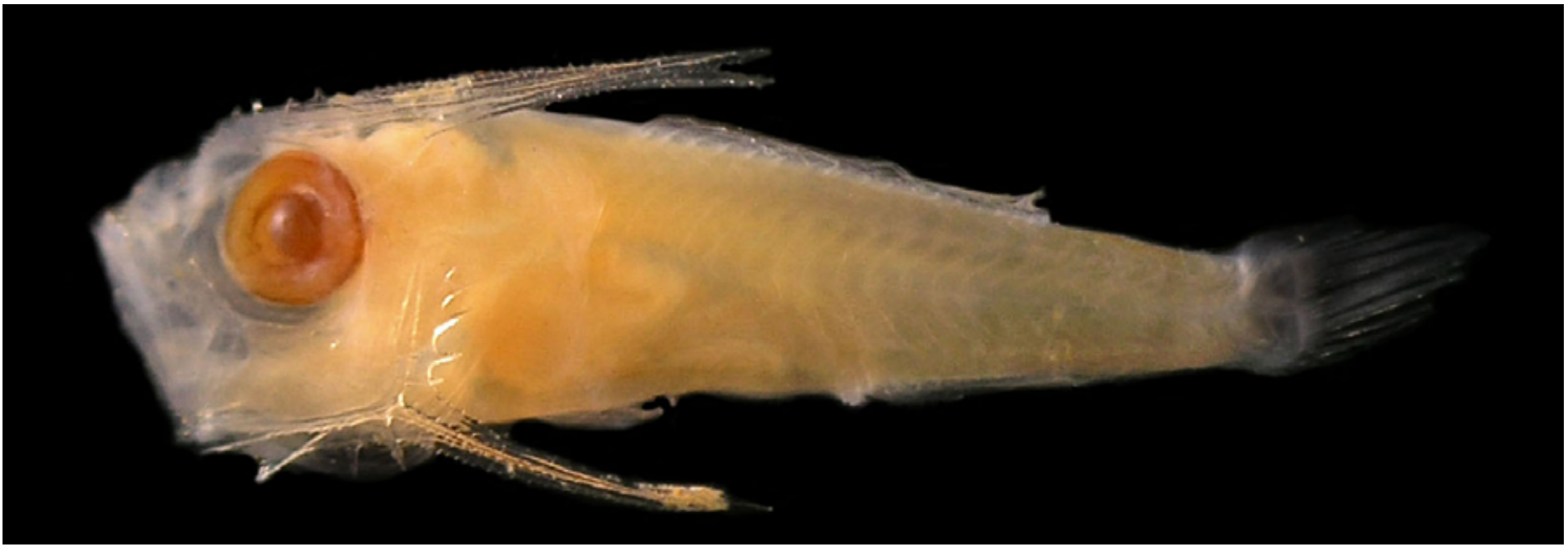

Figura 107 - A: Symphysanodon sp. DZUFRJ 21382; Pós-flexão; CP 7,8 mm.

\section{Symphysanodon sp.}

As larvas de Symphysanodon possuem o corpo lateralmente comprimido, cabeça grande e larga, e olhos redondos. São caracterizadas pelos grandes pares de espinhos serriIhados frontais na cabeça e espinhos menores na região do pré-opérculo. No estágio de pós-flexão, o intestino alcança mais de $50 \%$ do comprimento padrão da larva. Nadadeira dorsal: VIII,11; nadadeira anal: III,7. As larvas encontradas nesse estudo estavam com pigmentação pouco preservada, mas foi possível visualizar alguns melanóforos nas bases das nadadeiras dorsal e anal, além do

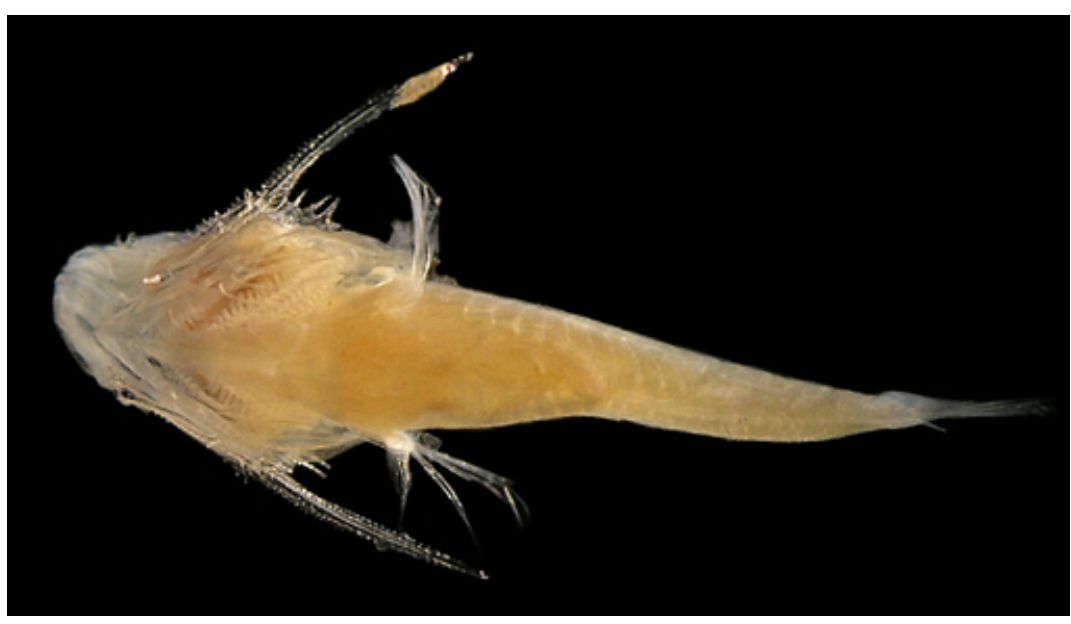

Figura 107 - B: Vista ventral dos espinhos da cabeça. pedúnculo caudal (dorsal e ventralmente). Número total de miômeros: 25.

Tamanho: pós-flexão 7,6-8,8 mm.

Habitat: vive associada ao fundo e é encontrada ao longo da plataforma continental e talude continental superior ou ainda ao redor de ilhas.

\section{Georreferenciamento}

\begin{tabular}{|c|c|c|c|c|c|c|c|c|}
\hline DZUFRJ & Latitude (S) & Longitude (W) & Data & $\begin{array}{c}\text { Tipo de } \\
\text { arrasto }\end{array}$ & $\begin{array}{c}\text { Profundidade } \\
\text { de coleta }\end{array}$ & Rede & $\begin{array}{c}\text { Malha } \\
\text { ( } \boldsymbol{\mu m})\end{array}$ & $\begin{array}{c}\text { No. de } \\
\text { inds. }\end{array}$ \\
\hline 21382 & $22^{\circ} 32^{\prime} 50,0^{\prime \prime}$ & $040^{\circ} 04^{\prime} 09,9^{\prime \prime}$ & $06 / 11 / 2001$ & oblíquo & $1.000 \mathrm{~m}$ & cilíndrico-cônica & 500 & 2 \\
\hline
\end{tabular}

Referências: Leis \& Trnski, 2000; Menezes et al., 2003; Anderson, 2003; Anderson \& Springer, 2005; Hardy, 2006b; Fahay, 2007; Froese \& Pauly, 2014. 


\section{Família Apogonidae}

A família Apogonidae ocorre nos oceanos Atlântico, Índico e Pacífico. Compreende aproximadamente 23 gêneros e 273 espécies. Os membros da família Apogonidae vivem associados a formações coralinas e ocorrem em mares tropicais e subtropicais, sendo que algumas espécies vivem em água doce e salobra. Possuem as nadadeiras dorsais separadas, corpo alto na porção anterior e o pedúnculo caudal é longo e estreito. A identificação das espécies se baseia principalmente no número de rastros branquiais, número de raios da nadadeira peitoral e no padrão de pigmentação.

No Brasil já foram identificadas oito espécies nas fases de larva e adulto. Nesse estudo são contempladas as espécies Apogon sp. e Astrapogon sp. 


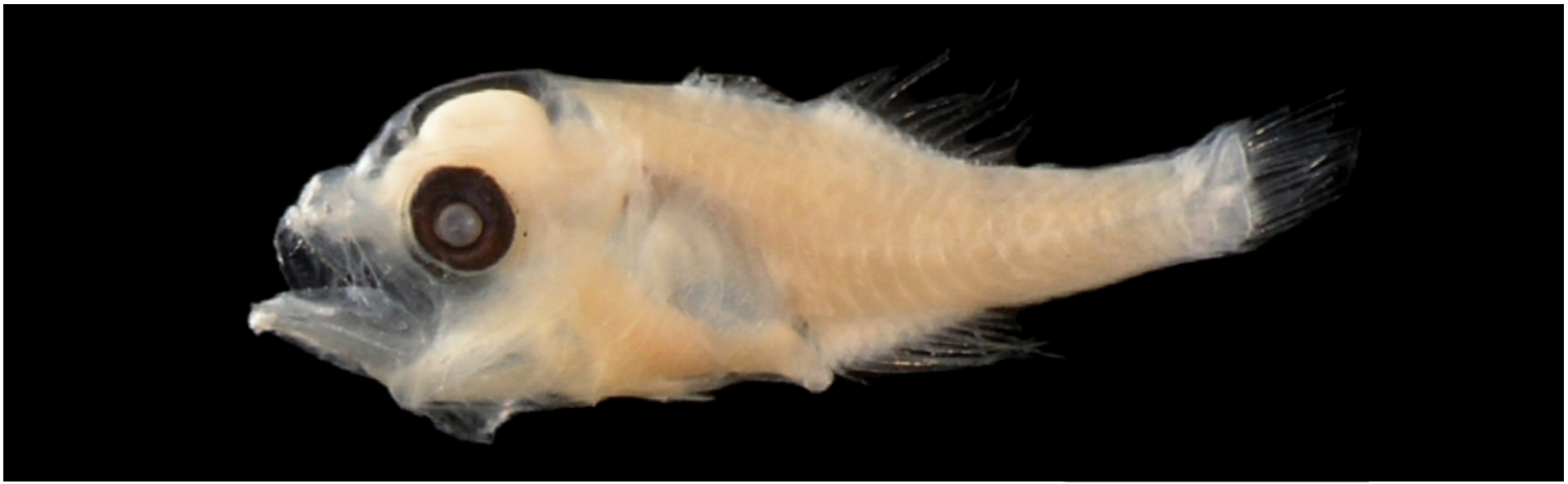

Figura 108 - A: Apogon sp. A. DZUFRJ 13958; Flexão; CP 3,5 mm.

\section{Apogon sp.}

As larvas de Apogon possuem a margem do pré-opérculo pouco serrilhada. Têm nadadeiras dorsais espaçadas, pouca pigmentação espalhada pelo corpo e nos raios das nadadeiras, principalmente na pélvica. A pigmentação se concentra na cabeça e próximo aos olhos e opérculo, além de pequenas manchas na base das

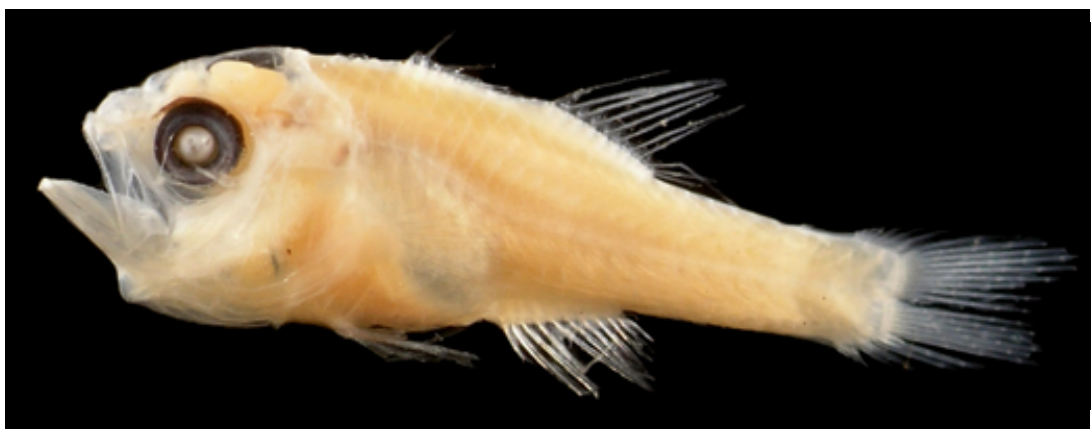

Figura 108 - B: DZUFRJ 14132; Pós-flexão; CP 6,2 mm. nadadeiras dorsal e caudal. Esse padrão de pigmentação e a contagem dos rastros branquiais possibilitam a identificação das espécies. A pigmentação das larvas utilizadas nesse estudo estava pouco preservada, o que impossibilitou a identificação até espécie. Número total de miômeros: 24 . No Brasil, foram registradas as espécies: Apogon americanus Castelnau, 1855; Apogon planifrons Longley \& Hildebrand, 1940; Apogon pseudomaculatus Longley, 1932 e Apogon quadrisquamatus Longley, 1934.

Tamanho: flexão 3,5 mm; pós-flexão 6,0-6,5 mm.

Habitat: todas as espécies de Apogon são demersais, com hábitos noturnos. São tipicamente associadas a formações coralinas e cavernas.

\section{Georreferenciamento}

\begin{tabular}{|c|c|c|c|c|c|c|c|c|}
\hline DZUFRJ & Latitude (S) & Longitude (W) & Data & $\begin{array}{c}\text { Tipo de } \\
\text { arrasto }\end{array}$ & $\begin{array}{c}\text { Profundidade } \\
\text { de coleta }\end{array}$ & Rede & $\begin{array}{c}\text { Malha } \\
\text { ( } \boldsymbol{\mu m})\end{array}$ & $\begin{array}{c}\mathbf{N}^{\circ} \text {. de } \\
\text { inds. }\end{array}$ \\
\hline 378 & $22^{\circ} 33^{\prime} 45,8^{\prime \prime}$ & $040^{\circ} 13^{\prime} 22,9^{\prime \prime}$ & $17 / 05 / 2002$ & oblíquo & $800 \mathrm{~m}$ & cilíndrico-cônica & 500 & 1 \\
\hline 389 & $22^{\circ} 37^{\prime} 35,5^{\prime \prime}$ & $040^{\circ} 09^{\prime} 32,8^{\prime \prime}$ & $16 / 05 / 2002$ & oblíquo & $1.000 \mathrm{~m}$ & cilíndrico-cônica & 500 & 1 \\
\hline 400 & $22^{\circ} 31^{\prime} 27,0^{\prime \prime}$ & $040^{\circ} 16^{\prime} 56,0^{\prime \prime}$ & $17 / 05 / 2002$ & oblíquo & $600 \mathrm{~m}$ & cilíndrico-cônica & 500 & 1 \\
\hline 401 & $22^{\circ} 41^{\prime} 54,7^{\prime \prime}$ & $040^{\circ} 14^{\prime} 04,5^{\prime \prime}$ & $16 / 05 / 2002$ & oblíquo & $1.000 \mathrm{~m}$ & cilíndrico-cônica & 500 & 1 \\
\hline 404 & $22^{\circ} 33^{\prime} 47,7^{\prime \prime}$ & $040^{\circ} 12^{\prime} 20,5^{\prime \prime}$ & $17 / 05 / 2002$ & oblíquo & $50 \mathrm{~m}$ & bongô & 330 & 2 \\
\hline
\end{tabular}

Referências: Figueiredo \& Menezes, 1980; Lara, 2006a; Fahay, 2007. 


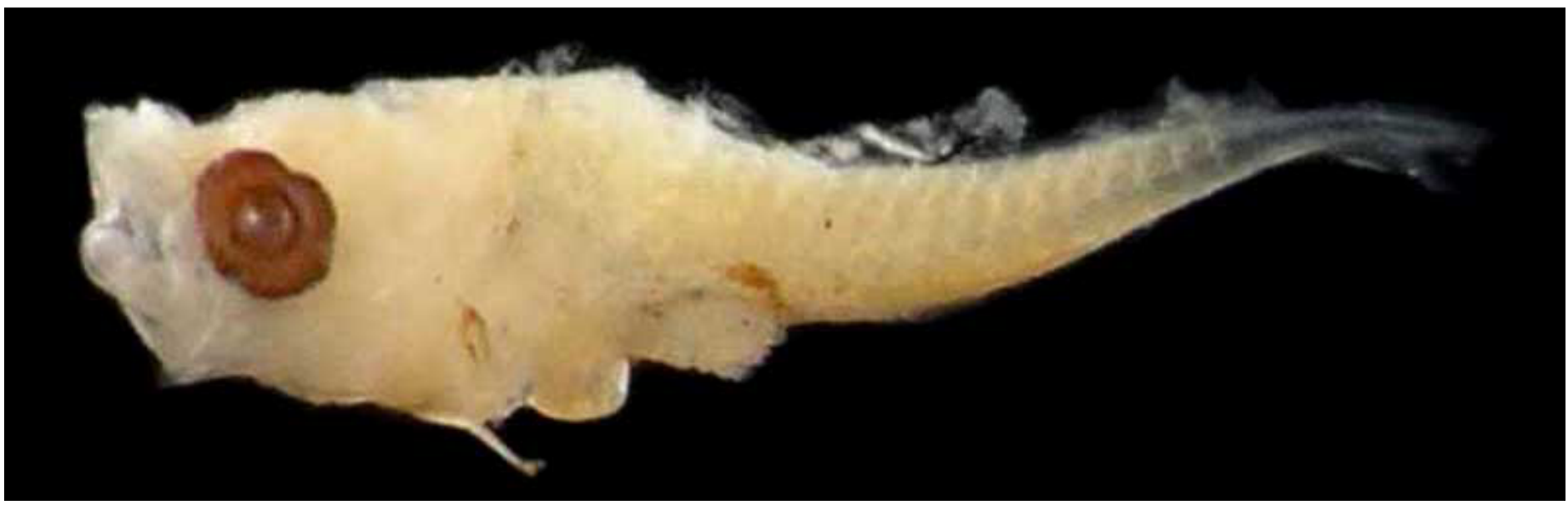

Figura 109 - A: Astrapogon sp. DZUFRJ 403; Pré-flexão; CP 2,4 mm.

\section{Astrapogon sp.}

As larvas deste gênero tem a margem do pré-opérculo lisa. A partir da flexão as larvas de Astrapogon possuem melanóforos grandes e estrelados na cabeça e espalhados pelo corpo, diferente do observado em Apogon. A membrana entre os espinhos das nadadeiras dorsal e pélvica é pigmentada. Com o desenvolvimento larval, os melanóforos tendem a se espalhar por todo corpo, tornando-se mais intensos. A pigmentação das lar-

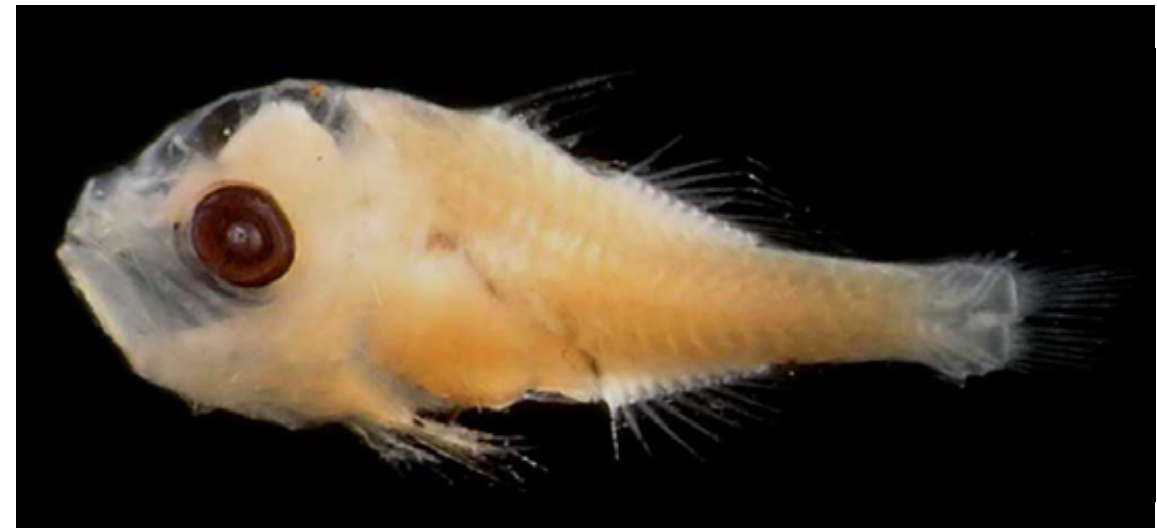

Figura 109 - B: DZUFRJ 1696; Flexão; CP 4,0 mm. vas em pré-flexão e flexão não estava bem preservada, o que impossibilitou a identificação até espécie. Número total de miômeros: 24.

Tamanho: pré-flexão 2,4-3,0 mm; flexão 4,0-5,5 mm.

Habitat: todas as espécies de Astapogon são demersais e tipicamente associadas a formações coralinas e cavernas.

Nome vulgar: Totó pintadinho.

\section{Georreferenciamento}

\begin{tabular}{|c|c|c|c|c|c|c|c|c|}
\hline DZUFR & Latitude (S) & Longitude (W) & Data & $\begin{array}{c}\text { Tipo de } \\
\text { arrasto }\end{array}$ & $\begin{array}{c}\text { Profundidade } \\
\text { de coleta }\end{array}$ & Rede & $\begin{array}{c}\text { Malha } \\
\text { ( } \boldsymbol{\mu m})\end{array}$ & $\begin{array}{c}\mathbf{N}^{\circ} \text {. de } \\
\text { inds. }\end{array}$ \\
\hline 386 & $22^{\circ} 33^{\prime} 37,0^{\prime \prime}$ & $040^{\circ} 19^{\prime} 10,0^{\prime \prime}$ & $17 / 05 / 2002$ & oblíquo & $50 \mathrm{~m}$ & bongô & 500 & 2 \\
\hline 402 & $22^{\circ} 33^{\prime} 47,7^{\prime \prime}$ & $040^{\circ} 12^{\prime} 20,5^{\prime \prime}$ & $17 / 05 / 2002$ & oblíquo & $50 \mathrm{~m}$ & bongô & 500 & 2 \\
\hline 403 & $22^{\circ} 34^{\prime} 05,0^{\prime \prime}$ & $040^{\circ} 19^{\prime} 40,0^{\prime \prime}$ & $17 / 05 / 2002$ & oblíquo & $600 \mathrm{~m}$ & cilíndrico-cônica & 500 & 3 \\
\hline 1230 & $22^{\circ} 02^{\prime} 30,0^{\prime \prime}$ & $039^{\circ} 49^{\prime} 41,2^{\prime \prime}$ & $12 / 05 / 2002$ & oblíquo & $1.000 \mathrm{~m}$ & cilíndrico-cônica & 500 & 1 \\
\hline 1345 & $22^{\circ} 06^{\prime} 52,3^{\prime \prime}$ & $039^{\circ} 48^{\prime} 46,2^{\prime \prime}$ & $11 / 05 / 2002$ & oblíquo & até a termoclina & bongô & 330 & 1 \\
\hline
\end{tabular}

Referências: Figueiredo \& Menezes, 1980; Lara, 2006a; Fahay, 2007. 


\section{Família Pomatomidae}

A família Pomatomidae é mono-específica representada por Pomatomus saltatrix. Essa espécie é pelágica, encontrada em diversas áreas do mundo, exceto no Pacífico leste. Utiliza águas costeiras e regiões estuarinas para reprodução. 


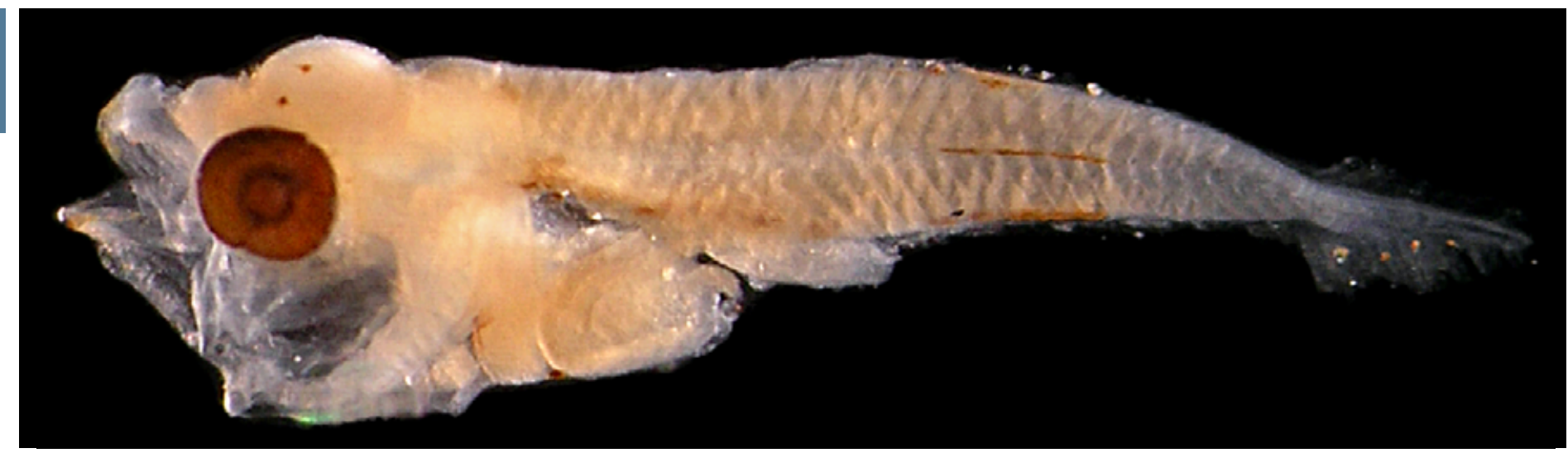

Figura 110 - A: Pomatomus saltatrix. DZUFRJ 5498; Pré-flexão; CP 3,4 mm.

\section{Pomatomus saltatrix (Linnaeus, 1766)}

As larvas possuem o corpo fusiforme (26 miômeros). O intestino é curto, alcançando aproximadamente $50 \%$ do comprimento padrão. Pequenos espinhos são encontrados na margem posterior do pré-opérculo. Essa espécie é caracterizada pelos melanóforos presentes

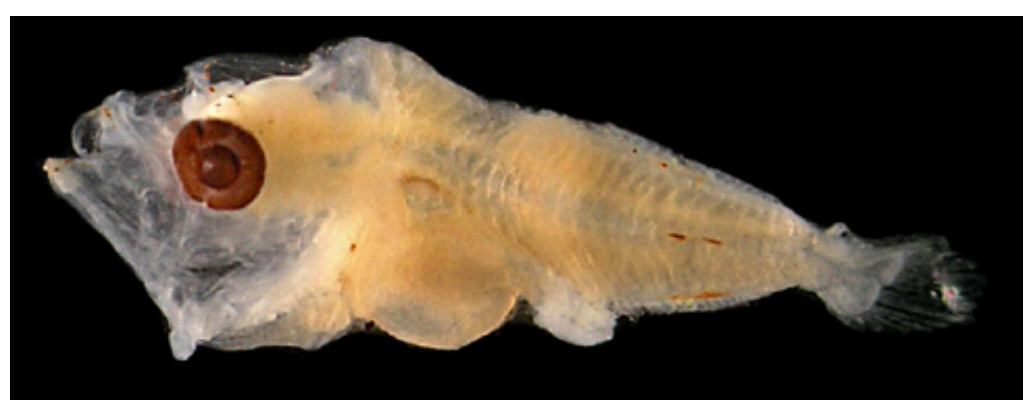

Figura 110 - B: DZUFRJ 7146; Flexão; CP 4,1 mm. na cabeça, nas regiões dorsal, ventral e na linha lateral do corpo, desde a pré-flexão até a pós-flexão. Há pigmentos também sobre a massa visceral, logo abaixo da base da nadadeira peitoral, que ficam menos intensos com o desenvolvimento larval. As duas nadadeiras dorsais são separadas, com VII-VIII, 23-28. A nadadeira anal é formada por II-III, 23-27.

Tamanho: pré-flexão 2,2-4,0 mm; flexão 4,1-4,2 mm.

Habitat: espécie costeira, pelágica, podendo ser encontrada em águas da plataforma continental, em profundidades de até 200 m, além de baías e estuários.

Nome vulgar: Enchova.

\section{Georreferenciamento}

\begin{tabular}{|c|c|c|c|c|c|c|c|c|}
\hline DZUFRJ & Latitude (S) & Longitude (W) & Data & $\begin{array}{l}\text { Tipo de } \\
\text { arrasto }\end{array}$ & $\begin{array}{l}\text { Profundidade } \\
\text { de coleta }\end{array}$ & Rede & $\begin{array}{c}\text { Malha } \\
(\mu \mathrm{m})\end{array}$ & $\begin{array}{l}N^{\circ} \text {. de } \\
\text { inds. }\end{array}$ \\
\hline 5495 & $22^{\circ} 32^{\prime} 49,0^{\prime \prime}$ & $040^{\circ} 04^{\prime} 20,9^{\prime \prime}$ & $07 / 11 / 2001$ & oblíquo & $1.000 \mathrm{~m}$ & cilíndrico-cônica & 500 & 1 \\
\hline 5496 & $22^{\circ} 31^{\prime} 40,9^{\prime \prime}$ & $040^{\circ} 02^{\prime} 39,6^{\prime \prime}$ & $07 / 11 / 2001$ & oblíquo & $1.000 \mathrm{~m}$ & cilíndrico-cônica & 500 & 10 \\
\hline 5497 & $22^{\circ} 32^{\prime} 50,0^{\prime \prime}$ & $040^{\circ} 04^{\prime} 09,9^{\prime \prime}$ & $06 / 11 / 2001$ & oblíquo & $1.000 \mathrm{~m}$ & cilíndrico-cônica & 500 & 2 \\
\hline 5498 & $22^{\circ} 31^{\prime} 40,9^{\prime \prime}$ & $040^{\circ} 02^{\prime} 39,6^{\prime \prime}$ & $07 / 11 / 2001$ & oblíquo & $1.000 \mathrm{~m}$ & cilíndrico-cônica & 500 & 3 \\
\hline 5538 & $22^{\circ} 31^{\prime} 58,9^{\prime \prime}$ & $040^{\circ} 02^{\prime} 53,4^{\prime \prime}$ & $07 / 11 / 2001$ & oblíquo & $1.000 \mathrm{~m}$ & cilíndrico-cônica & 500 & 1 \\
\hline 5543 & $22^{\circ} 32^{\prime} 49,0^{\prime \prime}$ & $040^{\circ} 04^{\prime} 20,9^{\prime \prime}$ & $07 / 11 / 2001$ & oblíquo & $1.000 \mathrm{~m}$ & cilíndrico-cônica & 500 & 3 \\
\hline 5548 & $22^{\circ} 31^{\prime} 58,9^{\prime \prime}$ & $040^{\circ} 02^{\prime} 53,4^{\prime \prime}$ & $07 / 11 / 2001$ & oblíquo & $1.000 \mathrm{~m}$ & cilíndrico-cônica & 500 & 1 \\
\hline 7374 & 215'10,4" & $039^{\circ} 45^{\prime} 49,9^{\prime \prime}$ & 10/10/2001 & oblíquo & $1.000 \mathrm{~m}$ & cilíndrico-cônica & 500 & 1 \\
\hline 7375 & 2158'31,0" & 03950'29,7" & 10/10/2001 & oblíquo & $1.000 \mathrm{~m}$ & cilíndrico-cônica & 500 & 2 \\
\hline 7376 & $21^{\circ} 54 ' 36,5^{\prime \prime}$ & $039^{\circ} 45^{\prime} 20,0^{\prime \prime}$ & 10/10/2001 & oblíquo & $1.000 \mathrm{~m}$ & cilíndrico-cônica & 500 & 1 \\
\hline 7377 & $21^{\circ} 54^{\prime} 36,5^{\prime \prime}$ & $039^{\circ} 45^{\prime} 20,0^{\prime \prime}$ & $10 / 10 / 2001$ & oblíquo & $1.000 \mathrm{~m}$ & cilíndrico-cônica & 500 & 1 \\
\hline 7378 & $21^{\circ} 53^{\prime} 10,4^{\prime \prime}$ & $039^{\circ} 45^{\prime} 49,9^{\prime \prime}$ & $10 / 10 / 2001$ & oblíquo & $1.000 \mathrm{~m}$ & cilíndrico-cônica & 500 & 1 \\
\hline
\end{tabular}

Referências: Collette, 2002a; Ditty, 2006d; Fahay, 2007. 


\section{Família Carangidae}

A família Carangidae é tipicamente marinha e ocorre nos oceanos Atlântico, Índico e Pacífico. Compreende aproximadamente 32 gêneros com 140 espécies. As espécies podem ser pelágicas ou demersais e muitas possuem importância comercial.

As larvas dessa família têm o formato do corpo variando desde fusiforme a alto e discoide. Apresentam três espinhos na nadadeira anal, sendo dois destacados. Possuem muitos espinhos no pré-opérculo, crista supraoccipital mediana desenvolvida e cristas supraoculares. A combinação dos caracteres merísticos e o padrão de pigmentação das larvas são importantes para a identificação das espécies.

No Brasil já foram identificadas 35 espécies nas fases de larva e adulto. Nesse estudo são contempladas as espécies Caranx sp., Decapterus punctatus, Selar crumenophthalmus, Seriola dumerili e Trachurus lathami. 


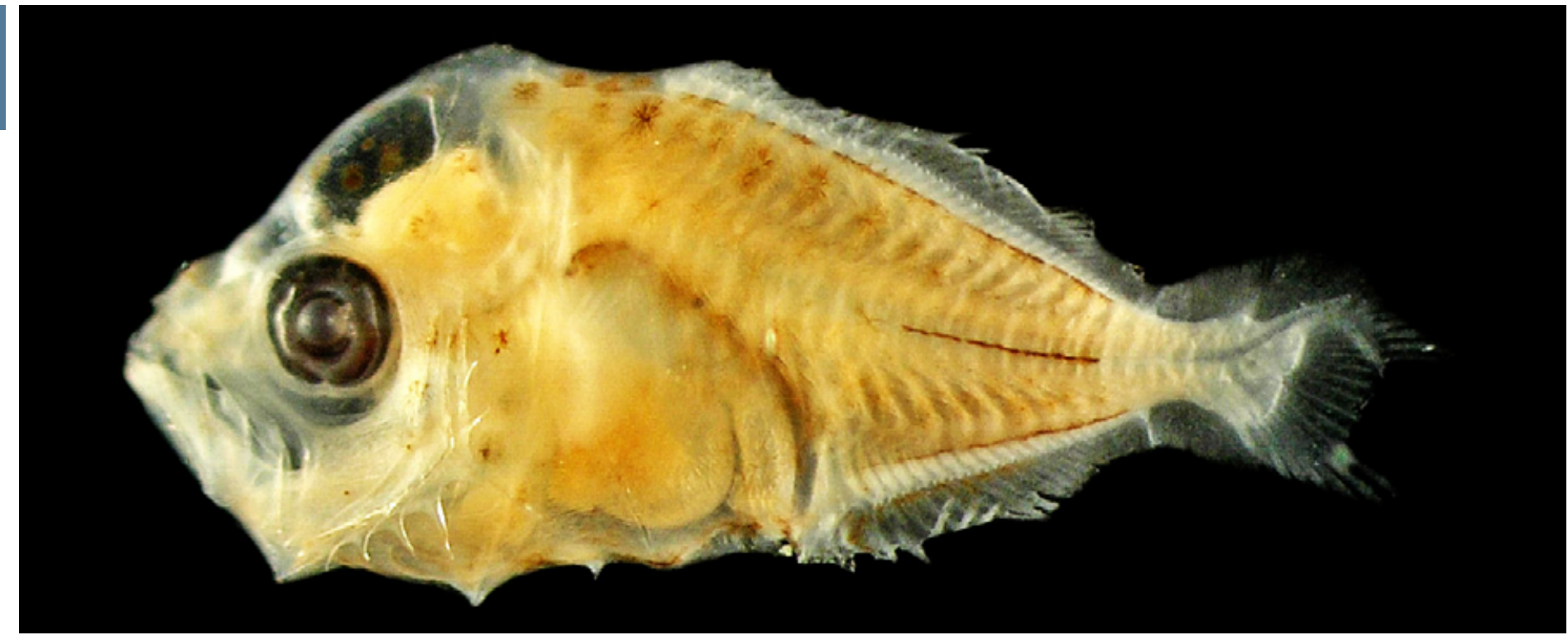

Figura 111: Caranx sp. DZUFRJ 30830; Flexão; CP 4,7 mm.

\section{Caranx sp.}

A identificação das larvas do gênero Caranx ainda é um pouco incerta. As espécies podem ser diferenciadas pelo padrão de pigmentação do corpo e da cabeça. As larvas em pré-flexão são dificilmente identificadas além de gênero, pois ainda não possuem as características necessárias para a identificação desenvolvidas. As larvas em flexão possuem crista supraoccipital, espinho pré-opercular simples, corpo mais alto, forte pigmentação dorso e ventro-lateral, sendo que a linha dorsal estende-se até a nuca. As larvas de Caranx não possuem elementos das nadadeiras alongados. Na área de estudo não estava com a pigmentação preservada, nem os raios das nadadeiras estavam formados, dificultando a identificação até espécie. Número total de miômeros: 24. No Brasil já foram registradas as espécies Caranx crysos (Mitchill, 1815), Caranx hippos (Linnaeus, 1766), Caranx latus Agassiz, 1831 e Caranx lugubris Poey, 1860.

Tamanho: flexão 4,0 mm.

Habitat: todas as espécies de Caranx são pelágicas e ocorrem em regiões costeiras ou oceânicas. Os adultos são encontrados em áreas além da quebra da plataforma ou associados a formações coralinas ou ilhas.

\section{Georreferenciamento}

\begin{tabular}{|c|c|c|c|c|c|c|c|c|}
\hline DZUFR & Latitude (S) & Longitude (W) & Data & $\begin{array}{c}\text { Tipo de } \\
\text { arrasto }\end{array}$ & $\begin{array}{c}\text { Profundidade } \\
\text { de coleta }\end{array}$ & Rede & Malha ( $\boldsymbol{\mu m})$ & $\mathbf{N}^{\circ}$. de inds. \\
\hline 1225 & $22^{\circ} 28,58^{\prime}$ & $039^{\circ} 55,72^{\prime}$ & $16 / 06 / 2003$ horizontal & superfície & nêuston & 500 & 1 \\
\hline
\end{tabular}

Referências: Menezes \& Figueiredo, 1980; Watson et al., 1996; Smith-Vaniz, 2002; Ditty et al., 2004; Laroche et al., 2006; Fahay, 2007. 


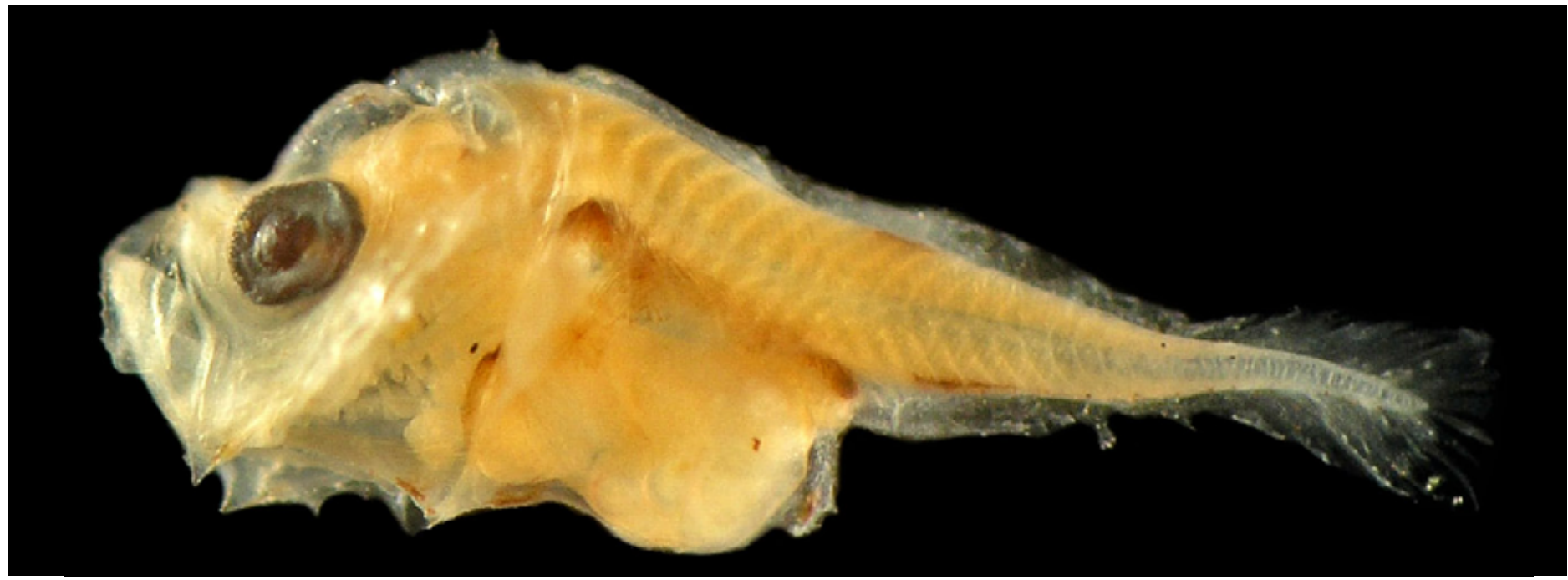

Figura 112 - A: Decapterus punctatus. DZUFRJ 24979; Pré-flexão; CP 2,9mm.

\section{Decapterus punctatus (Cuvier, 1829)}

As larvas pertencentes a essa espécie possuem o corpo moderadamente alto, com cabeça de tamanho moderado a grande e focinho côncavo. A crista supraoccipital é bem desenvolvida e irregular. Em pré-flexão, a pigmentação dorsal é pouco intensa e concentrada na porção posterior do corpo, a partir da base do segundo espinho da nadadeira dorsal. Na cabeça, as larvas possuem melanóforos dispersos na porção posterior do encéfalo, próximo aos olhos e na ponta da mandíbula. Diferem-se pela pouca quantidade de pigmentos abaixo da massa visceral. Em flexão, a pigmentação torna-se mais intensa e se espalha pelas bases dos espinhos e raios das nadadeiras dorsal e anal, além da linha lateral. Na cabeça a pigmentação se espalha para a porção anterior do encéfalo, no

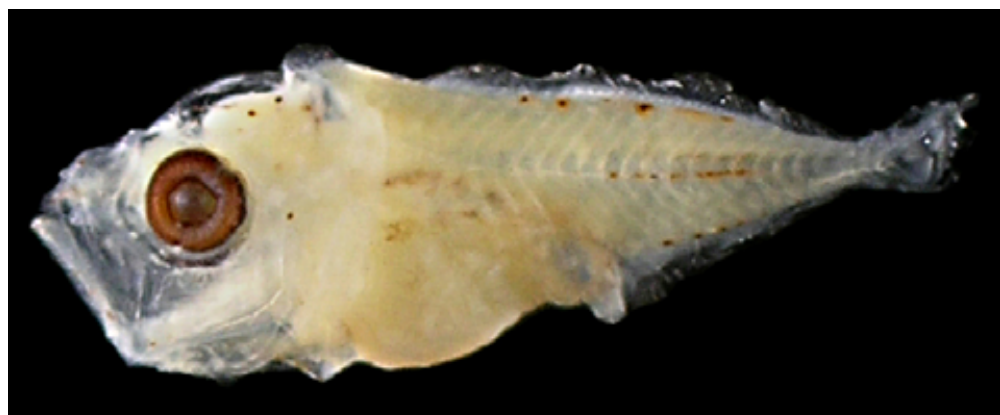

Figura 112 - B: DZUFRJ 366; Flexão; CP 4,8 mm.

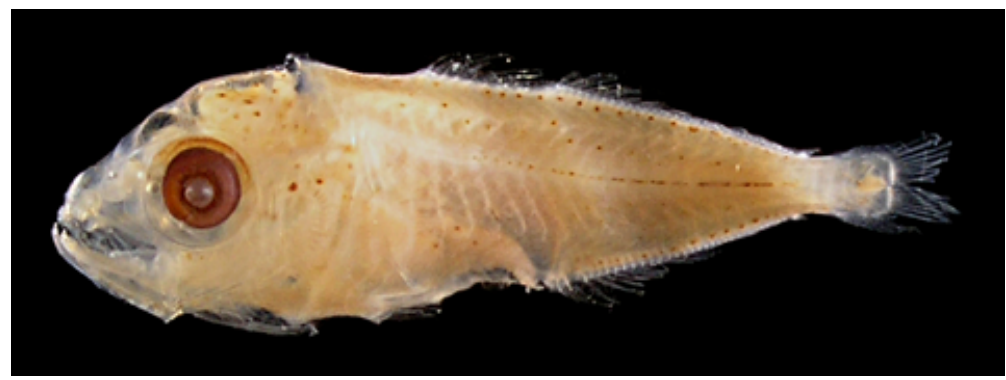

Figura 112 - C: DZUFRJ 7493; Pós-flexão; CP 9,8 mm. cleitro e permanece na mandíbula. No estágio de pós-flexão a crista é reduzida, tendendo a desaparecer com o crescimento e ocorre o isolamento do último raio da nadadeira dorsal. A pigmentação na cabeça concentra-se no encéfalo, próximo aos olhos e no cleitro. No abdome, vários melanóforos aparecem na parede da vesícula gasosa, peritôneo e intestino. Os pigmentos espalham-se ao longo do corpo e entre as linhas mediano-dorsal, ventral e lateral. Essa espécie é muito semelhante a Trachurus lathami, podendo ser separada pela quantidade e posição dos pigmentos na região dorsal do corpo. Número total de miômeros: 25.

Tamanho: pré-flexão 2,3-3,8 mm; flexão 4,5-4,8 mm; pós-flexão 9,8 mm.

Habitat: espécie marinha, pelágica, ocorre em águas subtropicais entre 9 e 90 m de profundidade. Durante o dia os juvenis ocorrem próximo à superfície, descendo para o fundo a noite.

Nome vulgar: Chicharro pintado. 


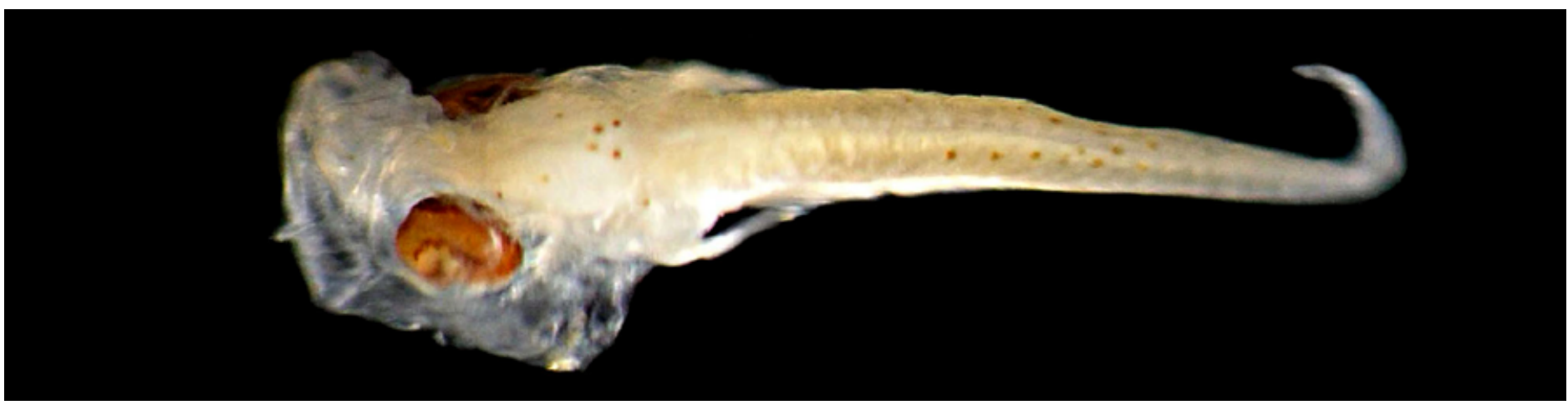

Figura 112 - D: Detalhe da cabeça na pré-flexão.

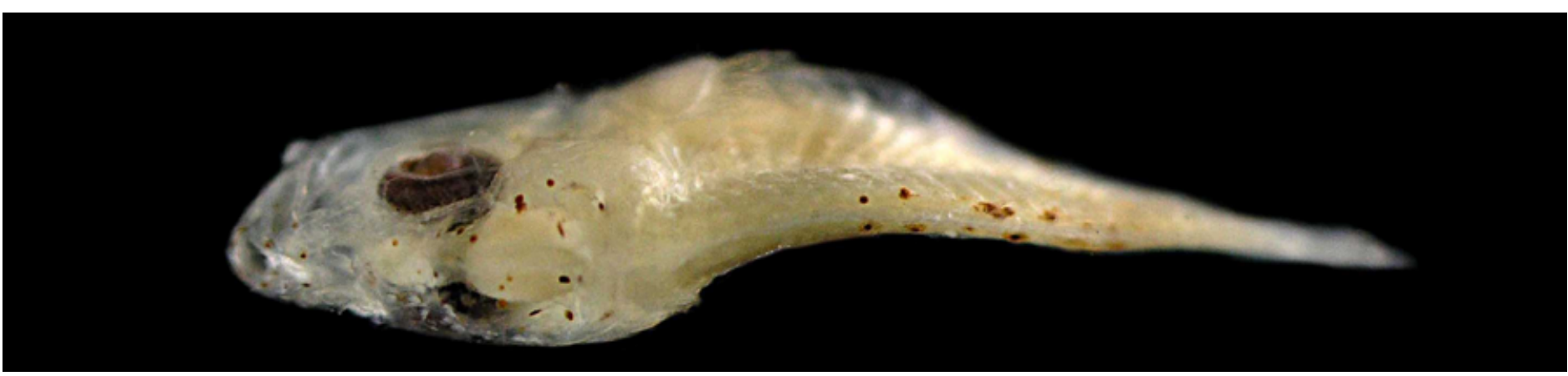

Figura 112 - E: Detalhe da cabeça na flexão.

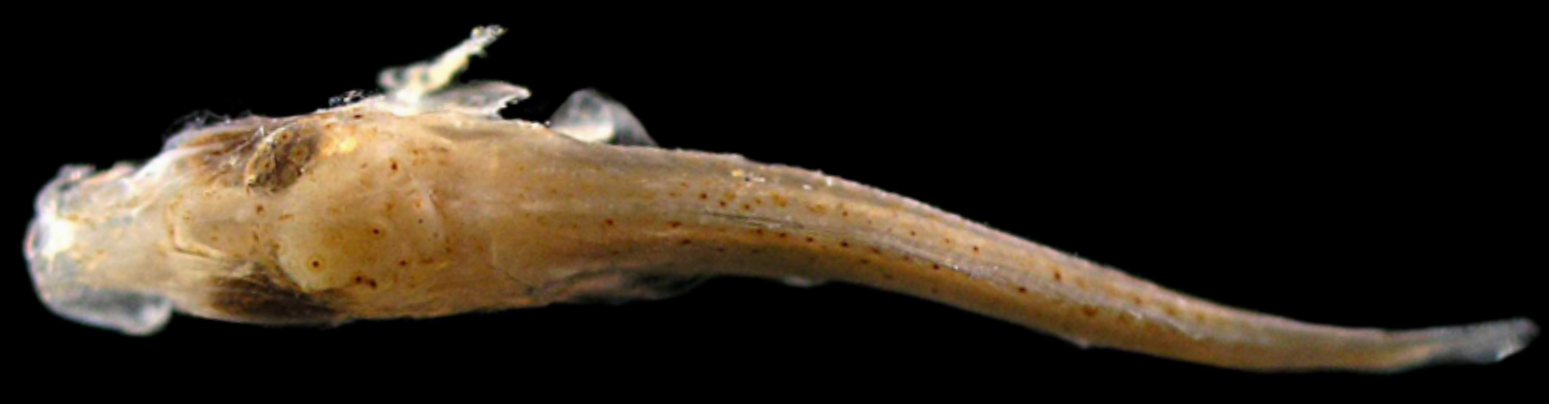

Figura 112 - F: Detalhe da cabeça na pós-flexão.

\section{Georreferenciamento}

\begin{tabular}{|c|c|c|c|c|c|c|c|c|}
\hline DZUFR & Latitude (S) & Longitude (W) & Data & $\begin{array}{c}\text { Tipo de } \\
\text { arrasto }\end{array}$ & $\begin{array}{c}\text { Profundidade } \\
\text { de coleta }\end{array}$ & Rede & $\begin{array}{c}\text { Malha } \\
\text { ( } \boldsymbol{\mu m} \text { ) }\end{array}$ & $\begin{array}{c}\mathbf{N}^{\circ} \text {. de } \\
\text { inds. }\end{array}$ \\
\hline 366 & $22^{\circ} 34^{\prime} 05,0^{\prime \prime}$ & $040^{\circ} 19^{\prime} 40,0^{\prime \prime}$ & $17 / 05 / 2002$ & oblíquo & $600 \mathrm{~m}$ & cilíndrico-cônica & 500 & 3 \\
\hline 2618 & $22^{\circ} 35^{\prime} 66,4^{\prime \prime}$ & $039^{\circ} 46^{\prime} 40,6^{\prime \prime}$ & $06 / 12 / 2002$ & horizontal & superfície & nêuston & 500 & 2 \\
\hline 2623 & $22^{\circ} 35^{\prime} 66,4^{\prime \prime}$ & $039^{\circ} 46^{\prime} 40,6^{\prime \prime}$ & $06 / 12 / 2002$ & horizontal & superfície & nêuston & 500 & 3 \\
\hline 7491 & $21^{\circ} 54^{\prime} 36,5^{\prime \prime}$ & $039^{\circ} 45^{\prime} 20,0^{\prime \prime}$ & $10 / 10 / 2001$ & oblíquo & $1.000 \mathrm{~m}$ & cilíndrico-cônica & 500 & 1 \\
\hline 7493 & $21^{\circ} 58^{\prime} 31,0^{\prime \prime}$ & $039^{\circ} 50^{\prime} 29,7^{\prime \prime}$ & $10 / 11 / 2001$ & oblíquo & $1.000 \mathrm{~m}$ & cilíndrico-cônica & 500 & 1 \\
\hline 7494 & $2^{\circ} 57^{\prime} 10,5^{\prime \prime}$ & $039^{\circ} 43^{\prime} 33,3^{\prime \prime}$ & $09 / 10 / 2001$ & oblíquo & $1.000 \mathrm{~m}$ & cilíndrico-cônica & 500 & 1 \\
\hline
\end{tabular}

Referências: Menezes \& Figueiredo, 1980; Katsuragawa \& Matsuura, 1992; Watson et al., 1996; Smith-Vaniz, 2002; Laroche et al., 2006; Fahay, 2007 


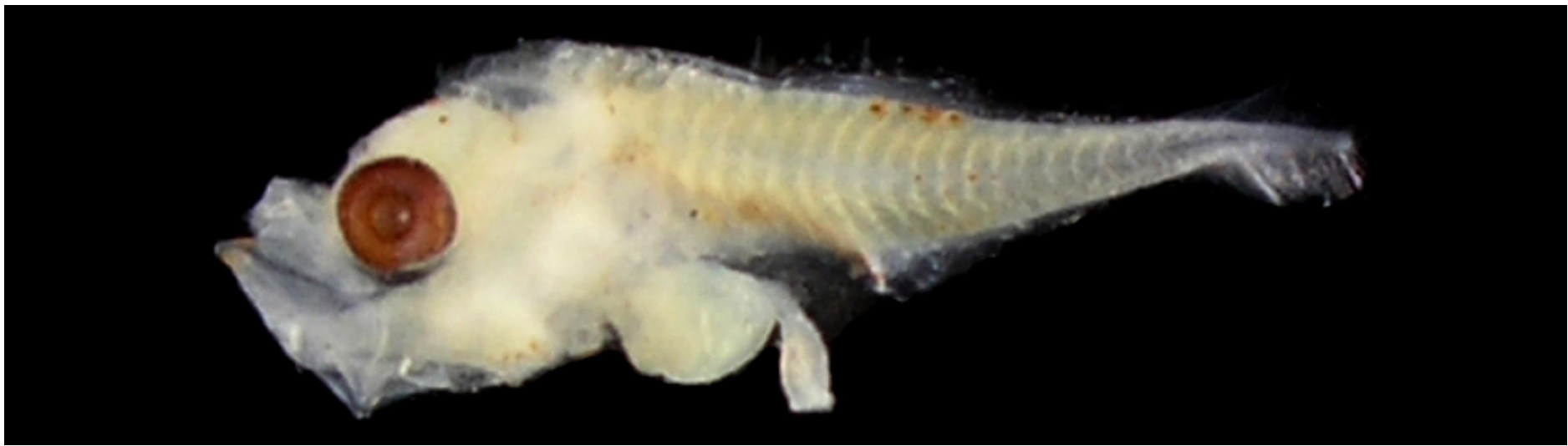

Figura 113 - A: Selar crumenophthalmus. DZUFRJ 476; Pré-flexão; CP 2,3 mm.

\section{Selar}

\section{crumenophthalmus (Bloch, 1793)}

Os representantes dessa espécie são caracterizados pela presença de crista supraoccipital desenvolvida, melanóforos alinhados na região inferior da cauda, no miossepto e pelo pouco número de raios

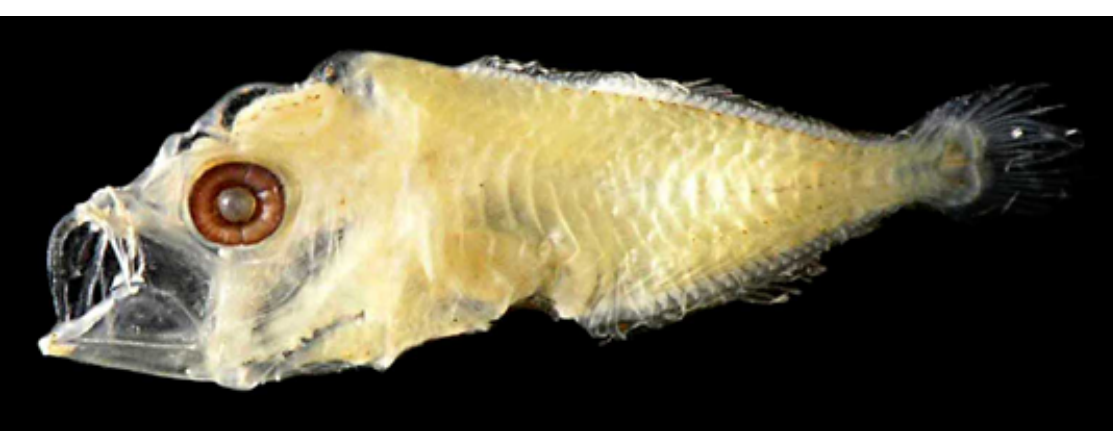

Figura 113 - B: DZUFRJ 477; Flexão; CP 5,0 mm. nas nadadeiras dorsal (VIII-IX, 25-26) e anal (II-III, 21-23). Nos estágios de pré-flexão e flexão, há a presença de poucos melanóforos na cabeça, mandíbula, superfície dorsal da vesícula gasosa e massa visceral. Pigmentos na base da nadadeira pélvica, na margem dorsal (formando uma fileira bilateral) e ventral no corpo, além de pigmentos destacados ao longo da linha lateral e base da notocorda. Número total de miômeros: 24.

Tamanho: pré-flexão 2,3-3,7 mm; flexão 3,8-6,4 mm.

Habitat: espécie marinha, pelágica que vive em grupos muito próximos à costa ou sobre formações coralinas rasas. Ocorre em águas tropicais e subtropicais, até $170 \mathrm{~m}$ de profundidade.

Nome vulgar: Chicharro olho grande.

\section{Georreferenciamento}

\begin{tabular}{|c|c|c|c|c|c|c|c|c|}
\hline DZUFRJ & Latitude (S) & Longitude (W) & Data & $\begin{array}{c}\text { Tipo de } \\
\text { arrasto }\end{array}$ & $\begin{array}{c}\text { Profundidade } \\
\text { de coleta }\end{array}$ & Rede & $\begin{array}{c}\text { Malha } \\
(\boldsymbol{\mu m})\end{array}$ & $\begin{array}{c}\mathbf{N}^{\circ} \text {. de } \\
\text { inds. }\end{array}$ \\
\hline 356 & $22^{\circ} 31^{\prime} 27,0^{\prime \prime}$ & $040^{\circ} 16^{\prime} 56,0^{\prime \prime}$ & $17 / 05 / 2002$ & oblíquo & $600 \mathrm{~m}$ & cilíndrico-cônica & 500 & 1 \\
\hline 363 & $22^{\circ} 38^{\prime} 25,0^{\prime \prime}$ & $040^{\circ} 17^{\prime} 41,0^{\prime \prime}$ & $19 / 05 / 2002$ & oblíquo & $40 \mathrm{~m}$ & bongô & 500 & 3 \\
\hline 364 & $22^{\circ} 33^{\prime} 47,7^{\prime \prime}$ & $040^{\circ} 12^{\prime} 20,5^{\prime \prime}$ & $17 / 05 / 2002$ & oblíquo & $50 \mathrm{~m}$ & bongô & 500 & 4 \\
\hline 476 & $22^{\circ} 37^{\prime} 355^{\prime \prime}$ & $040^{\circ} 09^{\prime} 32,8^{\prime \prime}$ & $16 / 05 / 2002$ & oblíquo & $1.000 \mathrm{~m}$ & cilíndrico-cônica & 500 & 4 \\
\hline 477 & $22^{\circ} 41^{\prime} 547^{\prime \prime}$ & $040^{\circ} 14^{\prime} 04,5^{\prime \prime}$ & $16 / 05 / 2002$ & oblíquo & $1.000 \mathrm{~m}$ & cilíndrico-cônica & 500 & 2 \\
\hline 483 & $22^{\circ} 33^{\prime} 37,0^{\prime \prime}$ & $040^{\circ} 19^{\prime} 10,0^{\prime \prime}$ & $17 / 05 / 2002$ & oblíquo & $50 \mathrm{~m}$ & bongô & 500 & 2 \\
\hline 6951 & $22^{\circ} 35^{\prime} 08,5^{\prime \prime}$ & $039^{\circ} 46^{\prime} 22,3^{\prime \prime}$ & $06 / 12 / 2002$ & vertical & $0-50 \mathrm{~m}$ & cilíndrico-cônica & 200 & 1 \\
\hline
\end{tabular}

Referências: Menezes \& Figueiredo, 1980; Watson et al., 1996; Smith-Vaniz, 2002; Ditty et al., 2004; Laroche et al., 2006; Fahay, 2007. 


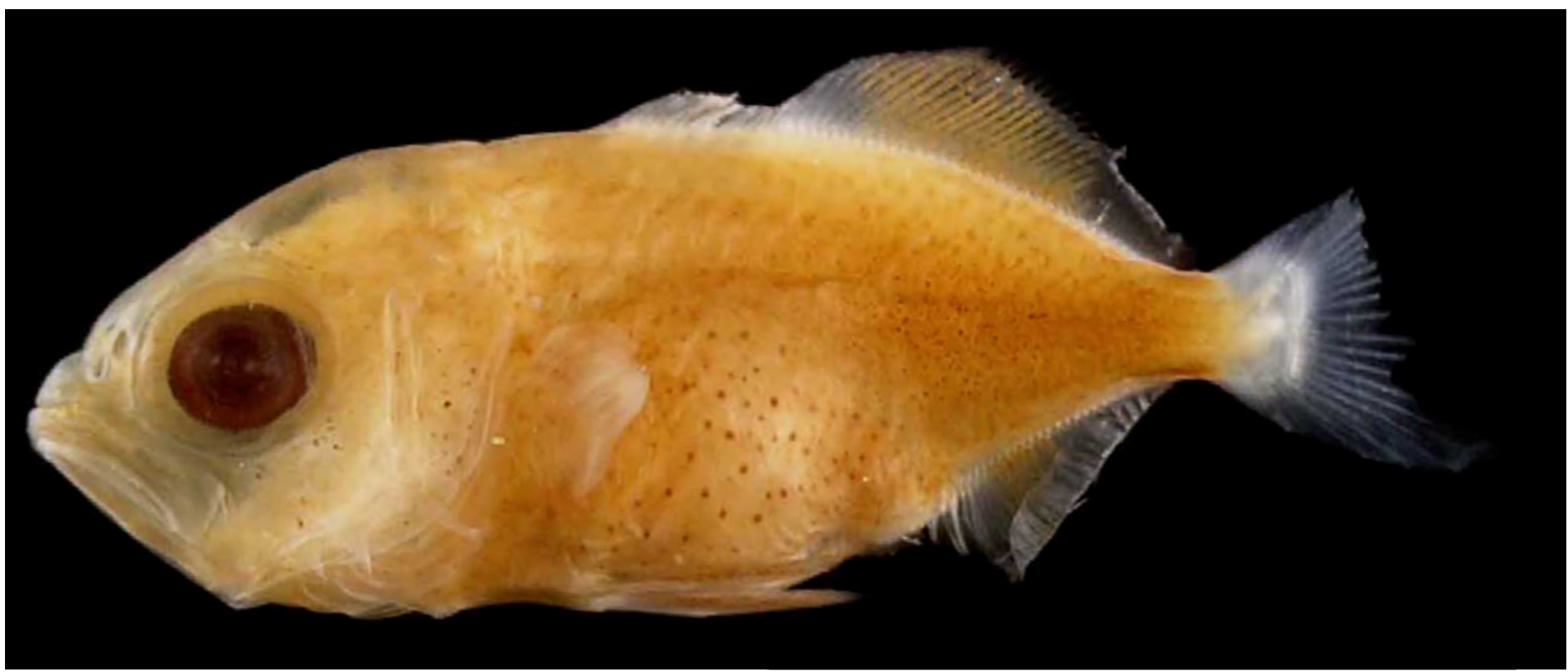

Figura 114 - Seriola dumerili. DZUFRJ 21384; Pós-flexão; CP 8,6 mm.

\section{Seriola dumerili (Risso, 1810)}

As larvas dessa espécie não apresentam crista supraoccipital, durante todos os estágios de desenvolvimento. Possui espinhos simples e proeminentes no pré-opérculo e na região pós-temporal. Apresenta pigmentos no dorso da cabeça, na mandíbula, região dorsal da vesícula gasosa, massa visceral e intestino. Pigmentos presentes também na linha lateral, regiões dorsal e ventral do corpo, extremidade da notocorda e membranas das nadadeiras. Em pós-flexão a pigmentação aumenta na cabeça e no corpo, concentrando-se nas margens dorsal, ventral e na linha lateral. As nadadeiras dorsal, anal, pélvica e caudal são pigmentadas. O pedúnculo caudal não tem pigmentação até a transformação. Número total de miômeros: 24.

Tamanho: pós-flexão 8,6 mm.

Habitat: espécie marinha, pelágica, ocorre em mar aberto em águas tropicais e subtropicais até $450 \mathrm{~m}$ de profundidade.

Nome vulgar: Olho de boi.

Georreferenciamento

\begin{tabular}{|c|c|c|c|c|c|c|c|c|}
\hline DZUFRJ & Latitude (S) & Longitude (W) & Data & $\begin{array}{c}\text { Tipo de } \\
\text { arrasto }\end{array}$ & $\begin{array}{c}\text { Profundidade } \\
\text { de coleta }\end{array}$ & Rede & $\begin{array}{c}\text { Malha } \\
(\boldsymbol{\mu m})\end{array}$ & $\begin{array}{c}\mathbf{N}^{\circ} \text {. de } \\
\text { inds. }\end{array}$ \\
\hline 21384 & $22^{\circ} 285^{\prime} 8^{\prime}$ & $039^{\circ} 55,72^{\prime}$ & $16 / 06 / 2003$ & horizontal & superfície & nêuston & 500 & 1 \\
\hline
\end{tabular}

Referências: Menezes \& Figueiredo, 1980; Watson et al., 1996; Smith-Vaniz, 2002; Ditty et al., 2004; Laroche et al., 2006; Fahay, 2007. 


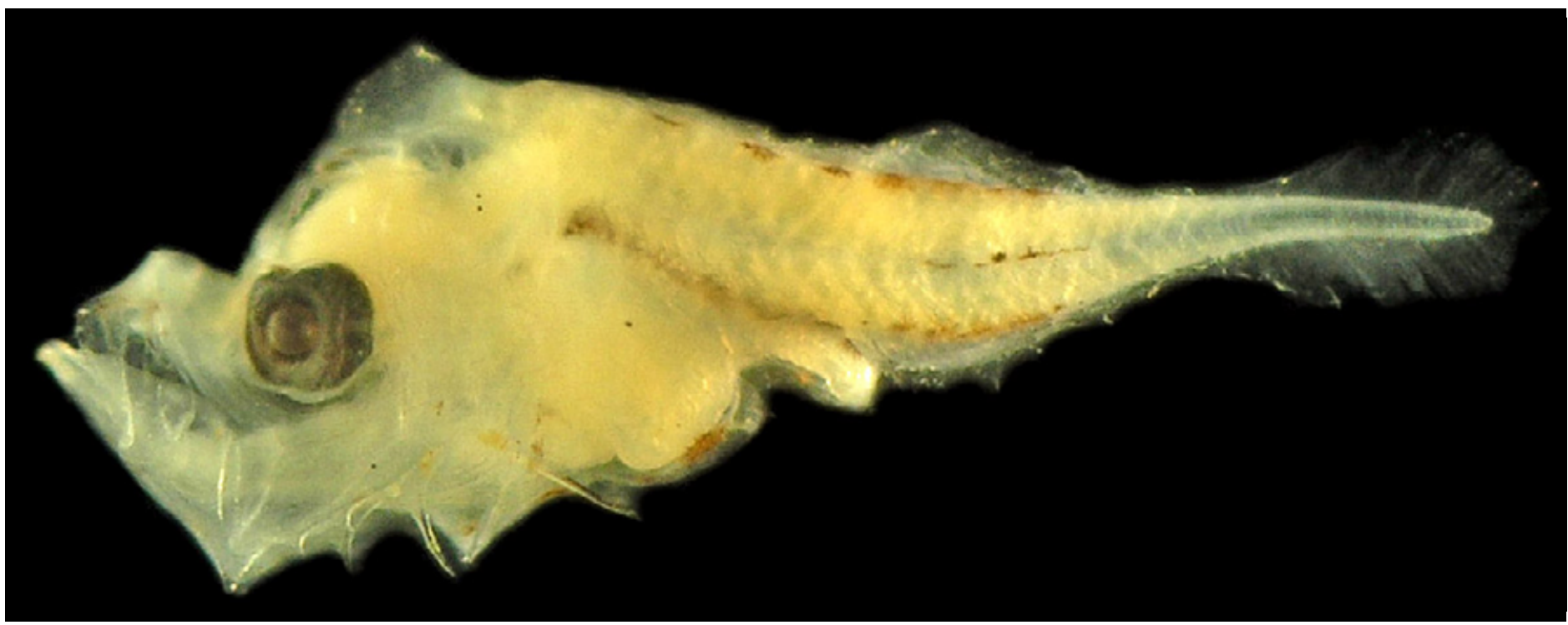

Figura 115 - Trachurus lathami. DZUFRJ 27391; Pré-flexão; CP 2,9 mm.

\section{Trachurus lathami Nichols, 1920}

A crista supraoccipital está presente até o estágio de transformação. As larvas em pré-flexão, apresentam pigmentos na mandíbula (ângulo inferior e extremidade), abaixo da massa visceral, base da nadadeira peitoral, dorso da cabeça, nuca, superfície dorsal da vesícula gasosa e massa visceral. Os pigmentos dorsais aparecem espaçados e há uma fileira de pigmentos na linha mediana do corpo. Em flexão, forma-se uma série pontual de pigmentos, ventralmente, na massa visceral, região posterior do intestino e ao longo da margem ventral do corpo e da cauda. Em pós-flexão a pigmentação prolifera-se sobre o dorso da cabeça, acima e abaixo da massa visceral, na porção final do intestino e na linha lateral do corpo. O número de raios das nadadeiras dorsal (VIII+I, 30-32) e anal (II+I, 27-28) também separa essa espécie dos demais carangídeos. Número total de miômeros: 24.

Tamanho: pré-flexão 2,7 mm.

Habitat: espécie marinha, pelágica ocorre em águas subtropicais entre 50 e $90 \mathrm{~m}$ de profundidade. Vive próximo ao fundo e às vezes na superfície; não é comum próximo à costa.

Nome vulgar: Chicharro lombo preto.

\section{Georreferenciamento}

\begin{tabular}{|c|c|c|c|c|c|c|c|c|}
\hline DZUFRJ & Latitude (S) & Longitude (W) & Data & $\begin{array}{c}\text { Tipo de } \\
\text { arrasto }\end{array}$ & $\begin{array}{c}\text { Profundidade } \\
\text { de coleta }\end{array}$ & Rede & $\begin{array}{c}\text { Malha } \\
(\boldsymbol{\mu m})\end{array}$ & $\begin{array}{c}\mathbf{N}^{\circ} \text {. de } \\
\text { inds. }\end{array}$ \\
\hline 970 & $22^{\circ} 43^{\prime} 50,4^{\prime \prime}$ & $040^{\circ} 02^{\prime} 425^{\prime \prime}$ & $07 / 12 / 2002$ & vertical & $0-50 \mathrm{~m}$ & cilíndrico-cônica & 200 & 1 \\
\hline
\end{tabular}

Referências: Menezes \& Figueiredo, 1980; Katsuragawa \& Matsuura, 1992; Watson et al., 1996; Smith-Vaniz, 2002; Ditty et al., 2004; Laroche et al., 2006; Fahay, 2007. 


\section{Família Coryphaenidae}

A família Coryphaenidae é marinha e ocorre nos oceanos Atlântico, Índico e Pacífico. Compreende um gênero e duas espécies. São peixes epipelágicos, encontrados em áreas costeiras e oceânicas, que vivem associados a objetos à deriva no mar. Tem grande importância comercial no litoral brasileiro. Os representantes dessa família possuem o corpo alongado e comprimido, com nadadeiras dorsal e anal muito longas e ausência de espinhos nas mesmas. O padrão de pigmentação do corpo durante todo desenvolvimento larval é importante para a identificação das duas espécies.

No Brasil já foram identificadas duas espécies nas fases de larva e adulto: Coryphaena equiselis Linnaeus, 1758 e Coryphaena hippurus Linnaeus, 1758. Nesse estudo é contemplada a espécie Coryphaena hippurus. 


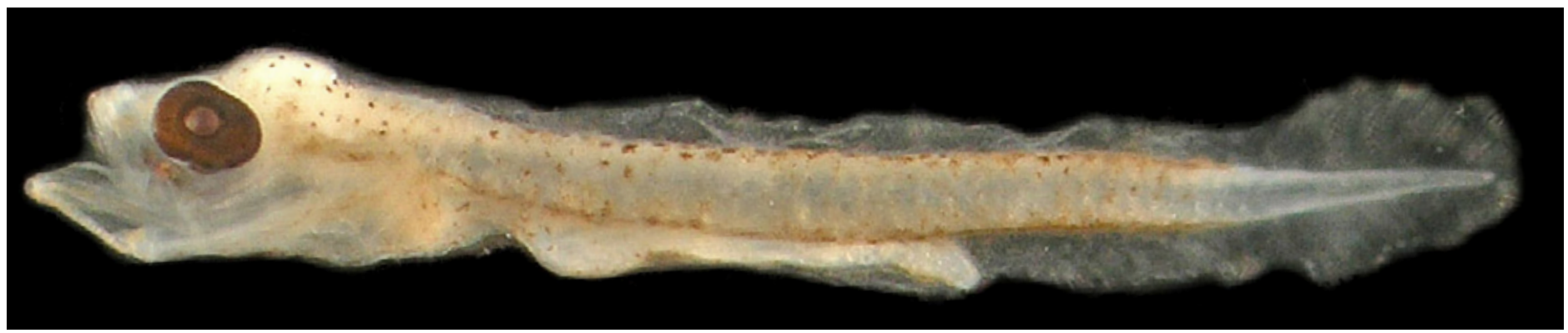

Figura 116 - A: Coryphaena hippurus. DZUFRJ 31422; Pré-flexão; CP 4,7 mm.

\section{Coryphaena hippurus Linnaeus, 1758}

Possui o corpo alongado, cabeça bem desenvolvida, intestino longo e uma única nadadeira dorsal longa e sem espinhos. Tem grandes espinhos na margem posterior do pré-opérculo e espinhos menores lateralmente. Essa espécie pode ser separada de Coryphaena equiselis principalmente, pelo padrão de pigmentação do corpo. No estágio de pré-flexão possuem o corpo todo pigmentado com exceção do pedúnculo caudal. Nos estágios de flexão e pós-flexão, começam a formar barras verticais de pigmento que se estendem até as nadadeiras dorsal e anal.

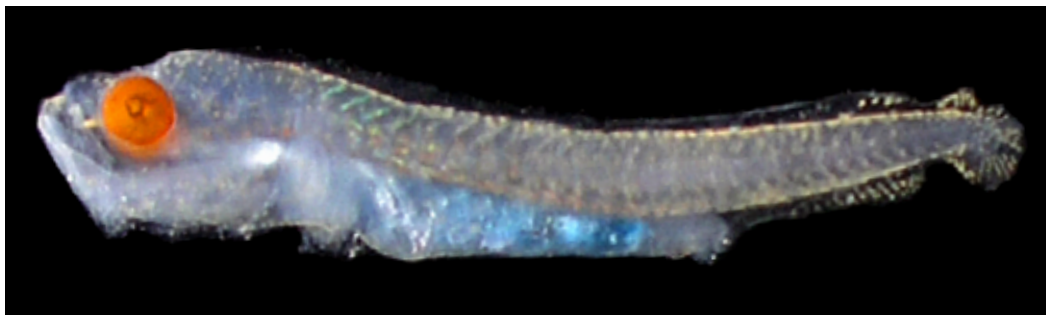

Figura 116 - B: DZUFRJ 1327; Flexão; CP 7,2 mm.

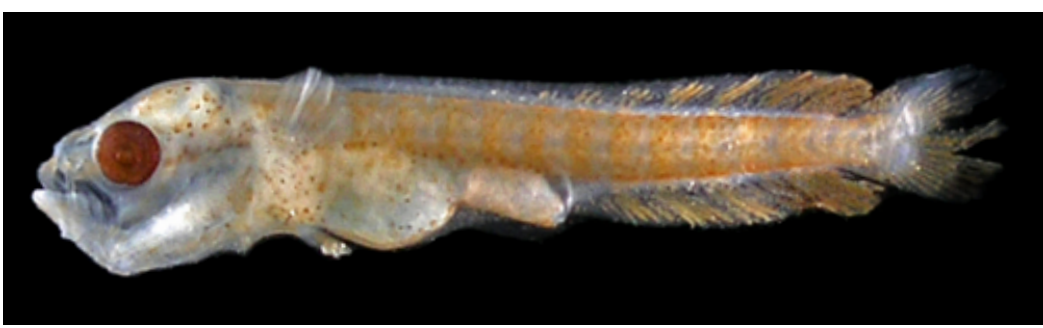

Figura 116 - C: DZUFRJ 2701; Pós-flexão; CP 10,5 mm. Há melanóforos na membrana entre os raios de todas as nadadeiras. O número total de miômeros varia entre 30 e 31.

Tamanho: pré-flexão 4,0-5,0 mm; flexão 6,6-7,5 mm; pós-flexão 10,5 mm.

Habitat: espécie marinha, epipelágica, ocorre em águas tropicais e subtropicais em áreas costeiras e oceânicas.

Nome vulgar: Dourado.

\section{Georreferenciamento}

\begin{tabular}{|c|c|c|c|c|c|c|c|c|}
\hline DZUFRJ & Latitude (S) & Longitude (W) & Data & $\begin{array}{c}\text { Tipo de } \\
\text { arrasto }\end{array}$ & $\begin{array}{c}\text { Profundidade } \\
\text { de coleta }\end{array}$ & Rede & $\begin{array}{c}\text { Malha } \\
\text { ( } \boldsymbol{\mu m} \text { ) }\end{array}$ & $\begin{array}{c}\mathbf{N}^{\circ} \text {. de } \\
\text { inds. }\end{array}$ \\
\hline 645 & $22^{\circ} 38^{\prime} 25,0^{\prime \prime}$ & $040^{\circ} 17^{\prime} 41,0^{\prime \prime}$ & $19 / 05 / 2002$ & oblíquo & $40 \mathrm{~m}$ & bongô & 330 & 1 \\
\hline 663 & $22^{\circ} 33^{\prime} 47,7^{\prime \prime}$ & $040^{\circ} 12^{\prime} 20,5^{\prime \prime}$ & $17 / 05 / 2002$ & oblíquo & $50 \mathrm{~m}$ & bongô & 500 & 1 \\
\hline 1285 & $22^{\circ} 06^{\prime} 52,3^{\prime \prime}$ & $039^{\circ} 48^{\prime} 46,2^{\prime \prime}$ & $11 / 05 / 2002$ & oblíquo & até a termoclina & bongô & 500 & 1 \\
\hline 1327 & $22^{\circ} 03^{\prime} 03,3^{\prime \prime}$ & $039^{\circ} 50^{\prime} 39,0^{\prime \prime}$ & $10 / 05 / 2002$ & oblíquo & até a termoclina & bongô & 330 & 1 \\
\hline 1337 & $22^{\circ} 06^{\prime} 37,8^{\prime \prime}$ & $039^{\circ} 49^{\prime} 44,8^{\prime \prime}$ & $10 / 05 / 2002$ & oblíquo & até a termoclina & bongô & 330 & 1 \\
\hline 1341 & $22^{\circ} 06^{\prime} 52,3^{\prime \prime}$ & $039^{\circ} 48^{\prime} 46,2^{\prime \prime}$ & $11 / 05 / 2002$ & oblíquo & até a termoclina & bongô & 330 & 1 \\
\hline 1381 & $22^{\circ} 08^{\prime} 14,9^{\prime \prime}$ & $039^{\circ} 46^{\prime} 34,6^{\prime \prime}$ & $11 / 05 / 2002$ & oblíquo & até a termoclina & bongô & 330 & 1 \\
\hline 22508 & $22^{\circ} 31^{\prime} 58,9^{\prime \prime}$ & $040^{\circ} 02^{\prime} 53,4^{\prime \prime}$ & $07 / 11 / 2001$ & oblíquo & $1.000 \mathrm{~m}$ & cilíndrico-cônica & 500 & 2 \\
\hline 23210 & $22^{\circ} 28,58^{\prime}$ & $039^{\circ} 55,72^{\prime}$ & $16 / 06 / 2003$ & horizontal & superfície & nêuston & 500 & 1 \\
\hline
\end{tabular}

Referências: Ambrose, 1996c; Ditty, 2006d; Fahay, 2007. 


\section{Família Bramidae}

A família Bramidae é marinha e ocorre nos oceanos Atlântico, Índico e Pacífico. Vive em regiões oceânicas e tem distribuição circumglobal. Compreende sete gêneros com aproximadamente 22 espécies. Os adultos são pelágicos e os estágios mais jovens podem ser capturados em regiões mais afastadas da costa. As larvas são caracterizadas pelo grande número de miômeros e nadadeiras bem desenvolvidas. A região ao redor da cabeça e do intestino possui muitos pigmentos. A cauda é longa com poucos pigmentos, que se distribuem pelas margens dorsal e ventral do corpo até a notocorda.

No Brasil já foram identificadas seis espécies nas fases de larva e adulto. Nesse estudo é contemplada a espécie Brama dussumieri. 


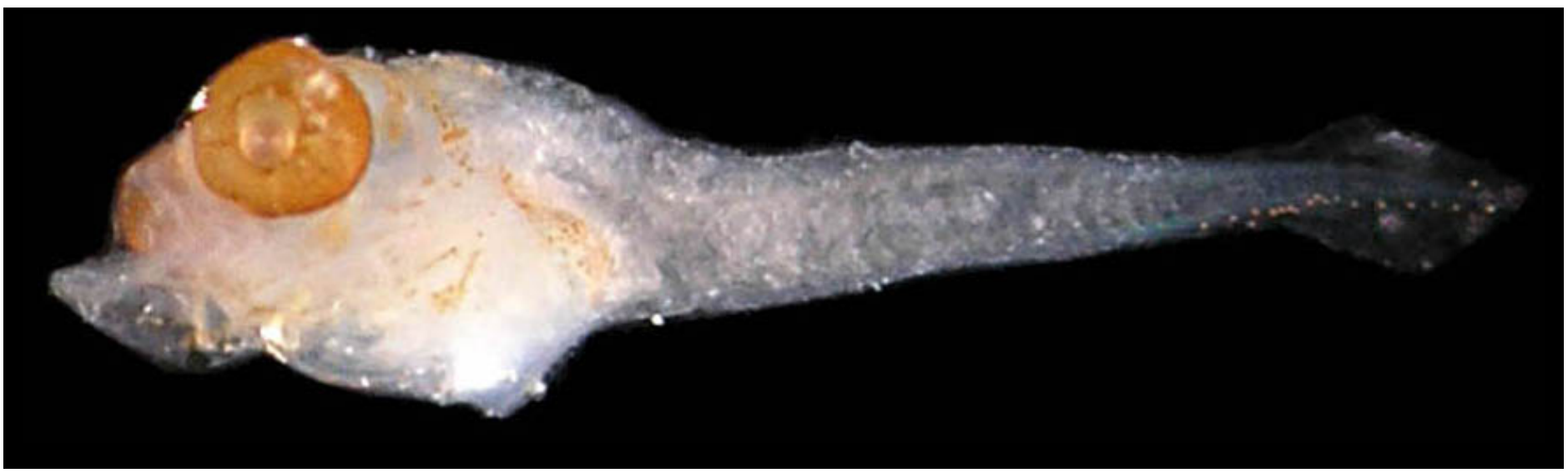

Figura 117: Brama dussumieri. DZUFRJ 20076; Pré-flexão; CP 4,4 mm.

\section{Brama dussumieri Cuvier, 1831}

As larvas dessa espécie possuem entre 40-43 miômeros e apresentam corpo mais alto anteriormente, com cabeça e focinho arredondados. Desde o estágio de pré-flexão, possuem melanóforos que cobrem toda a cabeça e a região do trato digestório, além de alguns melanóforos próximos ao fim da notocorda. Com o decorrer do desenvolvimento larval, na região anterior da nadadeira dorsal existem melanóforos que se desenvolvem e se espalham até a cauda. Além do padrão de pigmentação, o número de raios das nadadeiras (dorsal 33-35; anal 27-29 e peitoral 19-21) são importantes na identificação das larvas dessa espécie.

Tamanho: pré-flexão 3,2-4,5 mm.

Habitat: espécie marinha, epi-mesopelágica, ocorre em águas tropicais até $300 \mathrm{~m}$ de profundidade.

Nome vulgar: Palombeta.

\section{Georreferenciamento}

\begin{tabular}{|c|c|c|c|c|c|c|c|c|}
\hline DZUFRJ & Latitude (S) & Longitude (W) & Data & $\begin{array}{c}\text { Tipo de } \\
\text { arrasto }\end{array}$ & $\begin{array}{c}\text { Profundidade } \\
\text { de coleta }\end{array}$ & Rede & $\begin{array}{c}\text { Malha } \\
\text { ( } \boldsymbol{\mu m})\end{array}$ & $\begin{array}{c}\text { No. de } \\
\text { inds. }\end{array}$ \\
\hline 1228 & $22^{\circ} 02^{\prime} 30,0^{\prime \prime}$ & $039^{\circ} 49^{\prime} 41,2^{\prime \prime}$ & $12 / 05 / 2002$ & oblíquo & $1.000 \mathrm{~m}$ & cilíndrico-cônica & 500 & 1 \\
\hline 1287 & $22^{\circ} 06^{\prime} 52,3^{\prime \prime}$ & $039^{\circ} 48^{\prime} 46,2^{\prime \prime}$ & $11 / 05 / 2002$ & oblíquo & até a termoclina & bongô & 500 & 1 \\
\hline 7507 & $21^{\circ} 58^{\prime} 31,0^{\prime \prime}$ & $039^{\circ} 50^{\prime} 29,7^{\prime \prime}$ & $11 / 10 / 2001$ & oblíquo & $1.000 \mathrm{~m}$ & cilíndrico-cônica & 500 & 1 \\
\hline 20076 & $22^{\circ} 32^{\prime} 50,0^{\prime \prime}$ & $040^{\circ} 04^{\prime} 09^{\prime \prime}$ & $06 / 11 / 2001$ & oblíquo & $1.000 \mathrm{~m}$ & cilíndrico-cônica & 500 & 1 \\
\hline
\end{tabular}

Referências: Menezes \& Figueiredo, 1980; Moser \& Mundy, 1996; Richards., 2006h; Fahay, 2007. 


\section{Família Lutjanidae}

A família Lutjanidae é representada por peixes marinhos, que raramente são encontrados em estuários e na água doce, principalmente quando juvenis. Vivem em regiões tropicais e subtropicais dos oceanos Atlântico, Índico e Pacífico. É uma das famílias de maior importância econômica para o litoral brasileiro. Compreende 17 gêneros com aproximadamente 105 espécies.

Apresentam corpo alongado até a flexão da notocorda, quando começa a ficar mais alto à medida que a larva cresce. São caracterizados por uma grande boca terminal e a margem do pré-opérculo constituída por muitos espinhos. A nadadeira dorsal é contínua formada por IX-XII espinhos, sendo o primeiro curto e os demais extremamente a moderadamente longos, e 9-18 raios. Nadadeira anal: III, 7-9. Presença de grande espinho pélvico, frequentemente serrilhado. 0 padrão de pigmentação varia muito de acordo com a espécie.

No Brasil já foram identificadas 16 espécies nas fases de larva e adulto. Nesse estudo é contemplada a espécie Lutjanus sp. 


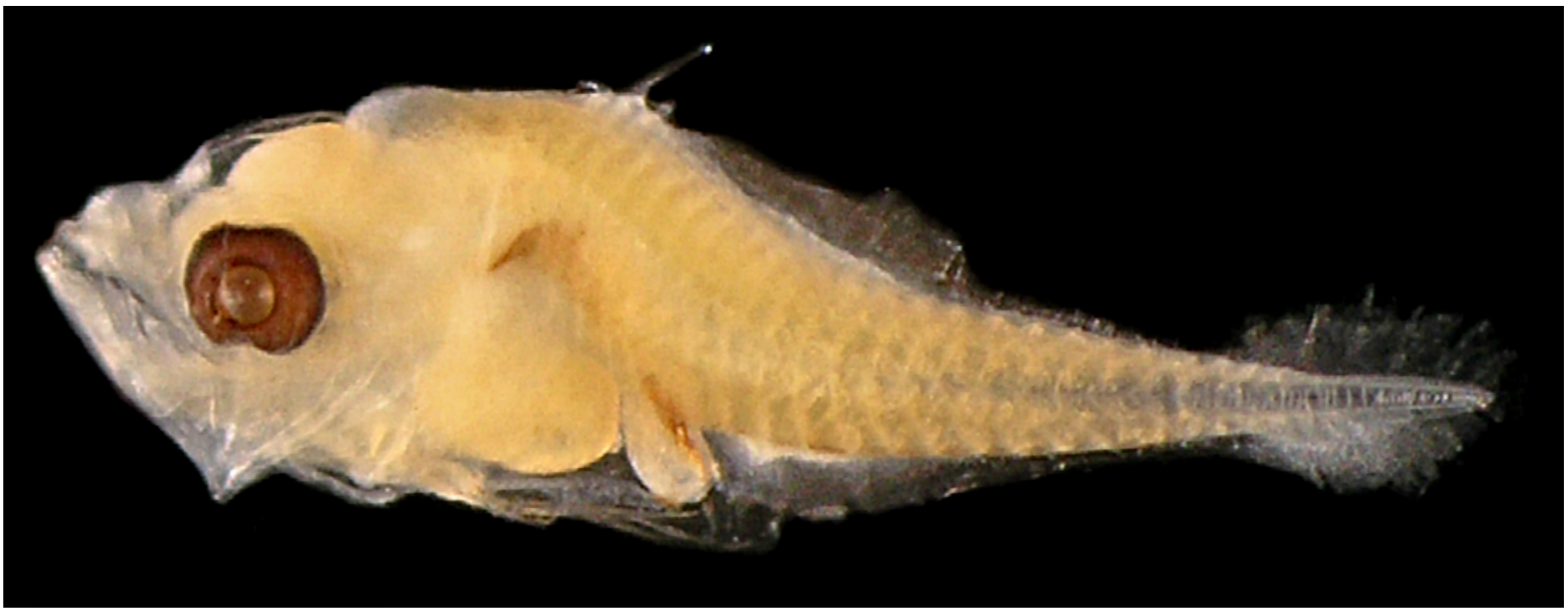

Figura 118: Lutjanus sp. DZUFRJ 15647; Pré-flexão; CP 3,0 mm.

\section{Lutjanus sp.}

Apresentam o corpo alongado no início do desenvolvimento, tornando-se mais alto, de acordo com o crescimento. Possuem uma grande boca terminal e vários espinhos não serrilhados na região do pré-opérculo. O padrão de pigmentação é importante para separar as espécies de Lutjanus. Nesse estudo a pigmentação das larvas não estava muito preservada impossibilitando a identificação até espécie. Número de miômeros: 24.

Tamanho: pré-flexão 3,0-4,0 mm.

Habitat: as espécies de Lutjanus são marinhas e demersais. No Brasil já foram registradas nove espécies de Lutjanus.

\section{Georreferenciamento}

\begin{tabular}{|c|c|c|c|c|c|c|c|c|}
\hline DZUFRJ & Lati & Longitude (W) & Data & $\begin{array}{l}\text { Tipo de } \\
\text { arrasto }\end{array}$ & $\begin{array}{c}\text { Profundidade } \\
\text { de coleta }\end{array}$ & Rede & $\begin{array}{l}\text { Malha } \\
(\mu \mathrm{m})\end{array}$ & $\begin{array}{l}\text { No. de } \\
\text { inds. }\end{array}$ \\
\hline 46 & & & $17 / 0$ & oblíquo & $50 \mathrm{~m}$ & & 500 & 1 \\
\hline 522 & 22031'27,0" & 040o16'56,0" & $17 / 05 / 2002$ & oblíquo & $600 \mathrm{~m}$ & cilíndrico-cônica & 500 & 2 \\
\hline
\end{tabular}

Referências: Menezes \& Figueiredo, 1980; Lindeman et al., 2006; Fahay, 2007; Froese \& Pauly, 2014. 


\section{Família Gerreidae}

A família Gerreidae é marinha e ocasionalmente ocorre em águas salobras. Os representantes dessa família vivem em águas costeiras e estuarinas, principalmente, próximas ao fundo. Compreende oito gêneros com aproximadamente 44 espécies.

As larvas dessa família possuem olhos grandes e focinho pontudo, com a boca pequena e geralmente protrátil. Apresentam de dois a três espinhos e de 7-10 raios na nadadeira anal. Os espinhos da cabeça são pequenos e restritos a região do pré-opérculo. Possuem pigmentação limitada à superfície dorsal da cabeça, na vesícula gasosa e intestino. O número de melanóforos aumenta nas margens dorsal e ventral do corpo, no decorrer do desenvolvimento larval.

No Brasil já foram identificadas 11 espécies nas fases de larva e adulto. Nesse estudo é contemplada a espécie Eucinostomus sp. 


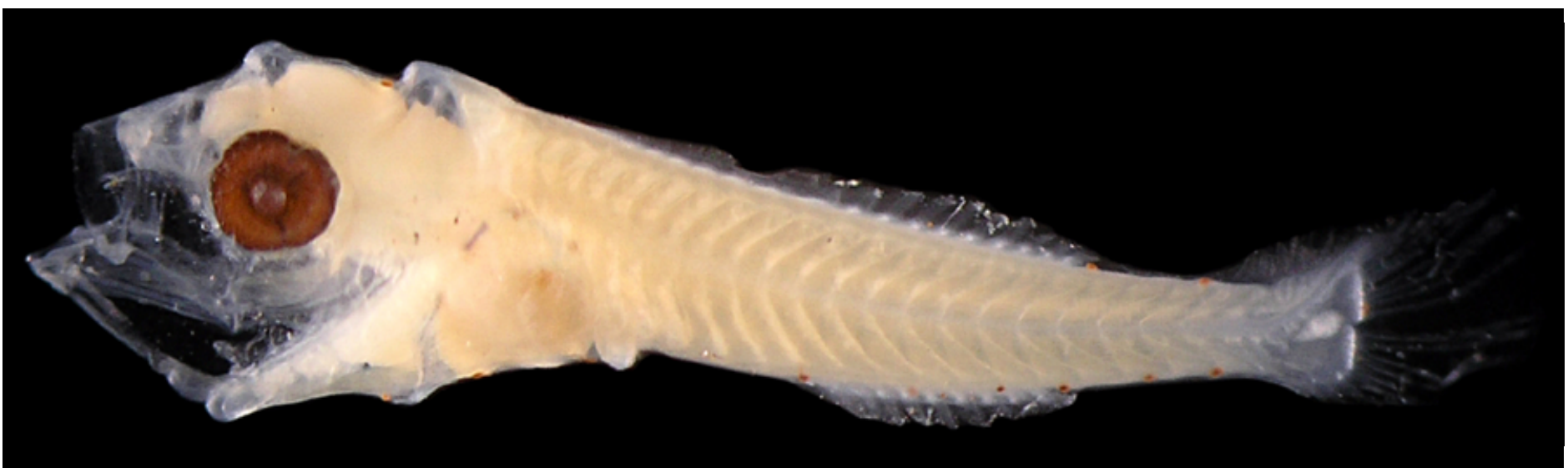

Figura 119- A: Eucinostomus sp. DZUFRJ 509; Flexão; CP 4,5 mm.

\section{Eucinostomus sp.}

As larvas de Eucinostomus apresentam pigmentação característica na cabeça. Melanóforos estrelados pareados começam a se formar na base do encéfalo e, à medida que a larva cresce,

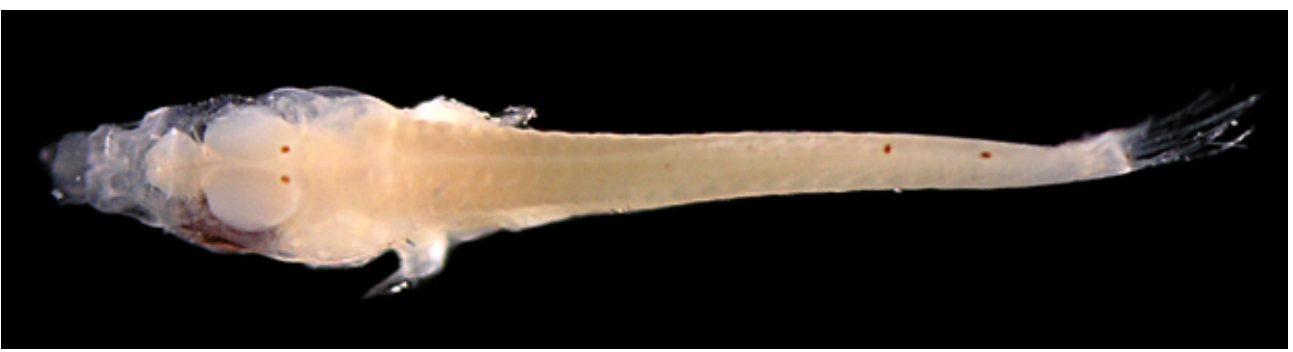

Figura 119 - B: Melanóforos pareados na base do encéfalo e dois pigmentos pós-dorsais. outros melanóforos aparecem, originando o formato da letra " $U$ ". Presença de pequenos melanóforos atrás dos olhos e um antes do intestino e de pigmentos internos na base da nadadeira peitoral. Apresentam um a três pigmentos na base da nadadeira dorsal (após a formação da mesma) e mais dois pós-dorsais. Na margem ventral, presença de três a oito pigmentos na base da nadadeira anal e três a seis pós-anais. A região do pré-opérculo possui poucos espinhos. Número total de miômeros: 24. No Brasil já foram registradas oito espécies de Eucinostomus.

Tamanho: flexão 4,3-4,5 mm.

Habitat: as espécies de Eucinostomus são demersais e ocorrem em águas tropicais costeiras. São marinhas, mas algumas vivem em águas salobras ou água doce.

\section{Georreferenciamento}

\begin{tabular}{|c|c|c|c|c|c|c|c|c|}
\hline DZUFRJ & Latitude (S) & Longitude (W) & Data & $\begin{array}{c}\text { Tipo de } \\
\text { arrasto }\end{array}$ & $\begin{array}{c}\text { Profundidade } \\
\text { de coleta }\end{array}$ & Rede & $\begin{array}{c}\text { Malha } \\
(\boldsymbol{\mu m})\end{array}$ & $\begin{array}{c}\mathbf{N}^{\circ} \text {. de } \\
\text { inds. }\end{array}$ \\
\hline 509 & $22^{\circ} 31^{\prime} 27,0^{\prime \prime}$ & $040^{\circ} 16^{\prime} 56,0^{\prime \prime}$ & $17 / 05 / 2002$ & oblíquo & $600 \mathrm{~m}$ & cilíndrico-cônica & 500 & 2 \\
\hline
\end{tabular}

Referências: Menezes \& Figueiredo, 1980; Watson, 1996d; Araújo \& Santos, 1999; Gilmore Jr \& Greenfield, 2002; Jimenez-Rosenberg et al., 2006; Powell \& Greene, 2006a; Fahay, 2007 


\section{Família Mullidae}

Os peixes pertencentes à família Mullidae são pequenos e possuem corpo alongado (24 miômeros). Geralmente, são encontrados em águas costeiras na plataforma, próximo ao fundo.

Os membros dessa família possuem as nadadeiras dorsais bem separadas. A nadadeira pélvica está inserida logo anteriormente ou abaixo da primeira nadadeira dorsal. A origem da nadadeira anal está localizada atrás da origem da segunda nadadeira dorsal. Difere de outras famílias pelas seguintes características: na pré-flexão o intestino é curto e compacto, geralmente, $35 \%$ do CP, alcançando 50-60\% CP após a flexão da notocorda; espaço entre o ânus e a nadadeira anal grande que vai diminuindo com o crescimento do intestino; poucos ou nenhum espinho no pré-opérculo; nadadeiras dorsais separadas; poucos raios nas nadadeiras dorsal e anal.

No Brasil já foram identificadas quatro espécies nas fases de larva e adulto: Mulloidichthys martinicus (Cuvier, 1829); Mullus argentinae Hubbs \& Marini, 1933; Pseudupeneus maculatus (Bloch, 1793) e Upeneus parvus Poey, 1852. Nesse estudo é contemplada a espécie Upeneus parvus. 


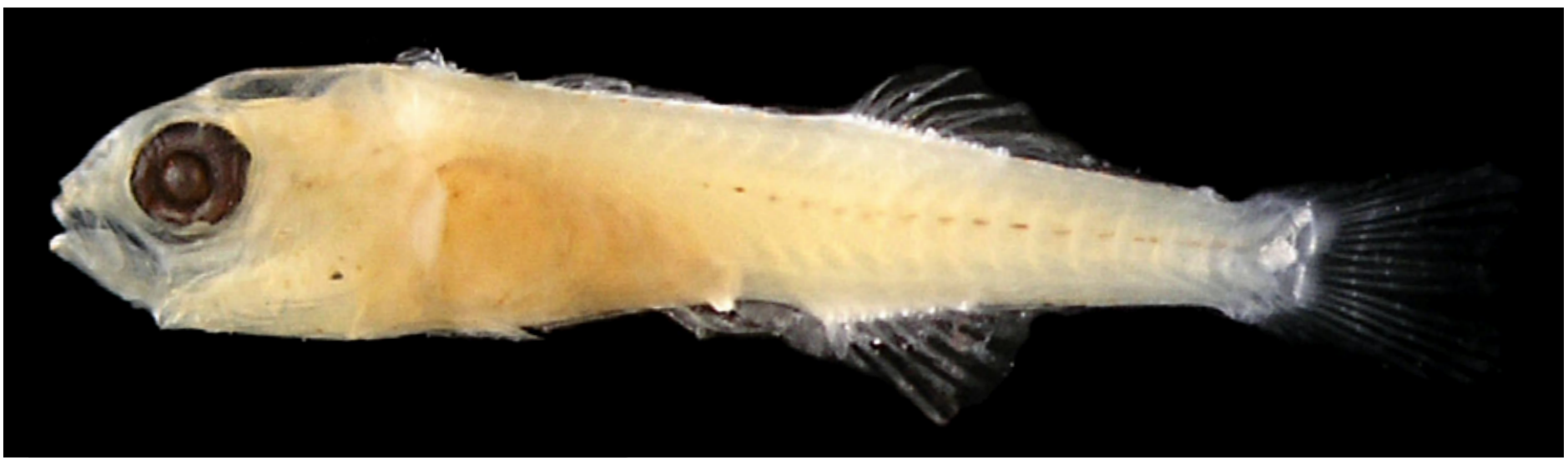

Figura 120 - A: Upeneus parvus. DZUFRJ 2700; Flexão; CP 7,0 mm.

\section{Upeneus parvus Poey, 1852}

Possui o corpo alongado (24 miômeros), comprimido lateralmente, cabeça de tamanho moderado, arredondada dorsalmente. Não tem espinhos cefálicos. As nadadeiras dorsais são bem separadas, com VII espinhos igualmente espaçados na primeira dorsal, sendo o primeiro e o segundo de comprimentos semelhantes. As bases da segunda dorsal e da nadadeira anal são curtas, com oito raios cada. As larvas em flexão já apresentam grandes melanóforos estrelados na porção posterior do encéfalo, formando um triângulo, que segue pela margem dorsal do corpo como uma dupla fileira

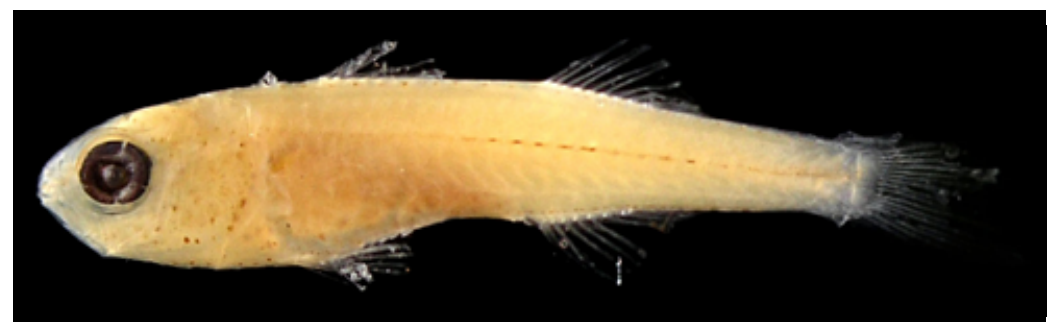

Figura 120 - B: DZUFRJ 2700; Pós-flexão; CP 10,5 mm.

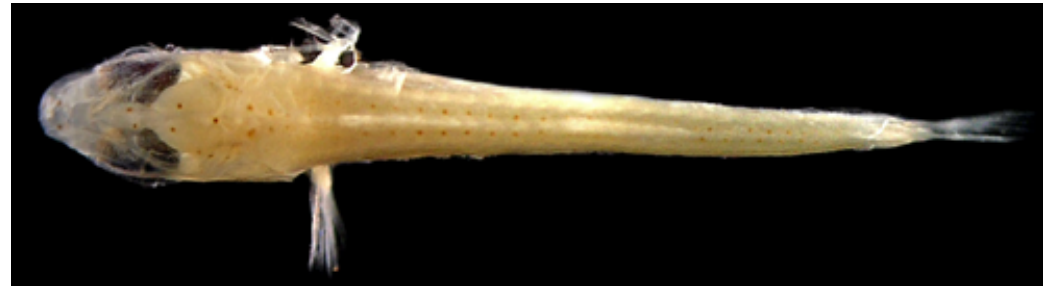

Figura 120 - C: Detalhe da pigmentação da região dorsal durante a pós-flexão.

de pigmentos, até o pedúnculo caudal. A cabeça possui pigmentação característica, com um par de melanóforos na extremidade da maxila superior e entre os olhos, na região anterior do encéfalo. A linha lateral também é muito pigmentada, acompanhada de pequenos melanóforos internos.

Tamanho: flexão 5,0-8,5 mm; pós-flexão 10,2-10,5 mm.

Habitat: espécie marinha, demersal, ocorre em águas tropicais até $100 \mathrm{~m}$ de profundidade.

Nome vulgar: Trilha anã.

\section{Georreferenciamento}

\begin{tabular}{|c|c|c|c|c|c|c|c|c|}
\hline DZUFRJ & Latitude (S) & Longitude (W) & Data & $\begin{array}{l}\text { Tipo de } \\
\text { arrasto }\end{array}$ & $\begin{array}{c}\text { Profundidade } \\
\text { de coleta }\end{array}$ & Rede & $\begin{array}{c}\text { Malha } \\
(\mu \mathrm{m})\end{array}$ & $\begin{array}{l}\text { No. de } \\
\text { inds. }\end{array}$ \\
\hline 466 & $22^{\circ} 33^{\prime} 37,0^{\prime \prime}$ & $040^{\circ} 19^{\prime} 10,0^{\prime \prime}$ & $17 / 05 / 2002$ & oblíquo & $50 \mathrm{~m}$ & bongô & 500 & 2 \\
\hline 2692 & $21^{\circ} 57,51^{\prime}$ & $039^{\circ} 49,57^{\prime}$ & $19 / 06 / 2003$ & horizontal & superfície & nêuston & 500 & 1 \\
\hline 2700 & $22^{\circ} 28,58^{\prime}$ & $039^{\circ} 55,72^{\prime}$ & $16 / 06 / 2003$ & horizontal & superfície & nêuston & 500 & 3 \\
\hline 2709 & $22^{\circ} 39,68^{\prime}$ & $040^{\circ} 03,24^{\prime}$ & $14 / 06 / 2003$ & horizontal & superfície & nêuston & 500 & 1 \\
\hline 22383 & $22^{\circ} 07^{\prime} 58,8^{\prime \prime}$ & $039^{\circ} 49^{\prime} 08,9^{\prime \prime}$ & $01 / 12 / 2002$ & vertical & $0-50 m$ & cilíndrico-cônica & 500 & 1 \\
\hline
\end{tabular}

Referências: Menezes \& Figueiredo, 1985; Randall, 2002a; Watson, 1996e; Ditty et al., 2006b; Fahay, 2007. 


\section{Família Chaetodontidae}

A família Chaetodontidae é marinha e ocorre nos oceanos Atlântico, Índico e Pacífico. É tipicamente encontrada em regiões tropicais e subtropicais, porém poucas larvas são coletadas em amostragem de ictioplâncton. Compreende 11 gêneros com aproximadamente 122 espécies. Os representantes dessa família são caracterizados pelo corpo lateralmente comprimido e com formato ovalado. No entanto, durante o período larval o corpo pode apresentar-se mais delgado com focinho arredondado e curto. Possui forte pigmentação nas regiões dorsal e ventral do corpo, cabeça e intestino.

No Brasil já foram identificadas seis espécies nas fases de larva e adulto. Nesse estudo é contemplada a espécie Chaetodon sedentarius. 


\section{Chaetodon} sedentarius

\section{Poey, 1860}

A identificação das larvas do gênero Chaetodon baseia-se, principalmente, na contagem dos elementos das nadadeiras, permitindo apenas a identificação no estágio de pós-flexão. Nadadeira dorsal: VIII, 20-24; nadadeira anal: III,17-20 e nadadeira peitoral: I, 13-14. A pigmentação concentra-se na região da cabeça e na porção dorsal do corpo. Alguns melanóforos também são encontrados espalhados na margem ventral do corpo e acompanhando a linha lateral. Presença de pigmentos na membrana entre os espinhos da

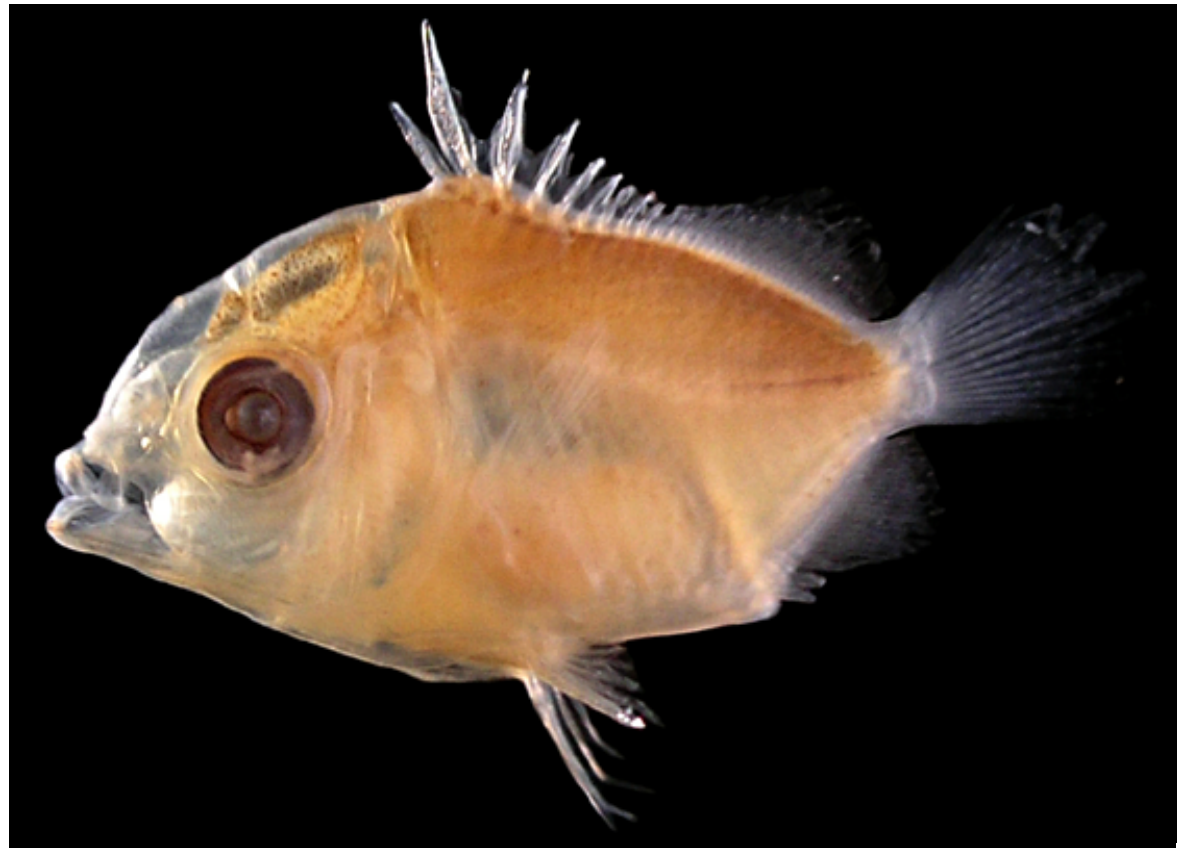

Figura 121: Chaetodon sedentarius. DZUFRJ 7510; Pós-flexão; CP 11,0 mm. primeira nadadeira dorsal. Número total de miômeros: 24.

Tamanho: pós-flexão 11,0 mm.

Habitat: espécie marinha, pelágica, associada a formações coralinas, rochas e substratos. Ocorre em águas subtropicais entre 5 e $92 \mathrm{~m}$ de profundidade.

Nome vulgar: Borboleta namorada.

\section{Georreferenciamento}

\begin{tabular}{|c|c|c|c|c|c|c|c|c|}
\hline DZUFRJ & Latitude (S) & $\begin{array}{c}\text { Longitude } \\
\mathbf{( W )}\end{array}$ & Data & $\begin{array}{c}\text { Tipo de } \\
\text { arrasto }\end{array}$ & $\begin{array}{c}\text { Profundidade } \\
\text { de coleta }\end{array}$ & Rede & $\begin{array}{c}\text { Malha } \\
(\boldsymbol{\mu m})\end{array}$ & $\begin{array}{c}\text { No. de } \\
\text { inds. }\end{array}$ \\
\hline 7510 & $21^{\circ} 54^{\prime} 365^{\prime \prime}$ & $039^{\circ} 45^{\prime} 20,0^{\prime \prime}$ & $10 / 10 / 2001$ & oblíquo & $1.000 \mathrm{~m}$ & cilíndrico-cônica & 500 & 1 \\
\hline
\end{tabular}

Referências: Menezes \& Figueiredo, 1985; Burgess, 2002a; Kelly, $2006 a$. 


\section{Família Pomacanthidae}

A família Pomacanthidae é marinha e ocorre nos oceanos Atlântico, Índico e Pacífico. Vive em águas rasas próximo a formações coralinas e pedras, em grupos ou isoladamente. Compreende oito gêneros com aproximadamente 82 espécies.

O corpo é ovalado e muito comprimido lateralmente. É caracterizada pela presença de um forte espinho no ângulo do pré-opérculo. A boca é pequena e protrátil e o focinho um pouco saliente. Dados merísticos podem ajudar na separação dos gêneros, usando a combinação de dois ou mais elementos. A nadadeira dorsal é contínua: IX-XV, 15-37. Nadadeira anal: III, 14-25.

No Brasil já foram identificadas cinco espécies nas fases de larva e adulto: Centropyge aurantonotus Burgess, 1974; Holacanthus ciliaris (Linnaeus, 1758) e Holacanthus tricolor (Bloch, 1795); Pomacanthus arcuatus (Linnaeus, 1758); Pomacanthus paru (Bloch, 1787). Nesse estudo é contemplada a espécie Centropyge aurantonotus. 


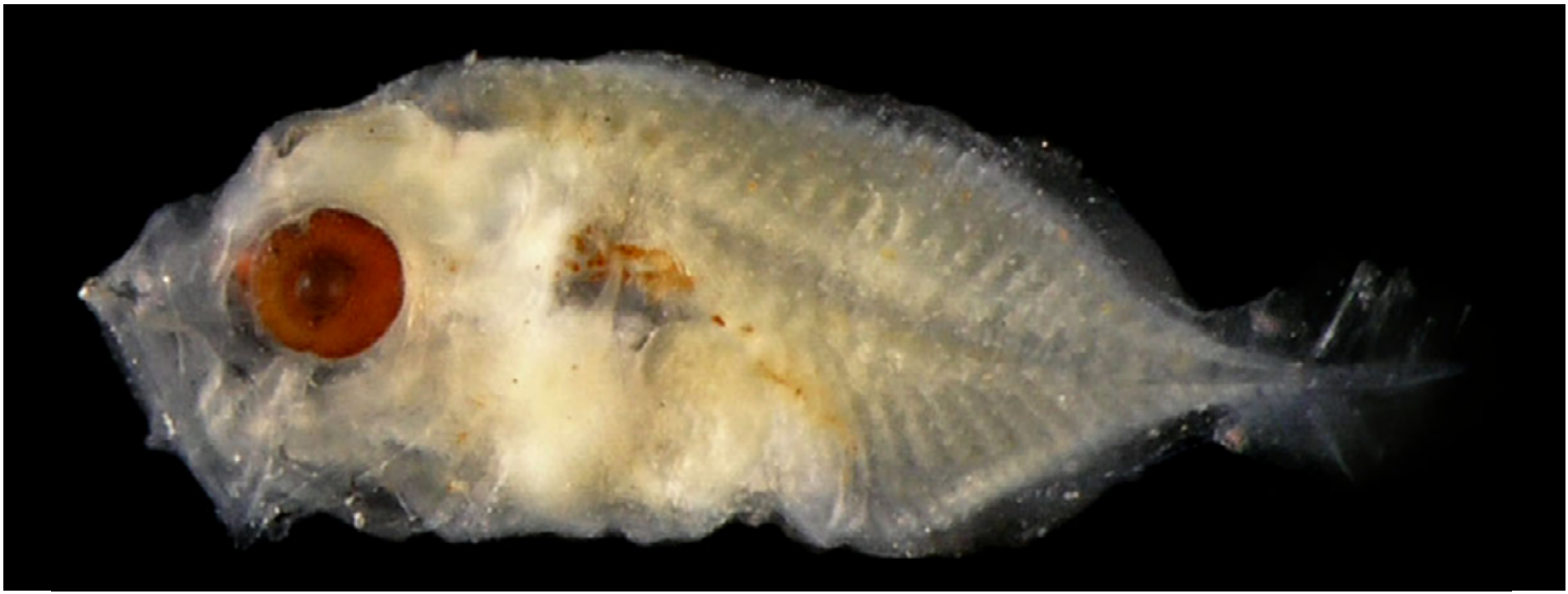

Figura 122 - A: Centropyge aurantonotus. DZUFRJ 352; Pré-flexão; CP 3,0 mm.

\section{Centropyge \\ aurantonotus Burgess, 1974}

A principal característica dessa espécie é o terceiro espinho dorsal mais alongado que os demais, a partir de larvas com 3,4 mm, ficando mais longo em larvas com $4,3 \mathrm{~mm}$ CP de comprimento. No estágio de pré-flexão possui corpo alto e pouco comprimido lateralmente, tornando-se discoide e muito comprimido lateralmente em pós-flexão. Durante a pré-flexão a concentração de pigmentos na cabeça e na região interna acima

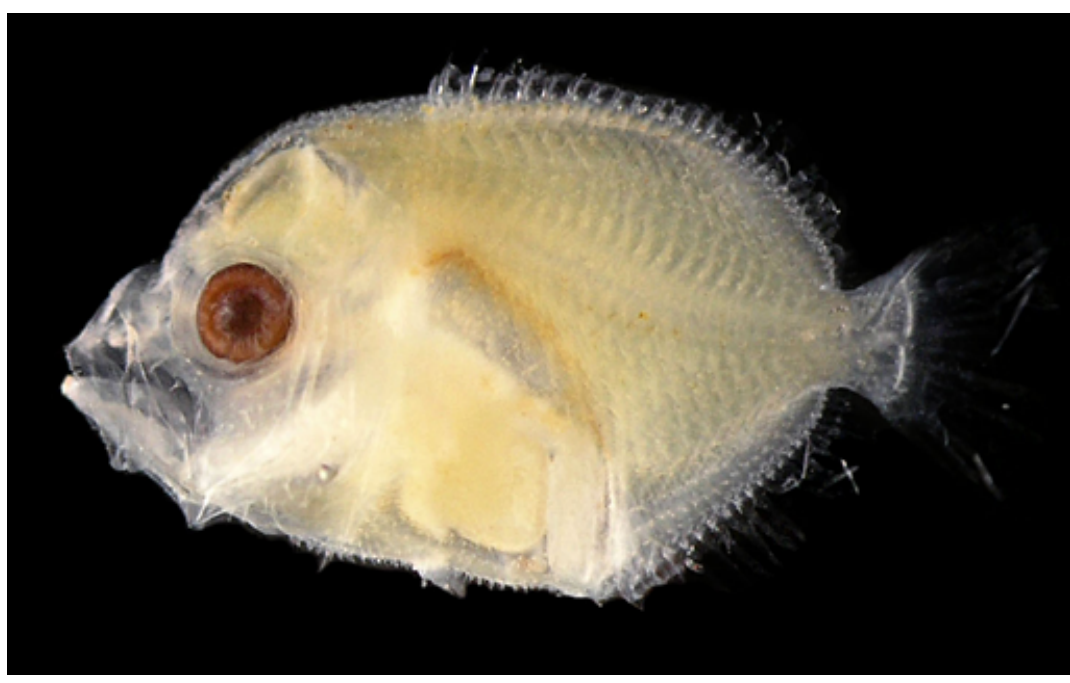

Figura 122 - B: DZUFRJ 352; Flexão; CP 4,8 mm. da vesícula gasosa e do intestino são bem visíveis. Ao longo do desenvolvimento, pequenos espinhos se desenvolvem na cabeça e no corpo. Apresentam melanóforos na cabeça dispersos anterior e posteriormente. A margem da mandíbula é pigmentada. Na margem dorsal do corpo há uma linha simples de melanóforos, começando no terceiro ou quarto miômero, estendendo-se até o $15^{\circ}$. Ao longo da linha lateral, melanóforos estão presentes entre o oitavo e o $15^{\circ}$ miômero. As nadadeiras dorsal e anal apresentam pigmentação acima e abaixo dos miômeros 14 e 15 e melanóforos espalhados na membrana entre os espinhos da nadadeira dorsal. Possui 24 miômeros. Nadadeira dorsal: XIV-XV, 15-17. Nadadeira anal: III, 17.

Tamanho: pré-flexão 3,0 mm; flexão 4,0-5,0 mm; pós-flexão 8,0-8,2 mm; transformação 10,5 mm.

Habitat: espécie marinha, demersal, associada a formações coralinas, ocorre em águas tropicais até $200 \mathrm{~m}$ de profundidade.

Nome vulgar: Anjo dorso de fogo. 


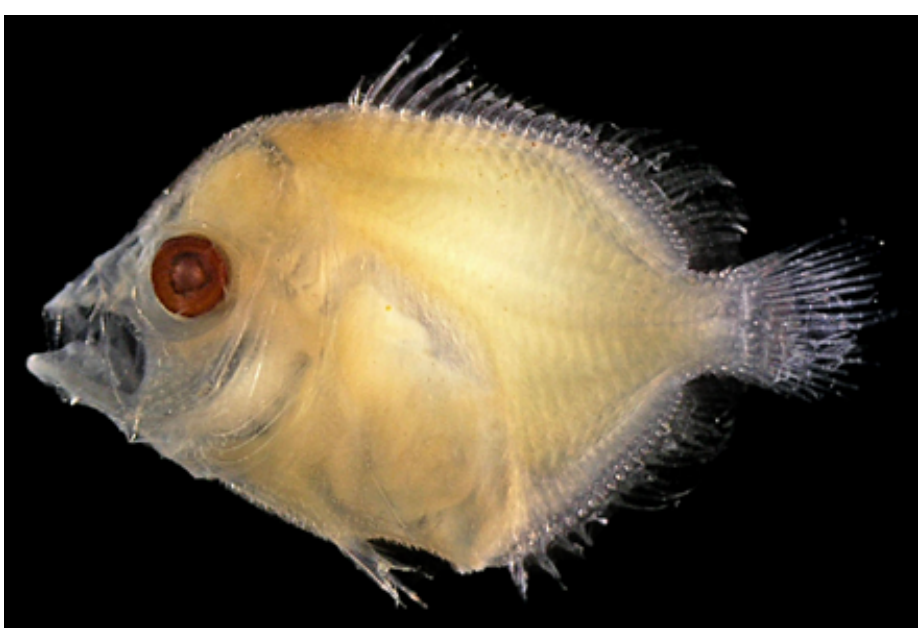

Figura 122 - C: DZUFRJ 1171; Pós-flexão; CP 8,2 mm.

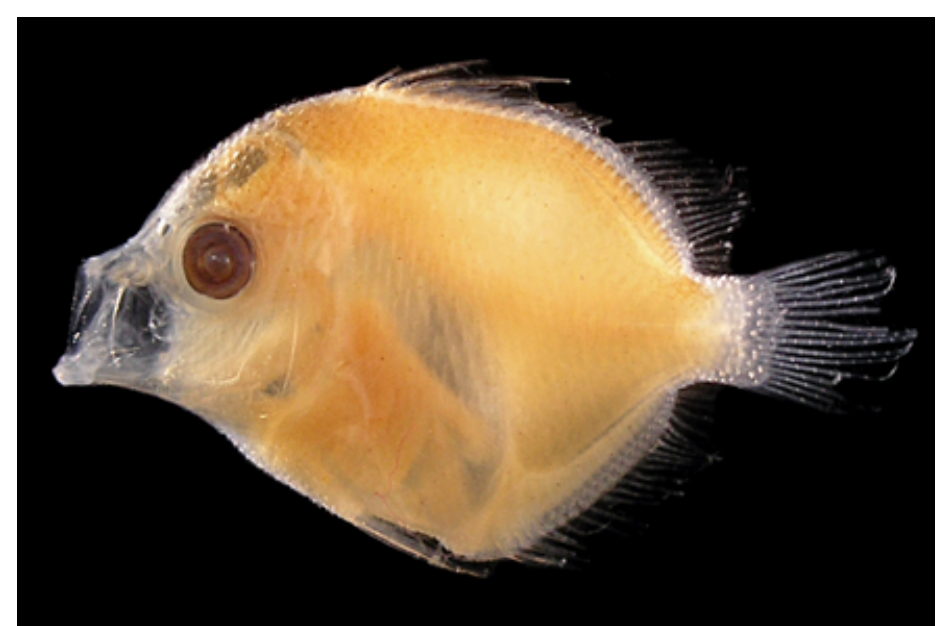

Figura 122 - D: DZUFRJ 7509; Transformação; CP 10,5 mm.

\section{Georreferenciamento}

\begin{tabular}{|c|c|c|c|c|c|c|c|c|}
\hline DZUFRJ & Latitude (S) & Longitude (W) & Data & $\begin{array}{l}\text { Tipo de } \\
\text { arrasto }\end{array}$ & $\begin{array}{c}\text { Profundidade } \\
\text { de coleta }\end{array}$ & Rede & $\begin{array}{c}\text { Malha } \\
(\mu \mathrm{m})\end{array}$ & $\begin{array}{l}\text { No. de } \\
\text { inds. }\end{array}$ \\
\hline 352 & 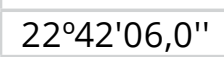 & $040^{\circ} 14^{\prime} 26,0^{\prime \prime}$ & 02 & oblíquo & $50 \mathrm{~m}$ & & 330 & 2 \\
\hline 357 & 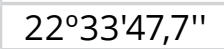 & -1 & $17 / 05$ & obl & $50 \mathrm{~m}$ & & & 1 \\
\hline 1171 & & & $10 / 05$ & & & cilíndri & & 1 \\
\hline 1226 & 22 & 9०49'41,2" & $12 / 0$ & $\mathrm{obl}$ & $m$ & cilíndricc & 500 & 1 \\
\hline 7509 & $21^{\circ} 54^{\prime} 36,5^{\prime \prime}$ & $039^{\circ} 45^{\prime} 20,0^{\prime \prime}$ & 10/10/2001 & oblíquo & $1.000 \mathrm{~m}$ & cilíndrico-cônica & 500 & 1 \\
\hline 22406 & $22^{\circ} 08^{\prime} 01,8^{\prime \prime}$ & $039^{\circ} 37^{\prime} 30,8^{\prime \prime}$ & $03 / 12 / 2002$ & vertical & $200-500 m$ & cilíndrico-cônica & 500 & 1 \\
\hline
\end{tabular}

Referências: Menezes \& Figueiredo, 1985; Burgess, 2002b; Kelly, 2006b; Fahay, 2007. 


\section{Família Cirrhitidae}

A família Cirrhitidae é marinha e ocorre nos oceanos Atlântico tropical, Índico e Pacífico. A maioria das espécies ocorre no Indo-Pacífico. São encontradas em águas tropicais e costeiras e os adultos vivem associados a rochas e corais. Compreende 12 gêneros com aproximadamente 33 espécies.

São caracterizadas pelo corpo alongado, com focinho pontudo e um barbilhão na extremidade da maxila inferior. Essa característica é diagnóstica da família e o barbilhão aumenta de tamanho com o decorrer do desenvolvimento da larva.

No Brasil já foi identificada uma espécie nas fases de larva e adulto: Amblycirrhitus pinos (Mowbray, 1927). Nesse estudo é contemplada a espécie Amblycirrhitus pinos. 


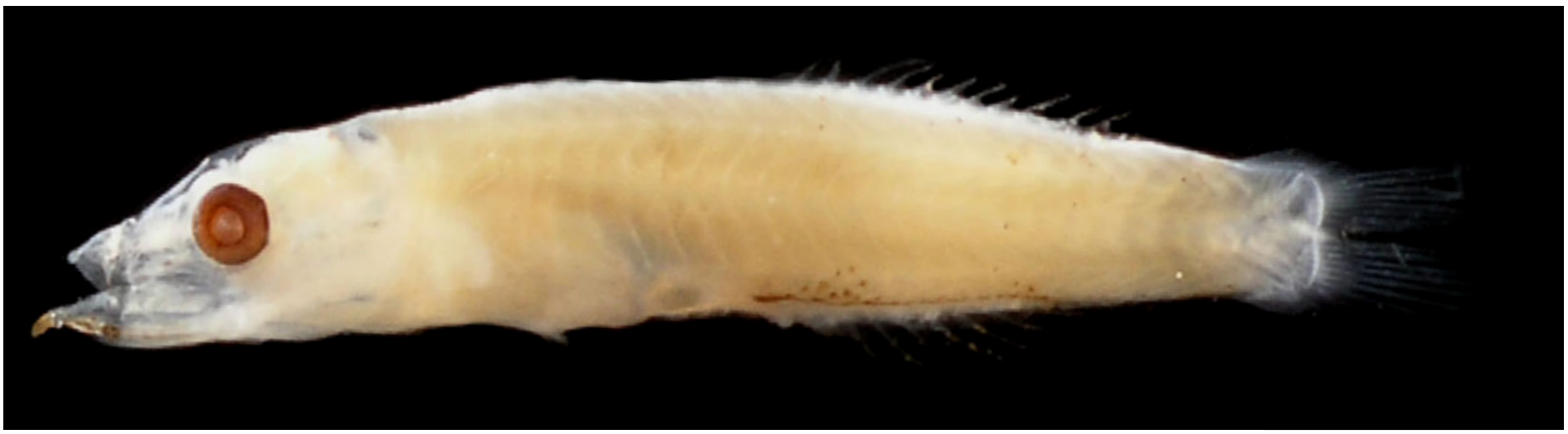

Figura 123 - A: Amblycirrhitus pinos. DZUFRJ 16055; Flexão; CP 4,9 mm.

\section{Amblycirrhitus pinos (Mowbray, 1927)}

O corpo é inicialmente alongado (26 miômeros) e lateralmente comprimido. Com o crescimento o corpo e o pedúnculo caudal tornam-se mais altos. A cabeça possui tamanho moderado e o focinho é pontudo. A

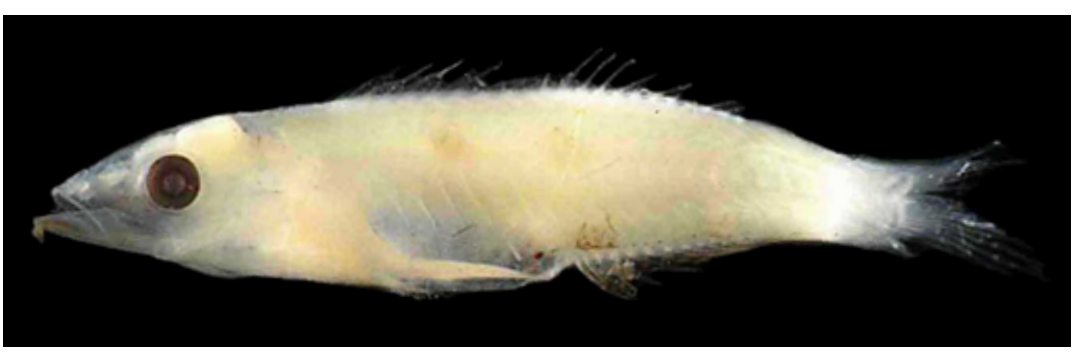

Figura 123 - B: DZUFRJ 341; Pós-flexão; CP 10,0 mm.

boca é terminal e na maxila inferior encontra-se um barbilhão pigmentado que se desenvolve a medida que a larva cresce. O intestino é longo e estreito. A origem da nadadeira pélvica é bem posterior à origem da nadadeira peitoral. No estágio de flexão existem poucos pigmentos espaIhados na margem ventral do corpo, começando a organizar-se em blocos. No estágio de pós-flexão formam-se várias bandas de pigmento no corpo, sempre associadas aos ângulos superior e inferior dos miosseptos. Outros melanóforos estão presentes no dorso da cabeça e focinho. As membranas que cobrem os espinhos e raios das nadadeiras dorsal e anal são pigmentadas.

Tamanho: flexão 4,9-7,5 mm; pós-flexão 8,0-10,0 mm.

Habitat: espécie marinha, demersal, ocorre em águas tropicais próximo a rochas e a formações coralinas até $46 \mathrm{~m}$ de profundidade.

Nome vulgar: Pinos.

\section{Georreferenciamento}

\begin{tabular}{|c|c|c|c|c|c|c|c|c|}
\hline DZUFRJ & Latitude (S) & Longitude (W) & Data & $\begin{array}{c}\text { Tipo de } \\
\text { arrasto }\end{array}$ & $\begin{array}{c}\text { Profundidade } \\
\text { de coleta }\end{array}$ & Rede & $\begin{array}{c}\text { Malha } \\
(\boldsymbol{\mu m})\end{array}$ & $\begin{array}{c}\mathbf{N}^{\circ} \text {. de } \\
\text { inds. }\end{array}$ \\
\hline 635 & $22^{\circ} 36^{\prime} 54,9^{\prime \prime}$ & $040^{\circ} 09^{\prime} 19,4^{\prime \prime}$ & $16 / 05 / 2002$ & oblíquo & $50 \mathrm{~m}$ & bongô & 330 & 1 \\
\hline 698 & $22^{\circ} 37^{\prime} 355^{\prime \prime}$ & $040^{\circ} 09^{\prime} 32,8^{\prime \prime}$ & $16 / 05 / 2002$ & oblíquo & $1.000 \mathrm{~m}$ & cilíndrico-cônica & 500 & 1 \\
\hline 1224 & $22^{\circ} 02^{\prime} 30,0^{\prime \prime}$ & $039^{\circ} 49^{\prime} 41,2^{\prime \prime}$ & $12 / 05 / 2002$ & oblíquo & $1.000 \mathrm{~m}$ & cilíndrico-cônica & 500 & 1 \\
\hline 1233 & $22^{\circ} 03^{\prime} 21,7^{\prime \prime}$ & $039^{\circ} 45^{\prime} 11,9^{\prime \prime}$ & $12 / 05 / 2002$ & oblíquo & $1.000 \mathrm{~m}$ & cilíndrico-cônica & 500 & 1 \\
\hline 1275 & $22^{\circ} 06^{\prime} 37,8^{\prime \prime}$ & $039^{\circ} 49^{\prime} 44,8^{\prime \prime}$ & $10 / 05 / 2002$ & oblíquo & até a termoclina & bongô & 500 & 1 \\
\hline 1297 & $22^{\circ} 02^{\prime} 30,0^{\prime \prime}$ & $039^{\circ} 49^{\prime} 41,2^{\prime \prime}$ & $12 / 05 / 2002$ & oblíquo & até a termoclina & bongô & 500 & 2 \\
\hline 1315 & $22^{\circ} 08^{\prime} 14,9^{\prime \prime}$ & $039^{\circ} 46^{\prime} 34,6^{\prime \prime}$ & $11 / 05 / 2002$ & oblíquo & até a termoclina & bongô & 500 & 3 \\
\hline 1361 & $22^{\circ} 02^{\prime} 30,0^{\prime \prime}$ & $039^{\circ} 49^{\prime} 41,2^{\prime \prime}$ & $12 / 05 / 2002$ & oblíquo & até a termoclina & bongô & 330 & 1 \\
\hline 1384 & $22^{\circ} 08^{\prime} 14,9^{\prime \prime}$ & $039^{\circ} 46^{\prime} 34,6^{\prime \prime}$ & $11 / 05 / 2002$ & oblíquo & até a termoclina & bongô & 330 & 1 \\
\hline
\end{tabular}

Referências: Watson, 1996f; Randall, 2002b; Criales, 2006; Fahay, 2007. 


\section{Família Mugilidae}

A família Mugilidae é marinha e costeira ou estuarina e migra além da plataforma continental para reprodução. É representada por 17 gêneros, com aproximadamente 72 espécies. Possui nadadeira dorsal separada, com IV espinhos e 8-10 raios. A anal é formada por II - III espinhos e 7-11 raios. É caracterizada pela nadadeira pélvica subabdominal.

No Brasil já foram identificadas dez espécies nas fases de larva e adulto. Nesse estudo é contemplada a espécie Mugil curema. 


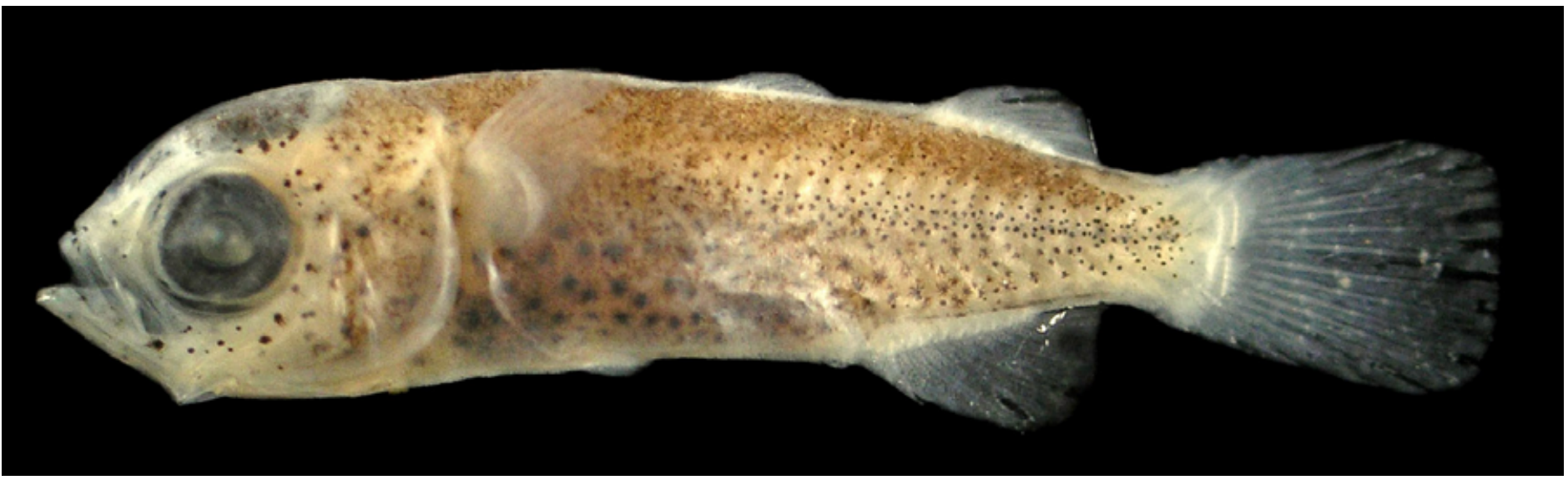

Figura 124 - A: Mugil curema. A. DZUFRJ 33543; Pós-flexão; CP 6,0 mm.

\section{Mugil curema Valenciennes, 1836}

O corpo é relativamente estreito e robusto, o intestino é grande e volumoso e corresponde até $70 \%$ do CP. É caracterizada por duas nadadeiras dorsais com base curta (quatro espinhos e oito raios). A nadadeira anal é formada por três espinhos e nove

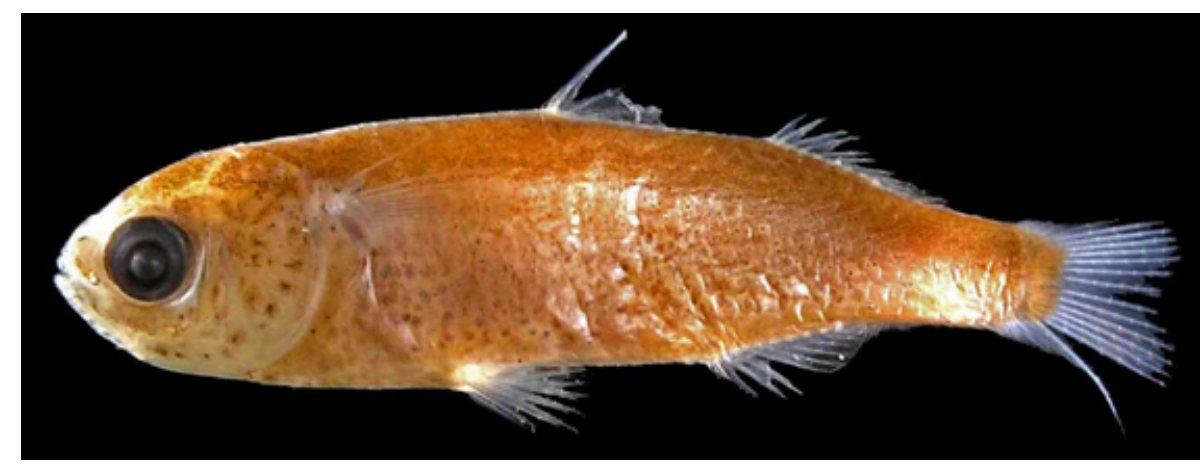

Figura 124 - B: DZUFRJ 24896; Transformação; CP 16,2 mm. raios, o que a separa das espécies Mugil cephalus, Mugil curvidens, Mugil liza, Mugil trichodon. Pode ser separada de Mugil incilis pela posição da origem da segunda nadadeira dorsal ao longo da base da anal. A pigmentação é muito evidente na região dorsal da cabeça, seguindo até a base da segunda nadadeira dorsal. A região dorsal do intestino e a margem ventral do corpo (entre o ânus e a base da nadadeira caudal) são muito pigmentadas. Em pós-flexão e transformação a larva é muito escura na maior parte do corpo. Número total de miômeros: 24.

Tamanho: pós-flexão 6,0-8,0 mm; transformação 16,2 mm.

Habitat: espécie marinha, pelágica, ocorre em águas subtropicais. Vivem em regiões costeiras ou estuarinas até $15 \mathrm{~m}$ de profundidade.

Nome vulgar: Tainha pratiqueira.

Georreferenciamento

\begin{tabular}{|c|c|c|c|c|c|c|c|c|}
\hline DZUFRJ & Latitude (S) & Longitude (W) & Data & $\begin{array}{l}\text { Tipo de } \\
\text { arrasto }\end{array}$ & $\begin{array}{c}\text { Profundidade } \\
\text { de coleta }\end{array}$ & Rede & $\begin{array}{l}\text { Malha } \\
(\mu \mathrm{m})\end{array}$ & $\begin{array}{l}N^{\circ} \text {. de } \\
\text { inds. }\end{array}$ \\
\hline 24895 & $22^{\circ} 2$ & $47^{\prime}$ & $16 / 0$ & horizontal & superfície & nêl & 500 & 2 \\
\hline 24896 & $22^{\circ} 36,08^{\prime}$ & $039^{\circ} 54,39^{\prime}$ & $15 / 06 / 2003$ & horizontal & superfície & nêuston & 500 & 1 \\
\hline
\end{tabular}

Referências: Monteiro_Ribas \& Bonecker, 2001; Ditty et al., 2006c; Fahay, 2007. 


\section{Família Pomacentridae}

A família Pomacentridae é marinha e ocorre em todos os mares tropicais. Compreende 28 gêneros com aproximadamente 348 espécies. Algumas espécies são encontradas também em regiões temperadas e muito poucas podem viver em águas salobras e doces. Ocorre em águas costeiras, de baixa profundidade, associada a rochas ou formações coralinas. As larvas são alongadas até a flexão da notocorda. A medida que a larva cresce o corpo torna-se alto. O intestino enrola-se adquirindo um formato triangular e curto, muito pigmentado. Uma pequena vesícula gasosa está localizada anteriormente a massa visceral. Apresenta poucos espinhos na cabeça (com exceção da subfamília Chrominae), região suborbital serrilhada, presença de um pequeno espinho opercular e alguns pequenos espinhos pré-operculares e supracleitral. Possui boca pequena e linha lateral incompleta. Nadadeira anal: II, 9-15. Nadadeira dorsal contínua: XII-XIII, 11-17.

No Brasil já foram identificadas 16 espécies nas fases de larva e adulto. Nesse estudo são contempladas as espécies Abudefduf saxatilis, Stegastes leucostictus e Microspathodon chrysurus. 


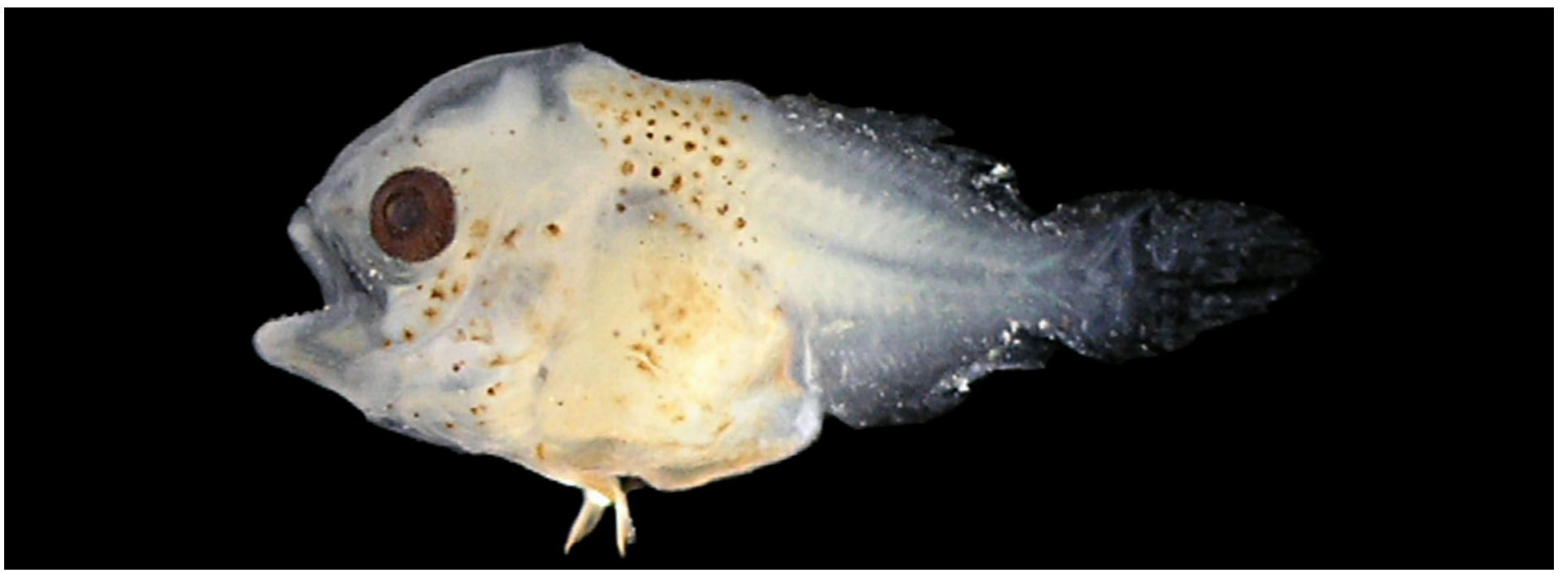

Figura 125 - Abudefduf saxatilis. DZUFRJ 388; Flexão; CP 3,5 mm.

\section{Abudefduf saxatilis (Linnaeus, 1758)}

O corpo é inicialmente alongado (26 miômeros) e lateralmente comprimido, tornando-se alto após a flexão. A cabeça também é alta e o focinho é arredondado. O intestino enrola-se adquirindo um formato triangular e curto, muito pigmentado. Possui melanóforos na porção ventral da massa visceral, o que separa essa espécie das demais. No estágio de flexão, a porção anterior do corpo é muito pigmentada, concentrando-se na área do opérculo, cabeça e sobre o intestino. O pedúnculo caudal não tem pigmentos. Nadadeira dorsal: XIII, 12-13. Nadadeira anal: II, 12-13.

Tamanho: flexão 3,5 mm.

Habitat: espécie marinha, demersal, ocorre em águas subtropicais até $15 \mathrm{~m}$ de profundidade. Vive associada a formações coralinas e rochas.

Nome vulgar: Sargento.

\section{Georreferenciamento}

\begin{tabular}{|c|c|c|c|c|c|c|c|c|}
\hline DZUFRJ & Latitude (S) & Longitude (W) & Data & $\begin{array}{c}\text { Tipo de } \\
\text { arrasto }\end{array}$ & $\begin{array}{c}\text { Profundidade } \\
\text { de coleta }\end{array}$ & Rede & $\begin{array}{c}\text { Malha } \\
\left.\text { ( } \boldsymbol{\mu m}^{2}\right)\end{array}$ & $\begin{array}{c}\mathbf{N}^{\circ} \text {. de } \\
\text { inds. }\end{array}$ \\
\hline 388 & $22^{\circ} 31^{\prime} 27,0^{\prime \prime}$ & $040^{\circ} 16^{\prime} 56,0^{\prime \prime}$ & $17 / 05 / 2002$ & oblíquo & $600 \mathrm{~m}$ & cilíndrico-cônica & 500 & 1 \\
\hline
\end{tabular}

Referências: Menezes \& Figueiredo, 1985; Watson, 1996g; Carter, 2002; Fahay, 2007. 


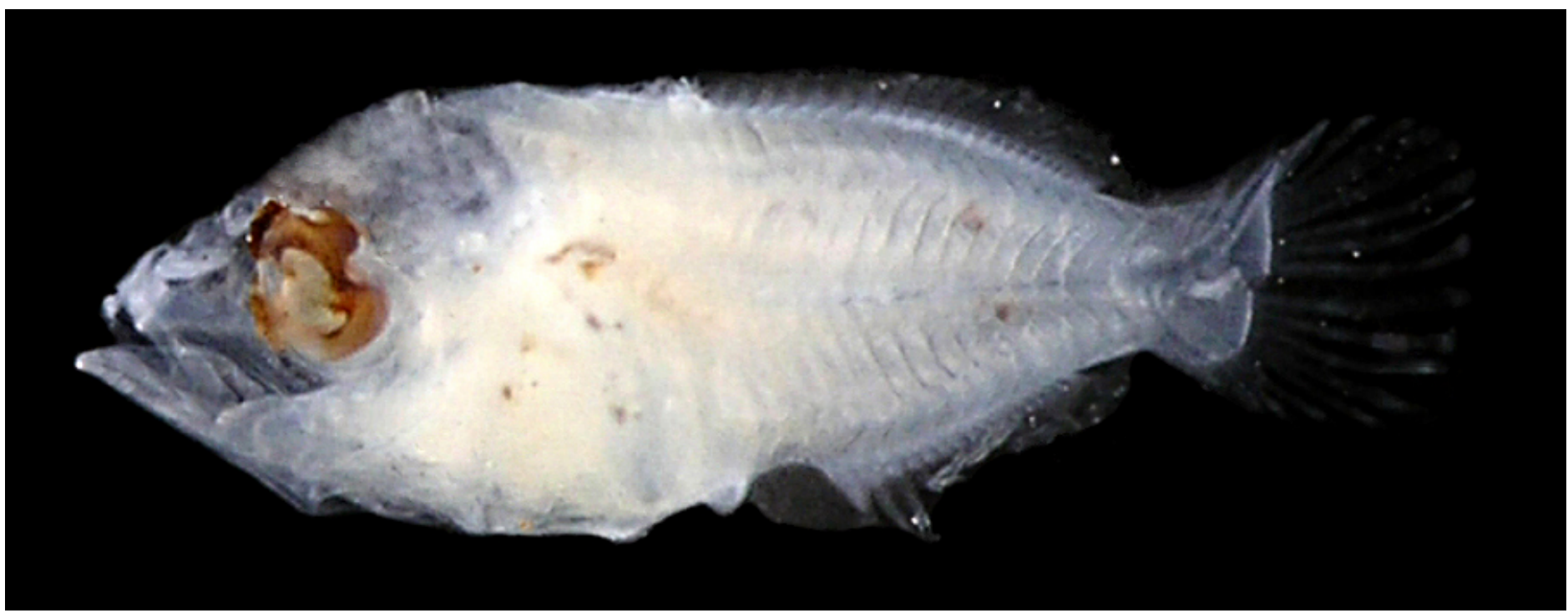

Figura 126: Microspathodon chrysurus. DZUFRJ 22408; Flexão; CP 3,8 mm.

\section{Microspathodon chrysurus (Cuvier, 1830)}

Desde a pré-flexão possui pigmentos espalhados pela membrana entre os raios da nadadeira peitoral. Forte pigmentação na metade da cabeça e na nuca. Tem melanóforos distribuídos na porção anterior da massa visceral e no cleitro. Possui manchas internas de melanóforos na porção mediano-dorsal e mediano-ventral. A nadadeira pélvica apresenta pigmentos nos raios antes da flexão da notocorda. Número total de miômeros: 26.

Tamanho: flexão 3,8-4,6 mm.

Habitat: espécie marinha, demersal, ocorre em águas subtropicais até $120 \mathrm{~m}$ de profundidade, mas normalmente é encontrada a $10 \mathrm{~m}$. Vive próximo ao topo ou exterior de cavernas e frestas, sendo abundante em regiões de formações coralinas.

Nome vulgar: Donzela azul.

Georreferenciamento

\begin{tabular}{|c|c|c|c|c|c|c|c|c|}
\hline DZUFR & Latitude (S) & Longitude (W) & Data & $\begin{array}{c}\text { Tipo de } \\
\text { arrasto }\end{array}$ & $\begin{array}{c}\text { Profundidade } \\
\text { de coleta }\end{array}$ & Rede & $\begin{array}{c}\text { Malha } \\
\text { ( } \boldsymbol{\mu m} \text { ) }\end{array}$ & $\begin{array}{c}\text { No. de } \\
\text { inds. }\end{array}$ \\
\hline 492 & $22^{\circ} 33^{\prime} 45,8^{\prime \prime}$ & $040^{\circ} 13^{\prime} 22,9^{\prime \prime}$ & $17 / 05 / 2002$ & oblíquo & $800 \mathrm{~m}$ & cilíndrico-cônica & 500 & 1 \\
\hline 22408 & $22^{\circ} 07^{\prime} 58,8^{\prime \prime}$ & $039^{\circ} 49^{\prime} 08,9^{\prime \prime}$ & $01 / 12 / 2002$ & vertical & $0-50 \mathrm{~m}$ & cilíndrico-cônica & 500 & 1 \\
\hline
\end{tabular}

Referências: Menezes \& Figueiredo, 1985; Watson, 1996g; Carter, 2002; Fahay, 2007. 


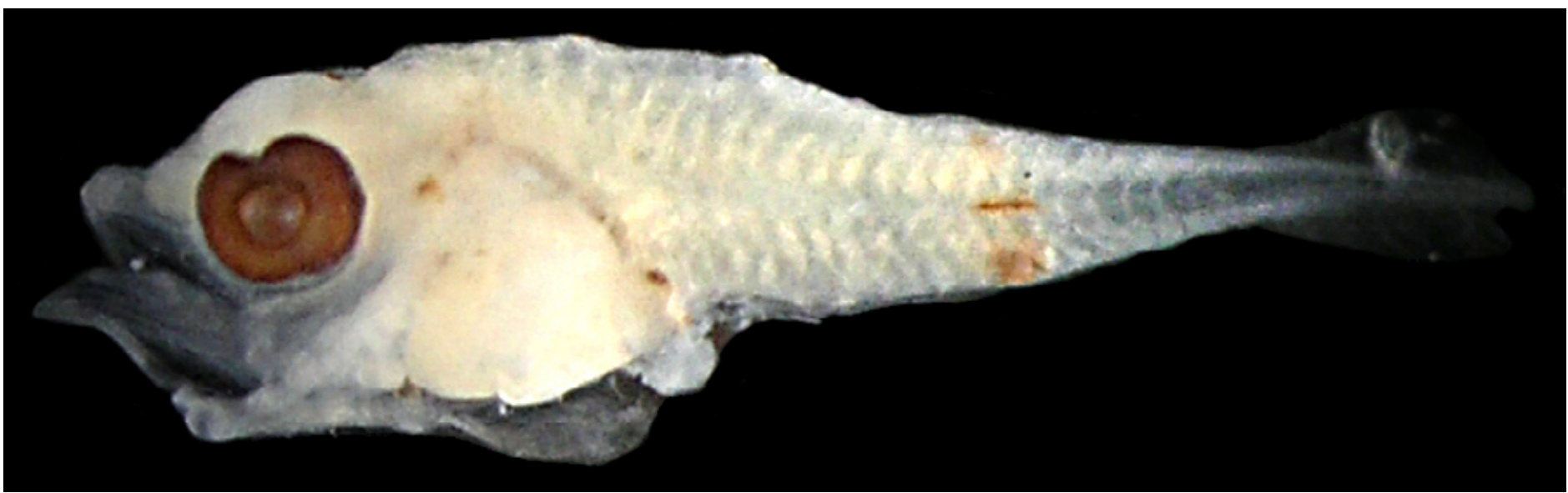

Figura 127 - A: Stegastes leucostictus. DZUFRJ 383; Pré-flexão; CP 2,5 mm.

\section{Stegastes leucostictus (Müller \& Troschel, 1848)}

Essa espécie se difere de outros pomacentrídeos pela combinação de características merísticas e pelo padrão de pigmentação. As larvas em pré-flexão apresentam poucos melanóforos na porção posterior da cabeça, uma linha ventral de pigmentos no corpo e na base da notocorda. Em flexão, possuem pigmentos na linha lateral com poucas manchas mediano-dorsais claras, além de forte pigmentação na margem dorsal da massa visceral. No estágio de pós-flexão a primeira nadadeira dorsal e a peitoral são pigmentadas, enquanto a segunda dorsal e a anal não possuem pigmentos. Em todos os estágios não há pigmentação no pedúnculo caudal e nem no focinho. Número total de miômeros: 26.

Tamanho: pré-flexão 2,1-2,8 mm; flexão 4,6-4,8 mm; pós-flexão 5,0 mm.

Habitat: espécie marinha, demersal, ocorre em águas

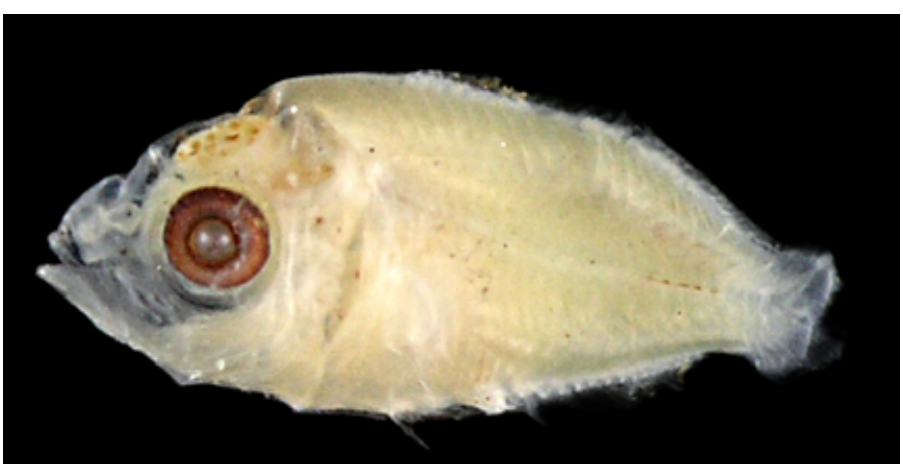

Figura 127 - B: DZUFRJ 392; Flexão; CP 4,8 mm.

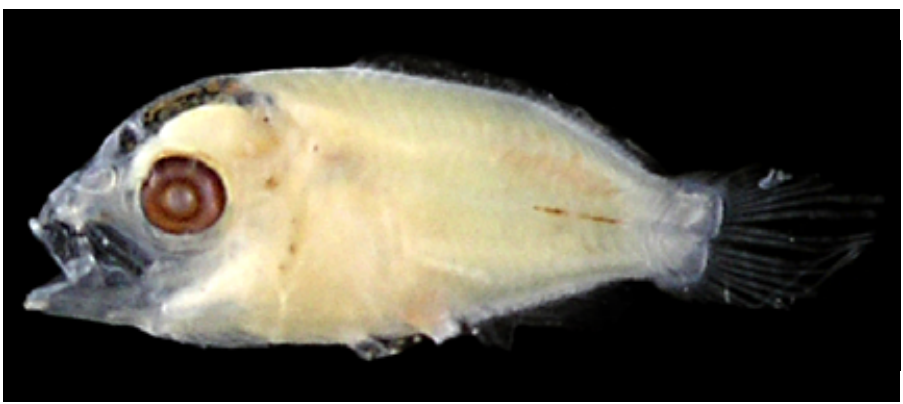

Figura 127 - C: DZUFRJ 5027; Pós-flexão; CP 5,0 mm. tropicais até $10 \mathrm{~m}$ de profundidade. Vive próximo a gramas marinhas, formações coralinas e rochas, podendo ser encontrada também em áreas de mangue.

\section{Georreferenciamento}

\begin{tabular}{|c|c|c|c|c|c|c|c|c|}
\hline DZUFR & Latitude (S) & Longitude (W) & Data & $\begin{array}{c}\text { Tipo de } \\
\text { arrasto }\end{array}$ & $\begin{array}{c}\text { Profundidade } \\
\text { de coleta }\end{array}$ & Rede & $\begin{array}{c}\text { Malha } \\
\text { ( } \boldsymbol{\mu m} \text { ) }\end{array}$ & $\begin{array}{c}\text { No. de } \\
\text { inds. }\end{array}$ \\
\hline 383 & $22^{\circ} 31^{\prime} 27,0^{\prime \prime}$ & $040^{\circ} 16^{\prime} 56,0^{\prime \prime}$ & $17 / 05 / 2002$ & oblíquo & $600 \mathrm{~m}$ & cilíndrico-cônica & 500 & 3 \\
\hline 387 & $22^{\circ} 36^{\prime} 54,9^{\prime \prime}$ & $040^{\circ} 09^{\prime} 19,4^{\prime \prime}$ & $16 / 05 / 2002$ & oblíquo & $50 \mathrm{~m}$ & bongô & 500 & 1 \\
\hline 391 & $22^{\circ} 32^{\prime} 03,0^{\prime \prime}$ & $040^{\circ} 17^{\prime} 21,0^{\prime \prime}$ & $19 / 05 / 2002$ & oblíquo & $30 \mathrm{~m}$ & bongô & 330 & 1 \\
\hline 392 & $22^{\circ} 41^{\prime} 544^{\prime \prime}$ & $040^{\circ} 14^{\prime} 04,5^{\prime \prime}$ & $16 / 05 / 2002$ & oblíquo & $1.000 \mathrm{~m}$ & cilíndrico-cônica & 500 & 1 \\
\hline 22198 & $22^{\circ} 33^{\prime} 477^{\prime \prime}$ & $040^{\circ} 12^{\prime} 20,5^{\prime \prime}$ & $17 / 05 / 2002$ & oblíquo & $50 \mathrm{~m}$ & bongô & 330 & 1 \\
\hline
\end{tabular}

Referências: Menezes \& Figueiredo, 1985; Watson, 1996g; Carter, 2002; Fahay, 2007. 


\section{Família Labridae}

A família Labridae é marinha e ocorre nos oceanos Atlântico, Índico e Pacífico. Compreende aproximadamente 68 gêneros e 453 espécies. É dominante na ictiofauna que vive associada à corais e comunidades de gramas marinhas, em regiões tropicais. Vive em todos os ambientes tropicais do mundo e é uma das famílias mais diversificadas, em relação à coloração, ao formato e tamanho do corpo.

As larvas de Labridae são tipicamente alongadas, comprimidas lateralmente e possuem uma única nadadeira dorsal que se origina sobre a base da peitoral ou atrás da cabeça. O pedúnculo caudal é alto e o intestino é rugoso estendendo-se até metade do corpo. Não apresenta espinho na cabeça. O formato dos olhos é variável e pode ter uma massa ventral de tecido coroide despigmentado. As larvas no estágio de pré-flexão frequentemente possuem melanóforos na membrana embrionária, enquanto que a maioria das larvas em pós-flexão tem pouca ou nenhuma pigmentação.

No Brasil já foram identificadas 18 espécies nas fases de larva e adulto. Nesse estudo são contempladas as espécies Halichoeres maculipina e Thalassoma noronhanum. 


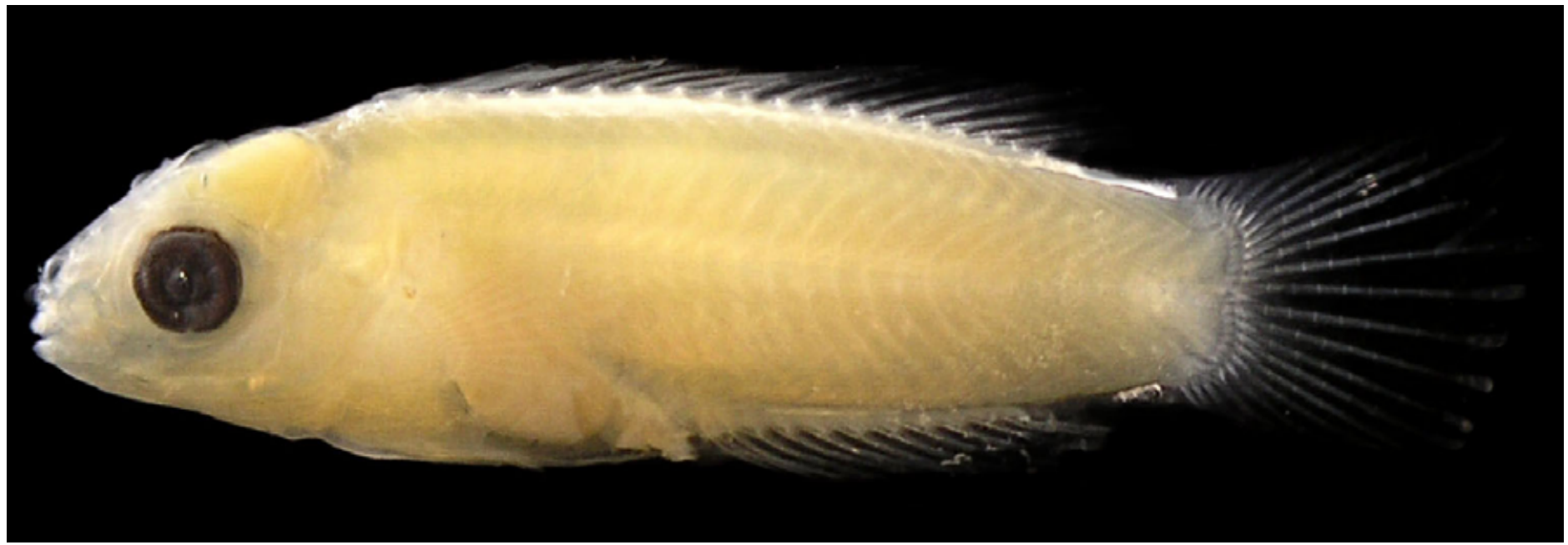

Figura 128: Halichoeres maculipinna. DZUFRJ 11898; Pós-flexão; CP 8,9mm.

\section{Halichoeres maculipinna (Müller \& Troschel, 1848)}

O corpo é alongado (25 miômeros), comprimido lateralmente e mais alto na região peitoral; o pedúnculo caudal é alto. A cabeça é pequena com um focinho pontudo, olho arredondado e boca mediana. Nadadeira dorsal: IX, 11. Nadadeira anal: III, 11. A nadadeira peitoral é formada por 14 raios. A ausência de pigmentos pelo corpo é característica da espécie. A pigmentação se restringe a uma mancha de melanóforos sobre o intestino (próximo ao ânus) e alguns pigmentos associados a porção posterior dos raios das nadadeiras dorsal e anal.

Tamanho: pós-flexão 7,0-9,5 mm.

Habitat: espécie marinha, demersal, ocorre em águas tropicais até $24 \mathrm{~m}$ de profundidade. Vive associada a formações coralinas, algas e áreas rochosas.

Nome vulgar: Budião palhaço.

\section{Georreferenciamento}

\begin{tabular}{|c|c|c|c|c|c|c|c|c|}
\hline DZUFRJ & Latitude (S) & Longitude (W) & Data & $\begin{array}{l}\text { Tipo de } \\
\text { arrasto }\end{array}$ & $\begin{array}{c}\text { Profundidade } \\
\text { de coleta }\end{array}$ & Rede & $\begin{array}{l}\text { Malha } \\
(\mu \mathrm{m})\end{array}$ & $\begin{array}{l}N^{\circ} \text {. de } \\
\text { inds. }\end{array}$ \\
\hline 499 & $22^{\circ} 38^{\prime} 25,0^{\prime \prime}$ & $040^{\circ} 17^{\prime} 41,0^{\prime \prime}$ & $19 / 05 / 2002$ & oblíquo & $40 \mathrm{~m}$ & bongô & 500 & 1 \\
\hline 508 & $22^{\circ} 31^{\prime} 27,0^{\prime \prime}$ & $040^{\circ} 16^{\prime} 56,0^{\prime \prime}$ & $17 / 05 / 2002$ & oblíquo & $600 \mathrm{~m}$ & cilíndrico-cônica & 500 & 1 \\
\hline 537 & $22^{\circ} 33^{\prime} 47,7^{\prime \prime}$ & $040^{\circ} 12^{\prime} 20,5^{\prime \prime}$ & $17 / 05 / 2002$ & oblíquo & $50 \mathrm{~m}$ & bongô & 330 & 1 \\
\hline
\end{tabular}

Referências: Menezes \& Figueiredo, 1985; Watson, 1996h; Westneat, 2002a; Jones et al., 2006a; Fahay, 2007. 


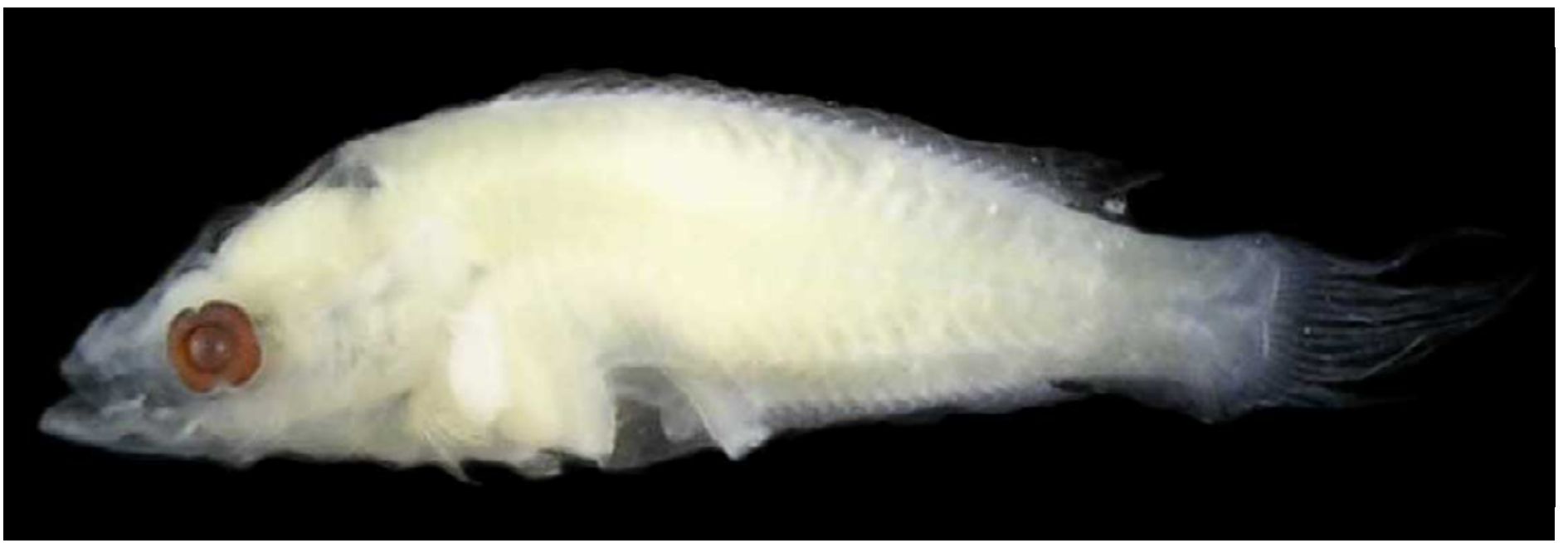

Figura 129: Thalassoma noronhanum. DZUFRJ 12057; Flexão; CP 4,8 mm.

\section{Thalassoma noronhanum (Boulenger, 1890)}

O corpo é alongado (25 miômeros), comprimido lateralmente, sendo mais alto na região peitoral; o pedúnculo caudal é alto. A cabeça é proporcionalmente grande em relação a outras espécies dessa família. A boca é muito pequena e o olho é arredondado.

Tamanho: flexão 4,8-6,5 mm.

Habitat: espécie marinha, demersal, ocorre em águas tropicais até $60 \mathrm{~m}$ de profundidade, mas normalmente é encontrada entre 2 e $5 \mathrm{~m}$. Vive associada a formações coralinas, esponjas ou conchas vazias.

Nome vulgar: Budião de Noronha.

\section{Georreferenciamento}

\begin{tabular}{|c|c|c|c|c|c|c|c|c|}
\hline DZUFR J & Latitude (S) & Longitude (W) & Data & $\begin{array}{c}\text { Tipo de } \\
\text { arrasto }\end{array}$ & $\begin{array}{c}\text { Profundidade } \\
\text { de coleta }\end{array}$ & Rede & $\begin{array}{c}\text { Malha } \\
\text { ( } \boldsymbol{\mu m} \text { ) }\end{array}$ & $\begin{array}{c}\mathbf{N}^{\circ} \text {. de } \\
\text { inds. }\end{array}$ \\
\hline 368 & $22^{\circ} 38^{\prime} 25,0^{\prime \prime}$ & $040^{\circ} 17^{\prime} 41,0^{\prime \prime}$ & $19 / 05 / 2002$ & oblíquo & $40 \mathrm{~m}$ & bongô & 500 & 1 \\
\hline 372 & $22^{\circ} 33^{\prime} 477^{\prime \prime}$ & $040^{\circ} 12^{\prime} 20,5^{\prime \prime}$ & $17 / 05 / 2002$ & oblíquo & $50 \mathrm{~m}$ & bongô & 500 & 1 \\
\hline
\end{tabular}

Referências: Menezes \& Figueiredo, 1985; Westneat, 2002a; Jones et al., 2006a; Fahay, 2007. Thalassoma noronhanum. DZUFRJ 12057; Flexão; CP 4,8 mm. 


\section{Família Scaridae}

A família Scaridae é marinha e ocorre principalmente nas regiões tropicais. Vive em áreas de formações coralinas. Apresenta distribuição circumtropical, estando presente nos oceanos Atlântico, Pacífico e Índico. Compreende dez gêneros com 88 espécies.

A separação das espécies é difícil e ocorre, principalmente, quando adultos, devido à coloração específica. As larvas são alongadas, possuem corpo comprimido lateralmente e olhos elípticos nas fases inicias de desenvolvimento. Tem apenas uma nadadeira dorsal. O intestino é rugoso e estreito e se estende até metade do corpo. Não possui nenhum espinho na cabeça e a boca é pequena e sem dentes. A nadadeira dorsal é formada por IX espinhos flexíveis e 10 raios; a anal tem III-9. As larvas dos gêneros Cryptotomus, Scarus e Sparisoma podem ser separadas pelo padrão de pigmentação presente desde a pré-flexão. Nos três gêneros há melanóforos na região dorso-lateral do ânus e uma série de grandes melanóforos na região ventral do corpo.

No Brasil já foram identificadas 18 espécies nas fases de larva e adulto. Nesse estudo são contempladas as espécies Cryptotomus roseus, Scarus sp., Sparisoma sp. 


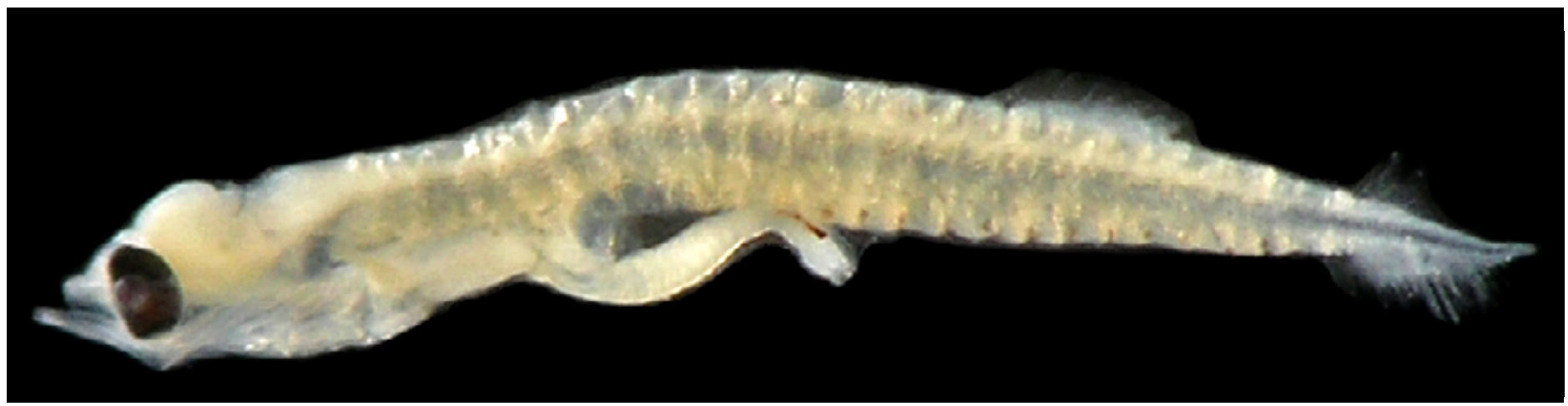

Figura 130 - A: Cryptotomus roseus. DZUFRJ 20050; Pré-flexão; CP 3,2 mm.

\section{Cryptotomus roseus \\ Cope, 1871}

A pigmentação está limitada a uma mancha na região dorso-lateral do ânus e a uma série de melanóforos ao longo da margem ventral da cauda, presentes desde o estágio de pré-flexão. A principal característica dessa espécie é a ausência de outros pigmentos no restante do corpo. Número total de miômeros: 25.

Tamanho: pré-flexão 2,5-3,2 mm; flexão 3,8-7,5 mm; pós-flexão 7,6-

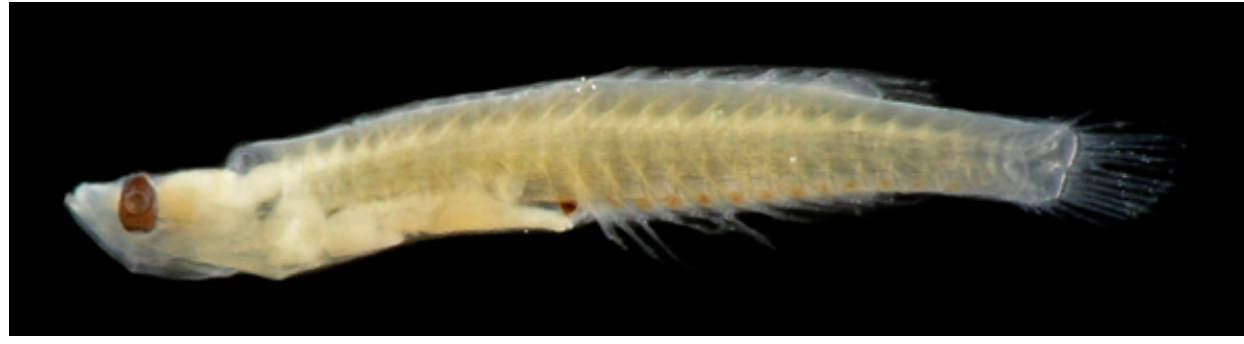

Figura 130 - B: DZUFRJ 17474; Flexão; CP 7,0 mm.

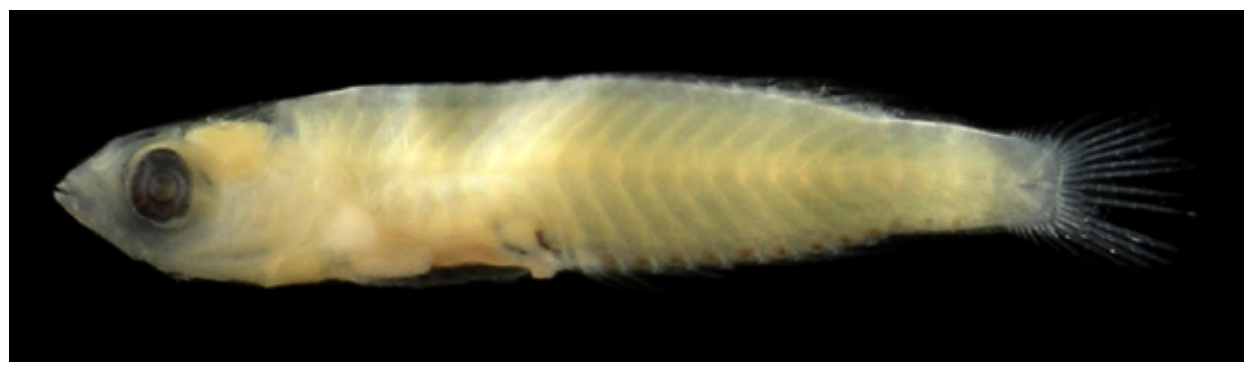

Figura 130 - C: DZUFRJ 17476; Pós-flexão; CP 8,2 mm. $10,0 \mathrm{~mm}$.

Habitat: espécie marinha, demersal, ocorre em águas tropicais até $60 \mathrm{~m}$ de profundidade. Vive em áreas de formações coralinas, associada à algas, gramas marinhas e substratos rochosos.

Nome vulgar: Periquito.

\section{Georreferenciamento}

\begin{tabular}{|c|c|c|c|c|c|c|c|c|}
\hline DZUFRJ & Latitude (S) & Longitude (W) & Data & $\begin{array}{l}\text { Tipo de } \\
\text { arrasto }\end{array}$ & $\begin{array}{c}\text { Profundidade } \\
\text { de coleta }\end{array}$ & Rede & $\begin{array}{c}\text { Malha } \\
(\mu \mathrm{m})\end{array}$ & $\begin{array}{l}N^{\circ} \text {. de } \\
\text { inds. }\end{array}$ \\
\hline 519 & $22^{\circ} 34^{\prime} 05,0^{\prime \prime}$ & $040^{\circ} 19^{\prime} 40,0^{\prime \prime}$ & $17 / 05 / 2002$ & oblíquo & $600 \mathrm{~m}$ & cilíndrico-cônica & 500 & 2 \\
\hline 7616 & 215'ㄴ, $10,4^{\prime \prime}$ & 03945'49,9" & 10/10/2001 & oblíquo & $1.000 \mathrm{~m}$ & cilíndrico-cônica & 500 & 2 \\
\hline 17474 & $22^{\circ} 07^{\prime} 29,0^{\prime \prime}$ & $039^{\circ} 06 ' 23,5^{\prime \prime}$ & $10 / 05 / 2002$ & oblíquo & $1.000 \mathrm{~m}$ & cilíndrico-cônica & 500 & 4 \\
\hline 17476 & $22^{\circ} 06^{\prime} 37,8^{\prime \prime}$ & $039^{\circ} 49^{\prime} 44,8^{\prime \prime}$ & $10 / 05 / 2002$ & oblíquo & té a termoclina & bongô & 500 & 3 \\
\hline 17486 & $22^{\circ} 32^{\prime} 49,0^{\prime \prime}$ & $040^{\circ} 04^{\prime} 20,9^{\prime \prime}$ & $07 / 11 / 2001$ & oblíquo & $1.000 \mathrm{~m}$ & cilíndrico-cônica & 500 & 1 \\
\hline 17487 & $22^{\circ} 32^{\prime} 49,0^{\prime \prime}$ & $040^{\circ} 04^{\prime} 20,9^{\prime \prime}$ & $07 / 11 / 2001$ & oblíquo & $1.000 \mathrm{~m}$ & cilíndrico-cônica & 500 & 7 \\
\hline 17495 & $22^{\circ} 32^{\prime} 49,0^{\prime \prime}$ & $040^{\circ} 04^{\prime} 20,9^{\prime \prime}$ & $07 / 11 / 2001$ & oblíquo & $1.000 \mathrm{~m}$ & cilíndrico-cônica & 500 & 1 \\
\hline 17498 & $22^{\circ} 32^{\prime} 50,0^{\prime \prime}$ & $040^{\circ} 04^{\prime} 09,9^{\prime \prime}$ & 06/11/2001 & oblíquo & $1.000 \mathrm{~m}$ & cilíndrico-cônica & 500 & 1 \\
\hline 20043 & $21^{\circ} 54^{\prime} 36,5^{\prime \prime}$ & $039^{\circ} 45^{\prime} 20,0^{\prime \prime}$ & 09/10/2001 & oblíquo & $1.000 \mathrm{~m}$ & cilíndrico-cônica & 500 & 2 \\
\hline
\end{tabular}




\begin{tabular}{|c|c|c|c|c|c|c|c|c|}
\hline DZUFRJ & Latitude (S) & Longitude (W) & Data & $\begin{array}{c}\text { Tipo de } \\
\text { arrasto }\end{array}$ & $\begin{array}{c}\text { Profundidade } \\
\text { de coleta }\end{array}$ & Rede & $\begin{array}{c}\text { Malha } \\
\text { ( } \boldsymbol{\mu m})\end{array}$ & $\begin{array}{c}\mathbf{N}^{\circ} \text {. de } \\
\text { inds. }\end{array}$ \\
\hline 20050 & $22^{\circ} 33^{\prime} 45,8^{\prime \prime}$ & $040^{\circ} 13^{\prime} 22,9^{\prime \prime}$ & $17 / 05 / 2002$ & oblíquo & $800 \mathrm{~m}$ & cilíndrico-cônica & 500 & 4 \\
\hline 20052 & $21^{\circ} 53^{\prime} 10,4^{\prime \prime}$ & $039^{\circ} 45^{\prime} 49,9^{\prime \prime}$ & $10 / 10 / 2001$ & oblíquo & $1.000 \mathrm{~m}$ & cilíndrico-cônica & 500 & 1 \\
\hline 20054 & $22^{\circ} 33^{\prime} 37,0^{\prime \prime}$ & $040^{\circ} 19^{\prime} 10,0^{\prime \prime}$ & $17 / 05 / 2002$ & oblíquo & $50 \mathrm{~m}$ & bongô & 500 & 8 \\
\hline 20057 & $2^{\circ} 58^{\prime} 31,0^{\prime \prime}$ & $039^{\circ} 50^{\prime} 29,7^{\prime \prime}$ & $10 / 10 / 2001$ & oblíquo & $1.000 \mathrm{~m}$ & cilíndrico-cônica & 500 & 4 \\
\hline 20058 & $2^{\circ} 58^{\prime} 31,0^{\prime \prime}$ & $039^{\circ} 50^{\prime} 29,7^{\prime \prime}$ & $10 / 11 / 2001$ & oblíquo & $1.000 \mathrm{~m}$ & cilíndrico-cônica & 500 & 1 \\
\hline 20061 & $21^{\circ} 58^{\prime} 31,0^{\prime \prime}$ & $039^{\circ} 50^{\prime} 29,7^{\prime \prime}$ & $10 / 10 / 2001$ & oblíquo & $1.000 \mathrm{~m}$ & cilíndrico-cônica & 500 & 2 \\
\hline 20062 & $2^{\circ} 54^{\prime} 36,5^{\prime \prime}$ & $039^{\circ} 45^{\prime} 20,0^{\prime \prime}$ & $10 / 10 / 2001$ & oblíquo & $1.000 \mathrm{~m}$ & cilíndrico-cônica & 500 & 2 \\
\hline 20065 & $21^{\circ} 54^{\prime} 36,5^{\prime \prime}$ & $039^{\circ} 45^{\prime} 20,0^{\prime \prime}$ & $10 / 10 / 2001$ & oblíquo & $1.000 \mathrm{~m}$ & cilíndrico-cônica & 500 & 2 \\
\hline 20069 & $21^{\circ} 57^{\prime} 10,5^{\prime \prime}$ & $039^{\circ} 43^{\prime} 33,3^{\prime \prime}$ & $09 / 10 / 2001$ & oblíquo & $1.000 \mathrm{~m}$ & cilíndrico-cônica & 500 & 1 \\
\hline
\end{tabular}

Referências: Menezes \& Figueiredo, 1985; Watson, 1996i; Westneat, 2002b; Jones et al., 2006b; Fahay, 2007. 


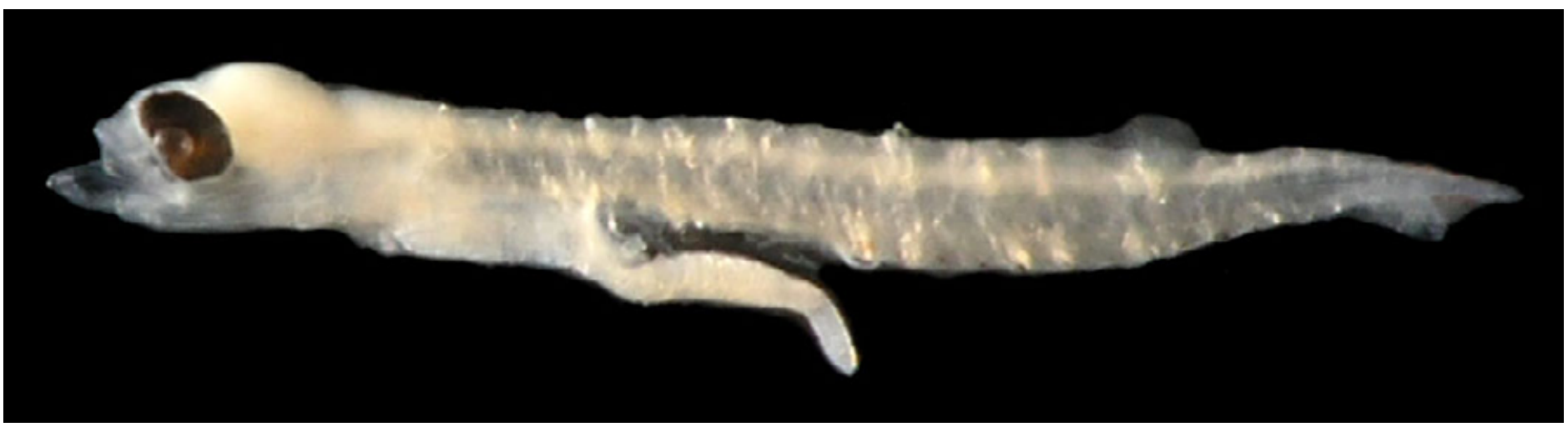

Figura 131 - A: Scarus sp. DZUFRJ 514; Pré-flexão; CP 3,2 mm.

\section{Scarus sp.}

A principal característica que permite a separação desse gênero, desde o estágio de pré-flexão, é a presença de pigmentos na margem dorsal do pedúnculo caudal formando uma linha. Possui melanóforos na região dorso-lateral

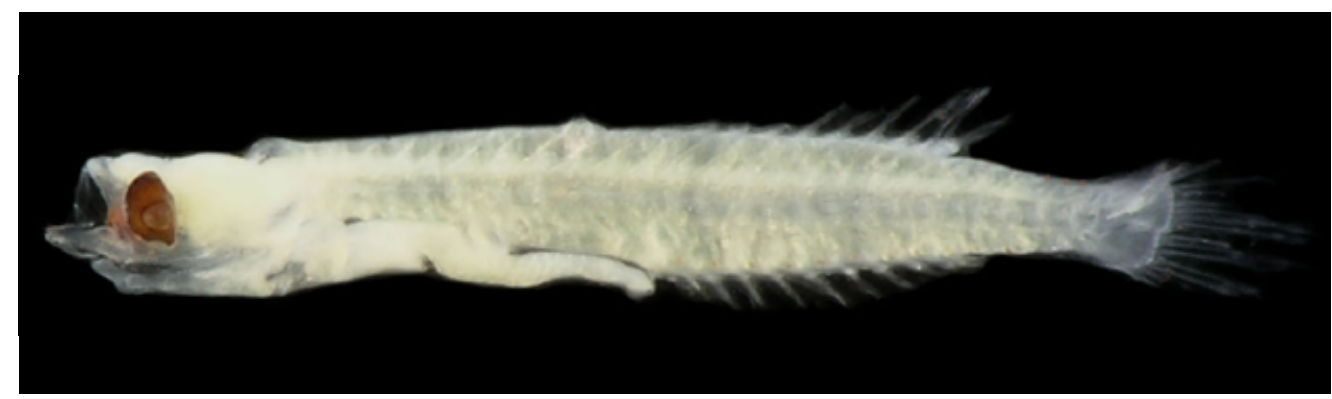

Figura 131 - B: DZUFRJ 20070; Flexão; CP 4,0 mm. do ânus e uma série ao longo da margem ventral da cauda. Número total de miômeros: 25.

Tamanho: pré-flexão 2,6-3,5 mm; flexão 3,5-5,0 mm.

Habitat: as espécies de Scarus são marinhas e demersais. Vivem em áreas de formações coralinas, associadas a algas, gramas marinhas e substratos rochosos. No Brasil já foram registradas seis espécies de Scarus.

\section{Georreferenciamento}

\begin{tabular}{|c|c|c|c|c|c|c|c|c|}
\hline DZUFRJ & Latitude (S) & Longitude (W) & Data & $\begin{array}{c}\text { Tipo de } \\
\text { arrasto }\end{array}$ & $\begin{array}{c}\text { Profundidade } \\
\text { de coleta }\end{array}$ & Rede & $\begin{array}{c}\text { Malha } \\
\text { ( } \boldsymbol{\mu m} \text { ) }\end{array}$ & $\begin{array}{c}\text { No. de } \\
\text { inds. }\end{array}$ \\
\hline 514 & $22^{\circ} 31^{\prime} 27,0^{\prime \prime}$ & $040^{\circ} 16^{\prime} 56,0^{\prime \prime}$ & $17 / 05 / 2002$ & oblíquo & $600 \mathrm{~m}$ & cilíndrico-cônica & 500 & 21 \\
\hline 648 & $22^{\circ} 38^{\prime} 25,0^{\prime \prime}$ & $040^{\circ} 17^{\prime} 41,0^{\prime \prime}$ & $19 / 05 / 2002$ & oblíquo & $40 \mathrm{~m}$ & bongô & 330 & 2 \\
\hline 693 & $22^{\circ} 41^{\prime} 54,7^{\prime \prime}$ & $040^{\circ} 14^{\prime} 04,5^{\prime \prime}$ & $16 / 05 / 2002$ & oblíquo & $1.000 \mathrm{~m}$ & cilíndrico-cônica & 500 & 13 \\
\hline 17468 & $22^{\circ} 35^{\prime} 08^{\prime \prime}$ & $039^{\circ} 46^{\prime} 22,3^{\prime \prime}$ & $06 / 12 / 2002$ & vertical & $0-50 \mathrm{~m}$ & cilíndrico-cônica & 200 & 2 \\
\hline 20044 & $22^{\circ} 33^{\prime} 477^{\prime \prime}$ & $040^{\circ} 12^{\prime} 20,5^{\prime \prime}$ & $17 / 05 / 2002$ & oblíquo & $50 \mathrm{~m}$ & bongô & 500 & 4 \\
\hline 20045 & $22^{\circ} 38^{\prime} 29,0^{\prime \prime}$ & $040^{\circ} 17^{\prime} 40,0^{\prime \prime}$ & $18 / 05 / 2002$ & oblíquo & $800 \mathrm{~m}$ & cilíndrico-cônica & 500 & 2 \\
\hline 20048 & $22^{\circ} 33^{\prime} 477^{\prime \prime}$ & $040^{\circ} 12^{\prime} 20,5^{\prime \prime}$ & $17 / 05 / 2002$ & oblíquo & $50 \mathrm{~m}$ & bongô & 330 & 3 \\
\hline 20055 & $22^{\circ} 38^{\prime} 25,0^{\prime \prime}$ & $040^{\circ} 17^{\prime} 41,0^{\prime \prime}$ & $19 / 05 / 2002$ & oblíquo & $40 \mathrm{~m}$ & bongô & 500 & 1 \\
\hline 20059 & $22^{\circ} 36^{\prime} 54,9^{\prime \prime}$ & $040^{\circ} 09^{\prime} 19,4^{\prime \prime}$ & $16 / 05 / 2002$ & oblíquo & $50 \mathrm{~m}$ & bongô & 330 & 15 \\
\hline 20067 & $22^{\circ} 33^{\prime} 37,0^{\prime \prime}$ & $040^{\circ} 19^{\prime} 10,0^{\prime \prime}$ & $17 / 05 / 2002$ & oblíquo & $50 \mathrm{~m}$ & bongô & 500 & 15 \\
\hline 20070 & $22^{\circ} 34^{\prime} 05,0^{\prime \prime}$ & $040^{\circ} 19^{\prime} 40,0^{\prime \prime}$ & $17 / 05 / 2002$ & oblíquo & $600 \mathrm{~m}$ & cilíndrico-cônica & 500 & 13 \\
\hline
\end{tabular}

Referências: Menezes \& Figueiredo, 1985; Watson, 1996i; Westneat, 2002b; Jones et al., 2006b; Fahay, 2007. 


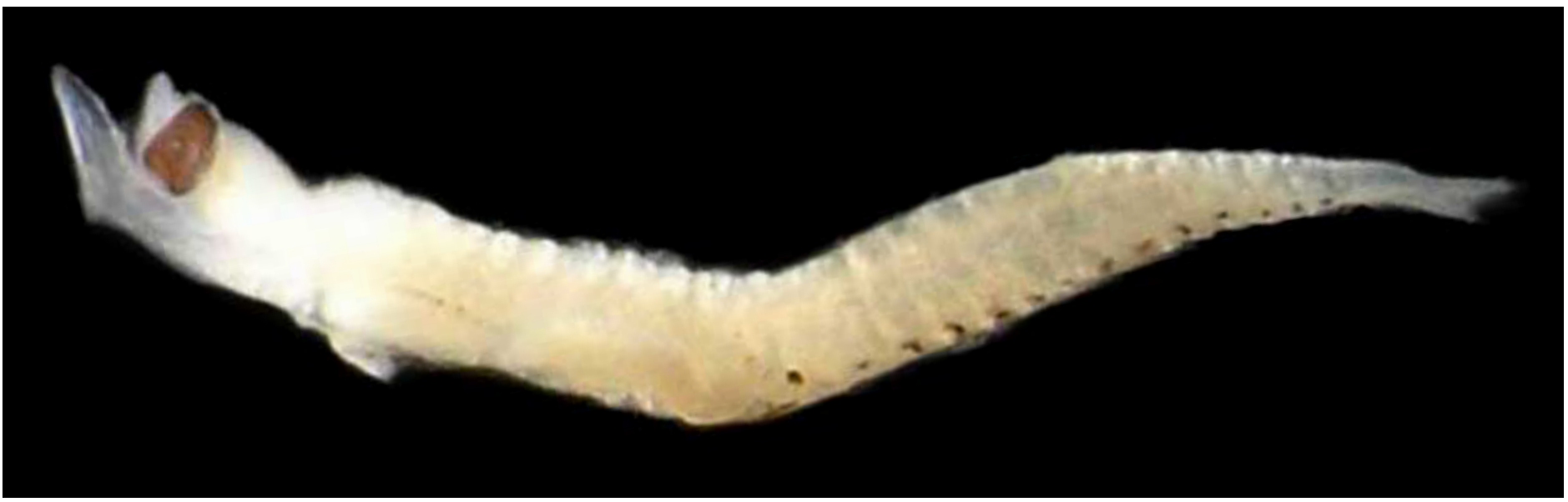

Figura 132 - A: Sparisoma sp. DZUFRJ 500; Pré-flexão; CP 3,0 mm.

\section{Sparisoma sp.}

A principal característica que permite a separação desse gênero é a presença de um grande melanóforo atrás da base da nadadeira peitoral, na região cardíaca, desde a pré-flexão até os últimos estágios de desenvolvimento. Possui melanóforos na região dorso-lateral do ânus e uma série ao longo da margem ventral da cauda. Número total de miômeros 25. No Brasil já foram registradas dez espécies de Sparisoma.

Tamanho: pré-flexão 2,3-3,5 mm; flexão 3,6-7,6 mm; pós-flexão 7,8$11,0 \mathrm{~mm}$.

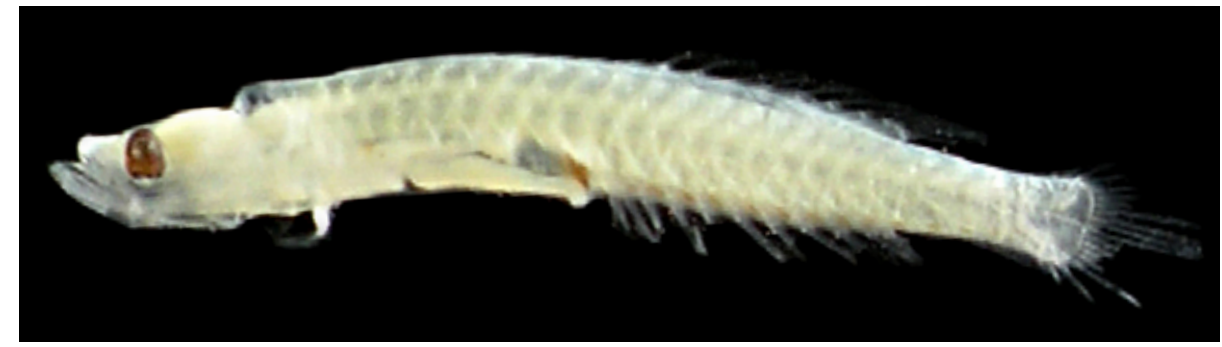

Figura 132 - B: DZUFRJ 1355; Flexão; CP 4,5 mm.

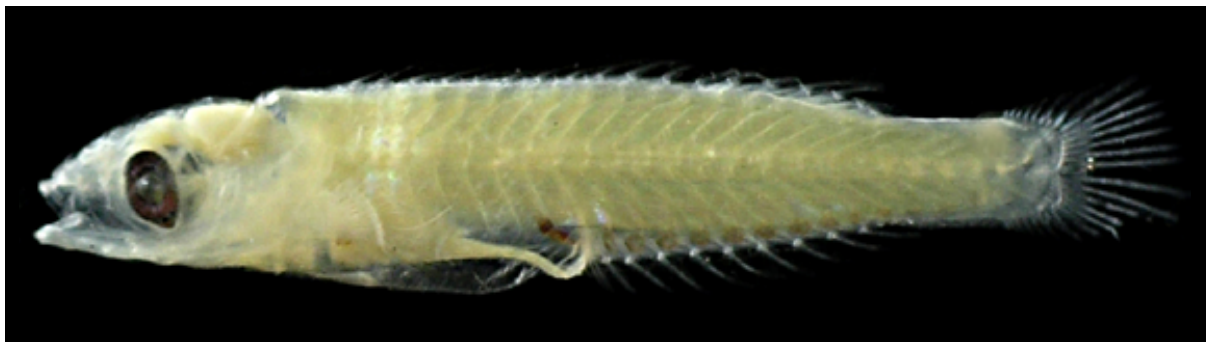

Figura 132 - C: DZUFRJ 1217; Pós-flexão; CP 8,0 mm.

Habitat: as espécies de Sparisoma são marinhas e demersais. Vivem em áreas de formações coralinas, associadas a algas, gramas marinhas e substratos rochosos.

\section{Georreferenciamento}

\begin{tabular}{|c|c|c|c|c|c|c|c|c|}
\hline DZUFR J & Latitude (S) & Longitude (W) & Data & $\begin{array}{c}\text { Tipo de } \\
\text { arrasto }\end{array}$ & $\begin{array}{c}\text { Profundidade } \\
\text { de coleta }\end{array}$ & Rede & $\begin{array}{c}\text { Malha } \\
\text { ( } \boldsymbol{\mu m} \text { ) }\end{array}$ & $\begin{array}{c}\text { No. de } \\
\text { inds. }\end{array}$ \\
\hline 485 & $22^{\circ} 33^{\prime} 37,0^{\prime \prime}$ & $040^{\circ} 19^{\prime} 10,0^{\prime \prime}$ & $17 / 05 / 2002$ & oblíquo & $50 \mathrm{~m}$ & bongô & 500 & 7 \\
\hline 500 & $22^{\circ} 38^{\prime} 25,0^{\prime \prime}$ & $040^{\circ} 17^{\prime} 41,0^{\prime \prime}$ & $19 / 05 / 2002$ & oblíquo & $40 \mathrm{~m}$ & bongô & 500 & 2 \\
\hline 554 & $22^{\circ} 32^{\prime} 03,0^{\prime \prime}$ & $040^{\circ} 17^{\prime} 21,0^{\prime \prime}$ & $19 / 05 / 2002$ & oblíquo & $30 \mathrm{~m}$ & bongô & 330 & 2 \\
\hline 561 & $22^{\circ} 32^{\prime} 03,0^{\prime \prime}$ & $040^{\circ} 17^{\prime} 21,0^{\prime \prime}$ & $19 / 05 / 2002$ & oblíquo & $30 \mathrm{~m}$ & bongô & 500 & 3 \\
\hline 578 & $22^{\circ} 33^{\prime} 37,0^{\prime \prime}$ & $040^{\circ} 19^{\prime} 10,0^{\prime \prime}$ & $17 / 05 / 2002$ & oblíquo & $50 \mathrm{~m}$ & bongô & 330 & 22 \\
\hline 585 & $22^{\circ} 33^{\prime} 45,8^{\prime \prime}$ & $040^{\circ} 13^{\prime} 22,9^{\prime \prime}$ & $17 / 05 / 2002$ & oblíquo & $800 \mathrm{~m}$ & cilíndrico-cônica & 500 & 8 \\
\hline 596 & $22^{\circ} 33^{\prime} 47,7^{\prime \prime}$ & $040^{\circ} 12^{\prime} 20,5^{\prime \prime}$ & $17 / 05 / 2002$ & oblíquo & $50 \mathrm{~m}$ & bongô & 330 & 15 \\
\hline 611 & $22^{\circ} 42^{\prime} 06,0^{\prime \prime}$ & $040^{\circ} 14^{\prime} 26,0^{\prime \prime}$ & $19 / 05 / 2002$ & oblíquo & $50 \mathrm{~m}$ & bongô & 330 & 12 \\
\hline 617 & $22^{\circ} 42^{\prime} 06,0^{\prime \prime}$ & $040^{\circ} 14^{\prime} 26,0^{\prime \prime}$ & $19 / 05 / 2002$ & oblíquo & $50 \mathrm{~m}$ & bongô & 500 & 13 \\
\hline 637 & $22^{\circ} 36^{\prime} 54,9^{\prime \prime}$ & $040^{\circ} 09^{\prime} 19,4^{\prime \prime}$ & $16 / 05 / 2002$ & oblíquo & $50 \mathrm{~m}$ & bongô & 500 & 20 \\
\hline
\end{tabular}




\begin{tabular}{|c|c|c|c|c|c|c|c|c|}
\hline DZUFRJ & Latitude (S) & Longitude (W) & Data & $\begin{array}{l}\text { Tipo de } \\
\text { arrasto }\end{array}$ & $\begin{array}{c}\text { Profundidade } \\
\text { de coleta }\end{array}$ & Rede & $\begin{array}{l}\text { Malha } \\
(\mu \mathrm{m})\end{array}$ & $\begin{array}{l}N^{\circ} \text {. de } \\
\text { inds. }\end{array}$ \\
\hline 669 & $22^{\circ} 33^{\prime} 47,7^{\prime \prime}$ & $040^{\circ} 12^{\prime} 20,5^{\prime \prime}$ & $17 / 05 / 2002$ & oblíquo & $50 \mathrm{~m}$ & bongô & 500 & 5 \\
\hline 1168 & $22^{\circ} 02^{\prime} 30,3^{\prime \prime}$ & $039^{\circ} 50 ' 41,3^{\prime \prime}$ & $10 / 05 / 2002$ & oblíquo & $1.000 \mathrm{~m}$ & cilíndrico-cônica & 500 & 1 \\
\hline 1180 & $22^{\circ} 07^{\prime} 29,0^{\prime \prime}$ & $039^{\circ} 06^{\prime} 23,5^{\prime \prime}$ & $10 / 05 / 2002$ & oblíquo & $1.000 \mathrm{~m}$ & cilíndrico-cônica & 500 & 78 \\
\hline 1195 & $22^{\circ} 03^{\prime} 03,3^{\prime \prime}$ & $039^{\circ} 50^{\prime} 39,0^{\prime \prime}$ & $10 / 05 / 2002$ & oblíquo & até a termoclina & bongô & 500 & 1 \\
\hline 1202 & $22^{\circ} 06^{\prime} 52,3^{\prime \prime}$ & $039^{\circ} 48^{\prime} 46,2^{\prime \prime}$ & $11 / 05 / 2002$ & oblíquo & $1.000 \mathrm{~m}$ & cilíndrico-cônica & 500 & 5 \\
\hline 1217 & $22^{\circ} 02^{\prime} 30,0^{\prime \prime}$ & $039^{\circ} 49^{\prime} 41,2^{\prime \prime}$ & $12 / 05 / 2002$ & oblíquo & $1.000 \mathrm{~m}$ & cilíndrico-cônica & 500 & 6 \\
\hline 1247 & $22^{\circ} 08^{\prime} 17,5^{\prime \prime}$ & $039^{\circ} 46^{\prime} 28,5^{\prime \prime}$ & $11 / 05 / 2002$ & oblíquo & $1.000 \mathrm{~m}$ & cilíndrico-cônica & 500 & 22 \\
\hline 1274 & $22^{\circ} 06^{\prime} 37,8^{\prime \prime}$ & $039^{\circ} 49^{\prime} 44,8^{\prime \prime}$ & $10 / 05 / 2002$ & oblíquo & té a termoclina & bongô & 500 & 41 \\
\hline 1294 & $22^{\circ} 02^{\prime} 30,0^{\prime \prime}$ & $039^{\circ} 49^{\prime} 41,2^{\prime \prime}$ & $12 / 05 / 2002$ & oblíquo & até a termoclina & bongô & 500 & 17 \\
\hline 1305 & $22^{\circ} 08^{\prime} 52,5^{\prime \prime}$ & $039^{\circ} 46^{\prime} 27,9^{\prime \prime}$ & $12 / 05 / 2002$ & oblíquo & até a termoclina & bongô & 500 & 1 \\
\hline 1313 & $22^{\circ} 08^{\prime} 14,9^{\prime \prime}$ & $039^{\circ} 46^{\prime} 34,6^{\prime \prime}$ & $11 / 05 / 2002$ & oblíquo & até a termoclina & bongô & 500 & 14 \\
\hline 1322 & $22^{\circ} 03^{\prime} 03,3^{\prime \prime}$ & $039^{\circ} 50^{\prime} 39,0^{\prime \prime}$ & $10 / 05 / 2002$ & oblíquo & até a termoclina & bongô & 330 & 2 \\
\hline 1332 & $22^{\circ} 06^{\prime} 37,8^{\prime \prime}$ & $039^{\circ} 49^{\prime} 44,8^{\prime \prime}$ & $10 / 05 / 2002$ & oblíquo & até a termoclina & bongô & 330 & 26 \\
\hline 1344 & $22^{\circ} 06^{\prime} 52,3^{\prime \prime}$ & $039^{\circ} 48^{\prime} 46,2^{\prime \prime}$ & $11 / 05 / 2002$ & oblíquo & até a termoclina & bongô & 330 & 2 \\
\hline 1355 & $22^{\circ} 02^{\prime} 30,0^{\prime \prime}$ & $039^{\circ} 49^{\prime} 41,2^{\prime \prime}$ & $12 / 05 / 2002$ & oblíquo & até a termoclina & bongô & 330 & 19 \\
\hline 7608 & $21^{\circ} 57^{\prime} 10,5^{\prime \prime}$ & $43 ' 33,3^{\prime \prime}$ & 09/10/2001 & oblíquo & $1.000 \mathrm{~m}$ & cilíndrico-cônica & 500 & 2 \\
\hline 7611 & $21^{\circ} 58^{\prime} 31,0^{\prime \prime}$ & $039^{\circ} 50^{\prime} 29,7^{\prime \prime}$ & $10 / 10 / 2001$ & oblíquo & $1.000 \mathrm{~m}$ & cilíndrico-cônica & 500 & 4 \\
\hline 7613 & $21^{\circ} 54^{\prime} 36,5^{\prime \prime}$ & $039^{\circ} 45^{\prime} 20,0^{\prime \prime}$ & $10 / 10 / 2001$ & oblíquo & 1.0 & cilíndrico-cônica & 500 & 4 \\
\hline 7614 & $21^{\circ} 57^{\prime} 10,5^{\prime \prime}$ & $039^{\circ} 43^{\prime} 33,3^{\prime \prime}$ & 09/10/2001 & oblíquo & 1.0 & cilíndrico-cônica & 500 & 2 \\
\hline 7615 & $21^{\circ} 54^{\prime} 36,5^{\prime \prime}$ & $039^{\circ} 45^{\prime} 20,0^{\prime \prime}$ & $10 / 10 / 2001$ & oblíquo & $1.000 \mathrm{~m}$ & cilíndrico-cônica & 500 & 12 \\
\hline 7617 & $21^{\circ} 58^{\prime} 31,0^{\prime \prime}$ & $039^{\circ} 50^{\prime} 29,7^{\prime \prime}$ & $10 / 11 / 2001$ & oblíquo & 1.00 & cilíndrico-cônica & 500 & 3 \\
\hline 7618 & $21^{\circ} 54^{\prime} 36,5^{\prime \prime}$ & $039^{\circ} 45^{\prime} 20,0^{\prime \prime}$ & 09/10/2001 & oblíquo & $1.000 \mathrm{~m}$ & cilíndrico-cônica & 500 & 12 \\
\hline 17467 & $22^{\circ} 07^{\prime} 58,8^{\prime \prime}$ & $039^{\circ} 49^{\prime} 08,9^{\prime \prime}$ & $01 / 12 / 2002$ & vertical & $0-50 m$ & cilíndrico-cônica & 500 & 1 \\
\hline 17478 & $22^{\circ} 02,27^{\prime}$ & $039^{\circ} 43,49^{\prime}$ & $18 / 06 / 2003$ & vertical & $0-90 m$ & cilíndrico-cônica & 500 & 3 \\
\hline 17479 & 9,68 & $40^{\circ} 0$ & $13 / 06 / 2003$ & vertical & $0-60 m$ & cilíndrico-cônica & 00 & 2 \\
\hline 17480 & $22^{\circ} 35,12^{\prime}$ & $9^{\circ} 46,24^{\prime}$ & $15 / 06 / 2003$ & vertical & $0-80 m$ & cilíndrico-cônica & 500 & 1 \\
\hline 17481 & $22^{\circ} 43,56^{\prime}$ & $039^{\circ} 53,25^{\prime}$ & $14 / 06 / 2003$ & vertical & $1.000-2.000 \mathrm{~m}$ & cilíndrico-cônica & 500 & 2 \\
\hline 17488 & $22^{\circ} 3$ & & $07 / 11 /$ & oblíquo & $1.000 \mathrm{~m}$ & cilíndrico-cônica & 00 & 17 \\
\hline 17489 & $22^{\circ} 32^{\prime} 50,0^{\prime \prime}$ & $040^{\circ} 04^{\prime} 09,9^{\prime \prime}$ & $06 / 11 / 2001$ & oblíquo & $0 \mathrm{~m}$ & cilíndrico-cônica & 500 & 1 \\
\hline 17490 & $22^{\circ} 31^{\prime} 40,9^{\prime \prime}$ & $040^{\circ} 02^{\prime} 39,6^{\prime \prime}$ & $07 / 11 / 2001$ & oblíquo & $1.000 \mathrm{~m}$ & cilíndrico-cônica & 500 & 10 \\
\hline 17491 & $22^{\circ} 31^{\prime} 4$ & 040 & $07 / 11 / 2$ & oblíquo & & cilíndrico-cônica & 00 & 7 \\
\hline 17492 & $22^{\circ} 32^{\prime} 49,0^{\prime \prime}$ & $040^{\circ} 04^{\prime} 20,9^{\prime \prime}$ & $07 / 11 / 2001$ & oblíquo & $1.000 \mathrm{~m}$ & cilíndrico-cônica & 500 & 15 \\
\hline 17493 & $22^{\circ} 32^{\prime} 50,0^{\prime \prime}$ & $040^{\circ} 04^{\prime} 09,9^{\prime \prime}$ & $06 / 11 / 2001$ & oblíquo & $1.000 \mathrm{~m}$ & cilíndrico-cônica & 500 & 1 \\
\hline 17494 & $22^{\circ} 31^{\prime} 40,9^{\prime \prime}$ & $040^{\circ} 02^{\prime} 39,6^{\prime \prime}$ & $07 / 11 / 2001$ & oblíquo & $1.000 \mathrm{~m}$ & cilíndrico-cônica & 500 & 11 \\
\hline 17496 & $22^{\circ} 31^{\prime} 58,9^{\prime \prime}$ & $040^{\circ} 02^{\prime} 53,4^{\prime \prime}$ & $07 / 11 / 2001$ & oblíquo & $1.000 \mathrm{~m}$ & cilíndrico-cônica & 500 & 1 \\
\hline 17497 & $22^{\circ} 32^{\prime} 49,0^{\prime \prime}$ & $040^{\circ} 04^{\prime} 20,9^{\prime \prime}$ & $07 / 11 / 2001$ & oblíquo & $1.000 \mathrm{~m}$ & cilíndrico-cônica & 500 & 20 \\
\hline 20041 & 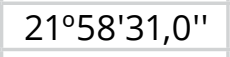 & $039^{\circ} 50^{\prime} 29,7^{\prime \prime}$ & $10 / 10 / 2001$ & oblíquo & $1.000 \mathrm{~m}$ & cilíndrico-cônica & 500 & 3 \\
\hline 20049 & $22^{\circ} 34^{\prime} 05,0^{\prime \prime}$ & $040^{\circ} 19^{\prime} 40,0^{\prime \prime}$ & $17 / 05 / 2002$ & oblíquo & $600 \mathrm{~m}$ & cilíndrico-cônica & 500 & 6 \\
\hline 20051 & $22^{\circ} 41^{\prime} 54,7^{\prime \prime}$ & $040^{\circ} 14^{\prime} 04,5^{\prime \prime}$ & $16 / 05 / 2002$ & oblíquo & $1.000 \mathrm{~m}$ & cilíndrico-cônica & 500 & 2 \\
\hline 20060 & $22^{\circ} 38^{\prime} 25,0^{\prime \prime}$ & $040^{\circ} 17^{\prime} 41,0^{\prime \prime}$ & 19/05/2002 & oblíquo & $40 \mathrm{~m}$ & bongô & 330 & 2 \\
\hline 20072 & $22^{\circ} 37^{\prime} 35,5^{\prime \prime}$ & $040^{\circ} 09^{\prime} 32,8^{\prime \prime}$ & $16 / 05 / 2002$ & oblíquo & $1.000 \mathrm{~m}$ & cilíndrico-cônica & 500 & 18 \\
\hline 20073 & $22^{\circ} 36^{\prime} 54,9^{\prime \prime}$ & $040^{\circ} 09^{\prime} 19,4^{\prime \prime}$ & $16 / 05 / 2002$ & oblíquo & $50 \mathrm{~m}$ & bongô & 330 & 55 \\
\hline 20074 & $21^{\circ} 53^{\prime} 10,4^{\prime \prime}$ & $039^{\circ} 45^{\prime} 49,9^{\prime \prime}$ & $10 / 10 / 2001$ & oblíquo & $1.000 \mathrm{~m}$ & cilíndrico-cônica & 500 & 2 \\
\hline
\end{tabular}

Referências: Menezes \& Figueiredo, 1985; Watson, 1996i; Westneat, 2002b; Jones et al., 2006b; Fahay, 2007. 


\section{Família Chiasmodontidae}

A família Chiasmodontidae é tipicamente mesopelágica e batipelágica e algumas espécies podem ser encontradas em até $2.740 \mathrm{~m}$ de profundidade. A maioria das espécies vive em áreas tropicais e temperadas, nos oceanos Atlântico e Pacífico. Compreende quatro gêneros com aproximadamente 15 espécies.

Apresenta o corpo estreito e cabeça proporcionalmente pequena. Pode ser separada dos demais Perciformes pelo pré-maxilar e mandíbula longas e finas, intestino dilatado, nadadeiras dorsais separadas, 33 a 48 vértebras. Os representantes dos gêneros Chiasmodon e Pseudoscopelus possuem muitos espinhos espalhados pelo corpo, estando ausentes no gênero Kali. Nesse gênero as nadadeiras peitoral e ventral são extremamente alongadas, a cabeça é achatada e os olhos ficam localizados próximos ao final da mandíbula.

No Brasil já foram identificadas as espécies Chiasmodon niger Johnson, 1864; Kali normani (Parr, 1931); Pseudoscopelus altipinnis Parr, 1933 e Pseudoscopelus scutatus Krefft, 1971. Nesse estudo é contemplada a espécie Chiasmodon niger. 


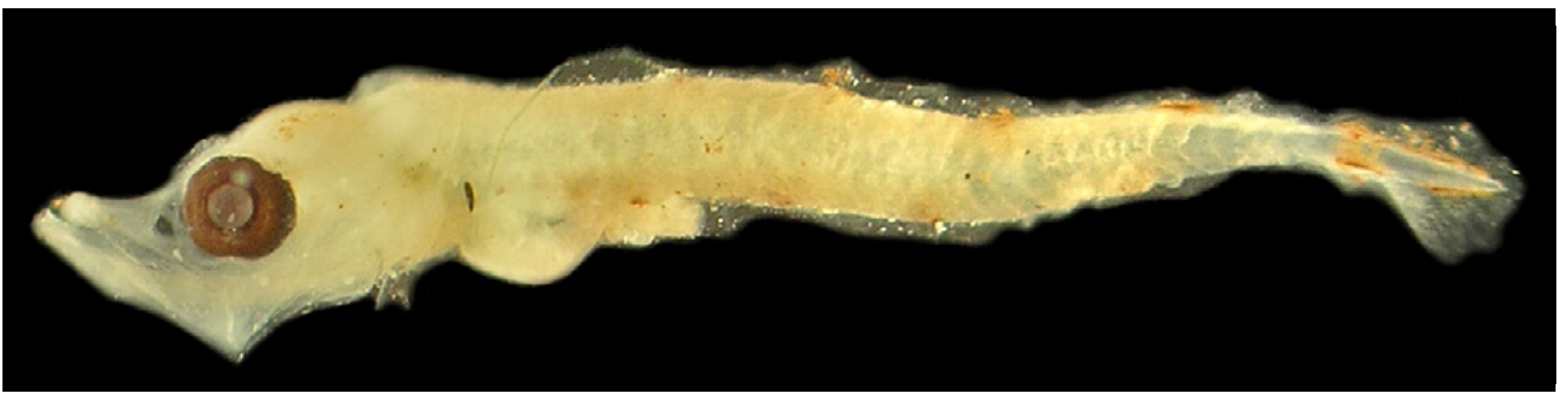

Figura 133 - A: Chiasmodon niger. DZUFRJ 12183; Pré-flexão; CP 4,2 mm.

\section{Chiasmodon}

\section{niger Johnson, 1864}

As larvas possuem o corpo alongado (42 a 44 miômeros), com cabeça pequena e focinho pontudo.

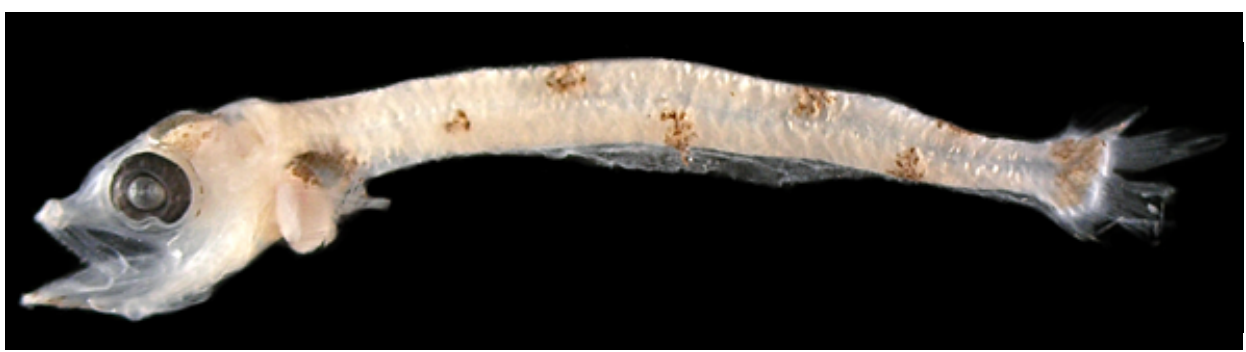

Figura 133 - B: DZUFRJ 22506; Flexão; CP 8,4 mm.

Os olhos são ovais nas larvas em pré-flexão e arredondados durante a flexão. Presença de poucos espinhos na cabeça, no entanto o corpo é coberto com espículas, que começam a se formar a partir de duas fileiras nas superfícies dorso e ventro-laterais, para depois cobrir todo o corpo. Em pré-flexão, as larvas apresentam três manchas de pigmentos apenas na margem ventral do corpo. Com o crescimento, duas manchas de pigmentos dorsais alternam com as ventrais. Presença de cromatóforos próximos à extremidade da notocorda e aumento da quantidade de pigmentos na cabeça. As larvas em flexão seguem o mesmo padrão dos estágios iniciais, porém com pigmentação mais intensa.

Tamanho: pré-flexão 3,5-4,8 mm; flexão 7,0-8,4 mm.

Habitat: espécie marinha, mesopelágica e batipelágica, ocorre em águas tropicais e subtropicais em profundidades maiores que $750 \mathrm{~m}$.

\section{Georreferenciamento}

\begin{tabular}{|c|c|c|c|c|c|c|c|c|}
\hline DZUFR & Latitude (S) & Longitude (W) & Data & $\begin{array}{c}\text { Tipo de } \\
\text { arrasto }\end{array}$ & $\begin{array}{c}\text { Profundidade } \\
\text { de coleta }\end{array}$ & Rede & $\begin{array}{c}\text { Malha } \\
(\boldsymbol{\mu m})\end{array}$ & $\begin{array}{c}\mathbf{N}^{\circ} \text {. de } \\
\text { inds. }\end{array}$ \\
\hline 1204 & $22^{\circ} 06^{\prime} 52,3^{\prime \prime}$ & $039^{\circ} 48^{\prime} 46,2^{\prime \prime}$ & $11 / 05 / 2002$ & oblíquo & $1.000 \mathrm{~m}$ & cilíndrico-cônica & 500 & 2 \\
\hline 1242 & $22^{\circ} 03^{\prime} 21,7^{\prime \prime}$ & $039^{\circ} 45^{\prime} 11,9^{\prime \prime}$ & $12 / 05 / 2002$ & oblíquo & $1.000 \mathrm{~m}$ & cilíndrico-cônica & 500 & 1 \\
\hline 1389 & $22^{\circ} 08^{\prime} 149^{\prime \prime}$ & $039^{\circ} 46^{\prime} 34,6^{\prime \prime}$ & $11 / 05 / 2002$ & oblíquo & até a termoclina & bongô & 330 & 1 \\
\hline 22506 & $22^{\circ} 32^{\prime} 50,0^{\prime \prime}$ & $040^{\circ} 04^{\prime} 09^{\prime \prime}$ & $06 / 11 / 2001$ & oblíquo & $1.000 \mathrm{~m}$ & cilíndrico-cônica & 500 & 2 \\
\hline 22507 & $21^{\circ} 53^{\prime} 10,4^{\prime \prime}$ & $039^{\circ} 45^{\prime} 49,9^{\prime \prime}$ & $10 / 10 / 2001$ & oblíquo & $1.000 \mathrm{~m}$ & cilíndrico-cônica & 500 & 1 \\
\hline
\end{tabular}

Referências: Watson \& Sandknop, 1996; McEachran; 2002; Hardy, 2006c; Fahay, 2007. 


\section{Família Callionymidae}

A família Callionymidae é marinha, com duas espécies que entram em rios, ocorrendo em todos os mares temperados. São pequenos e demersais, vivendo em regiões tropicais e subtropicais, até $650 \mathrm{~m}$ de profundidade. As espécies dessa família ocupam os mais diferentes tipos de habitat. Compreende dez gêneros com aproximadamente 182 espécies.

As larvas de Callionymidae são diferenciadas das demais famílias devido ao padrão característico de pigmentação lateral, a presença de espinhos no pré-opérculo, a morfologia do corpo, ao baixo número de miômeros e por possuir a extremidade da notocorda alongada. As larvas são robustas anteriormente, mas a região posterior do corpo é caracterizada por uma notocorda longa e fina. A pigmentação do corpo é constituída por uma série de melanóforos que se desenvolve durante a pré-flexão e permanece por todo período larval.

No Brasil já foram identificadas três espécies nas fases de larva e adulto: Foetorepus agassizii (Goode \& Bean, 1888); Foetorepus dagmarae (Fricke, 1985) e Callionymus bairdi Jordan, 1888. Nesse estudo é contemplada a espécie Callionymus bairdi. 


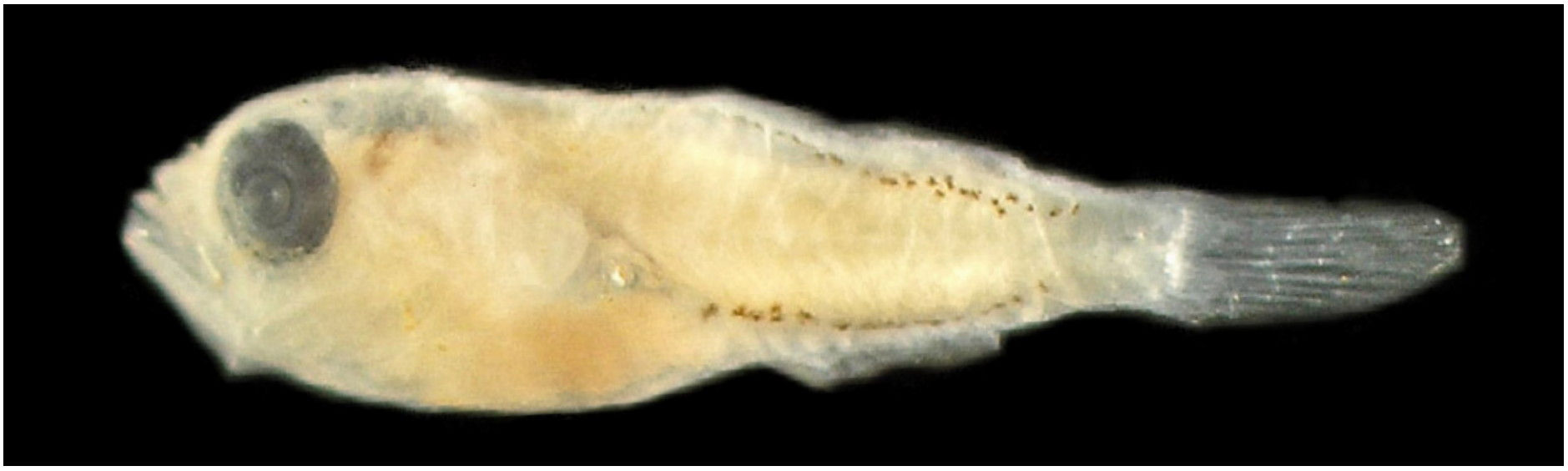

Figura 134 - A: Callionymus bairdi. DZUFRJ 33540; Flexão; CP 3,3 mm.

\section{Callionymus bairdi Jordan, 1888}

As larvas dessa espécie possuem a extremidade da notocorda longa e entre 21 e 22 miômeros. A flexão ocorre em larvas com menos de 2,0 mm de comprimento. Nesse estágio, caracterizam-se pela presença de um semicírculo pigmentado na região mediana e posterior

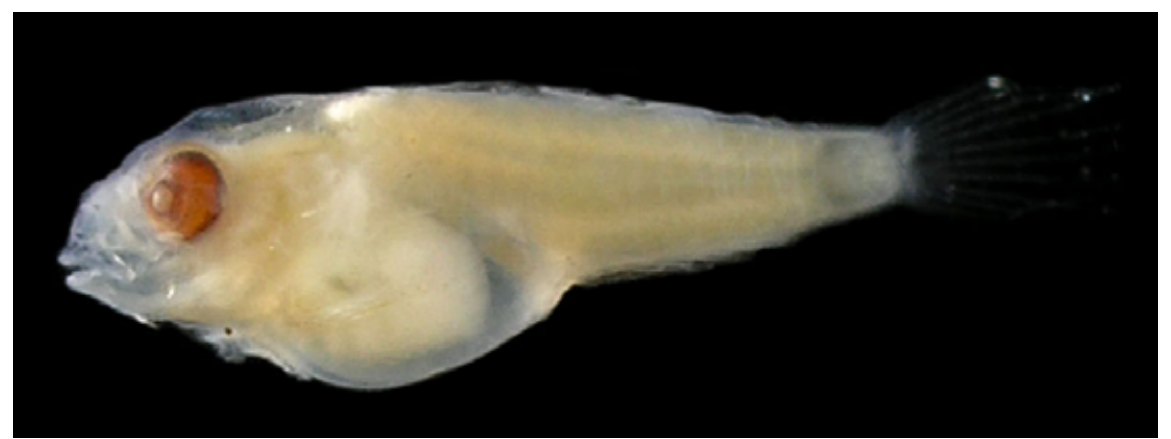

Figura 134 - B: DZUFRJ 20063; Pós-flexão; CP 6,0 mm.

da cabeça. Tem pigmentos ventrais na porção anterior do intestino e na linha dorsal, formando duas fileiras distintas. Esse padrão de pigmentação espalha-se pelo corpo com o desenvolvimento da larva. Há pigmentos também entre os raios das nadadeiras pélvicas. Nadadeira dorsal: IV, 9 (8-10); nadadeira anal: 8 (6-9); nadadeira peitoral: 19-20.

Tamanho: flexão 3,3-4,5 mm; pós-flexão 6,0 mm.

Habitat: espécie marinha, demersal, ocorre em águas tropicais até $91 \mathrm{~m}$ de profundidade.

Nome vulgar: Dragãozinho.

\section{Georreferenciamento}

\begin{tabular}{|c|c|c|c|c|c|c|c|c|}
\hline DZUFRJ & Latitude (S) & Longitude (W) & Data & $\begin{array}{c}\text { Tipo de } \\
\text { arrasto }\end{array}$ & $\begin{array}{c}\text { Profundidade } \\
\text { de coleta }\end{array}$ & Rede & $\begin{array}{c}\text { Malha } \\
\text { ( } \begin{array}{c}\boldsymbol{N} \text { m }) \\
\text { inds. de }\end{array}\end{array}$ \\
\hline 1172 & $22^{\circ} 02^{\prime} 30,3^{\prime \prime}$ & $039^{\circ} 50^{\prime} 41,3^{\prime \prime}$ & $10 / 05 / 2002$ & oblíquo & $1.000 \mathrm{~m}$ & cilíndrico-cônica & 500 & 1 \\
\hline 7487 & $21^{\circ} 58^{\prime} 31,0^{\prime \prime}$ & $039^{\circ} 50^{\prime} 29,7^{\prime \prime}$ & $11 / 10 / 2001$ & oblíquo & $1.000 \mathrm{~m}$ & cilíndrico-cônica & 500 & 1 \\
\hline 7489 & $21^{\circ} 54^{\prime} 36,5^{\prime \prime}$ & $039^{\circ} 45^{\prime} 20,0^{\prime \prime}$ & $09 / 10 / 2001$ & oblíquo & $1.000 \mathrm{~m}$ & cilíndrico-cônica & 500 & 1 \\
\hline 20063 & $22^{\circ} 31^{\prime} 58,9^{\prime \prime}$ & $040^{\circ} 02^{\prime} 53,4^{\prime \prime}$ & $07 / 11 / 2001$ & oblíquo & $1.000 \mathrm{~m}$ & cilíndrico-cônica & 500 & 1 \\
\hline
\end{tabular}

Referências: Menezes \& Figueiredo, 1985; Watson, 1996j; Fricke; 2002; Powell \& Greene, 2006b; Fahay, 2007. 


\section{Família Gobiidae}

A família Gobiidae ocorre em ambientes marinhos, salobros e ocasionalmente de água doce, na maioria das áreas tropicais e subtropicais. Grande parte das espécies é marinha vivendo associada a formações coralinas ou ainda podem estar presentes em regiões costeiras, associados à baixa salinidade, próximo ao fundo. Compreende aproximadamente 210 gêneros com no mínimo 1.950 espécies. É a família marinha com o maior número de espécies e a sua sistemática está sendo revista.

As características usadas na separação das larvas de Gobiidae são: forma do corpo, tamanho dos olhos, número de raios das nadadeiras e padrão de pigmentação. Na maioria das espécies as nadadeiras dorsais são separadas e as bases das dorsais e da anal são curtas. A cabeça e os olhos são proporcionalmente de tamanho moderado, com pigmentos na área dos olhos. O corpo é alongado, quase sem diferenciação de espessura entre a cabeça e a cauda. Possuem um longo pedúnculo caudal. O intestino é reto ou um pouco curvado para baixo da vesícula gasosa e se estende até aproximadamente metade do corpo. Possui vesícula gasosa grande que se torna proeminente nas larvas maiores que $10 \mathrm{~mm}$ de comprimento, com pigmentação típica nas superfícies dorsal e posterior. Ausência de espinhos na cabeça.

Presença de um ou muitos melanóforos, simples ou pareados, uniformemente espaçados, na linha ventral da cauda. Pigmentos são frequentemente encontrados na região ventral do intestino e na base do istmo e da nadadeira pélvica.

No Brasil já foram identificadas 40 espécies nas fases de larva e adulto. Nesse estudo são contempladas as espécies Bathygobius soporator, Ctenogobius sp., Gnatholepis thompsoni, Gobionellus sp. 1, Gobionellus sp. 2 e o morfotipo Gobiidae sp. 1. 


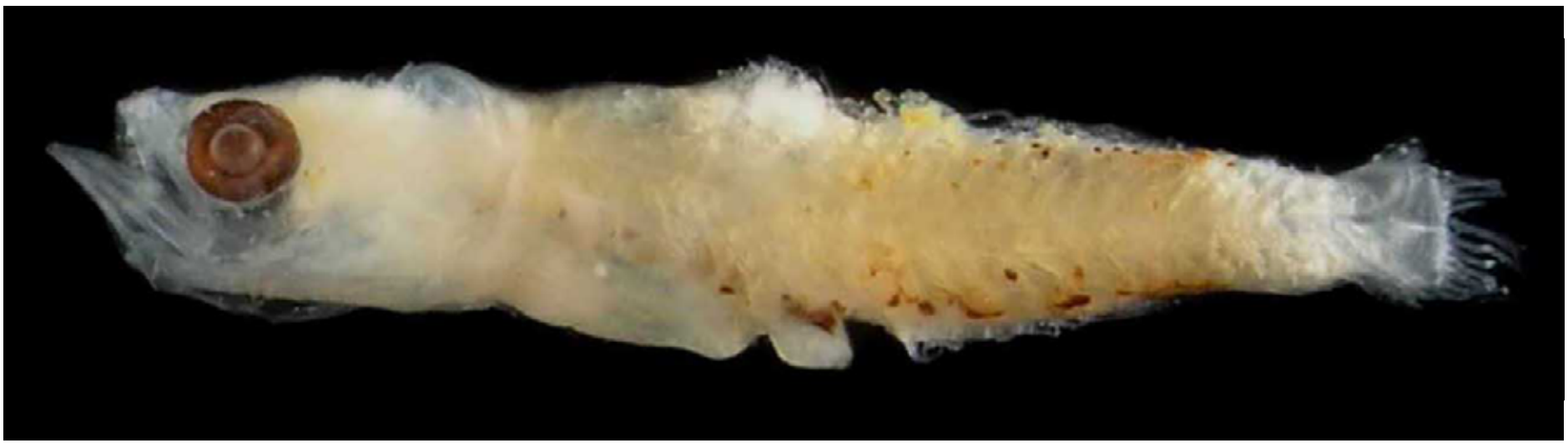

Figura 135: Bathygobius soporator. DZUFRJ 22243; Flexão; CP 4,0 mm.

\section{Bathygobius soporator (Valenciennes, 1837)}

As larvas dessa espécie são caracterizadas por serem muito pigmentadas e por terem o corpo mais alto que os demais gobiídeos. Nadadeira dorsal: VI, 10-11. Nadadeira anal: 8-9. Possui pigmentos internos na parte dorsal da cavidade abdominal. Tem densos melanóforos ao longo da linha ventral, formando uma fileira simples; e da linha dorsal, a partir da base da segunda nadadeira. Presença de melanóforos ao longo da maxila inferior e próximo aos olhos; melanóforos alongados na linha ventral do istmo, anteriormente ao grande melanóforo estrelado na base da nadadeira pélvica. Fileira de três manchas na linha ventral do abdome, atrás da nadadeira pélvica. Ausência de pigmentos na primeira nadadeira dorsal, na peitoral e na pélvica. Presença de pigmentos anteriormente a segunda nadadeira dorsal e melanóforos na base ventral da nadadeira caudal. Número total de miômeros: 27.

Tamanho: flexão 4,0 mm.

Habitat: espécie marinha, demersal, que pode habitar água doce e salobra. Ocorre em águas tropicais costeiras até $16 \mathrm{~m}$ de profundidade.

Nome vulgar: Amoré de buzo.

Georreferenciamento

\begin{tabular}{|c|c|c|c|c|c|c|c|c|}
\hline DZUFR & Latitude (S) & Longitude (W) & Data & Tipo de arrasto & $\begin{array}{c}\text { Profundidade } \\
\text { de coleta }\end{array}$ & Rede & $\begin{array}{c}\text { Malha } \\
\text { ( } \boldsymbol{\mu m} \text { ) }\end{array}$ & $\begin{array}{c}\text { No. de } \\
\text { inds. }\end{array}$ \\
\hline 22243 & $22^{\circ} 42^{\prime} 06,0^{\prime \prime}$ & $040^{\circ} 14^{\prime} 26,0^{\prime \prime}$ & $19 / 05 / 2002$ & oblíquo & $50 \mathrm{~m}$ & bongô & 500 & 1 \\
\hline
\end{tabular}

Referências: Figueiredo \& Menezes, 2000; Watson, 1996k; Baldwin \& Smith; 2003; Yeung \& Ruple, 2006; Fahay, 2007. 


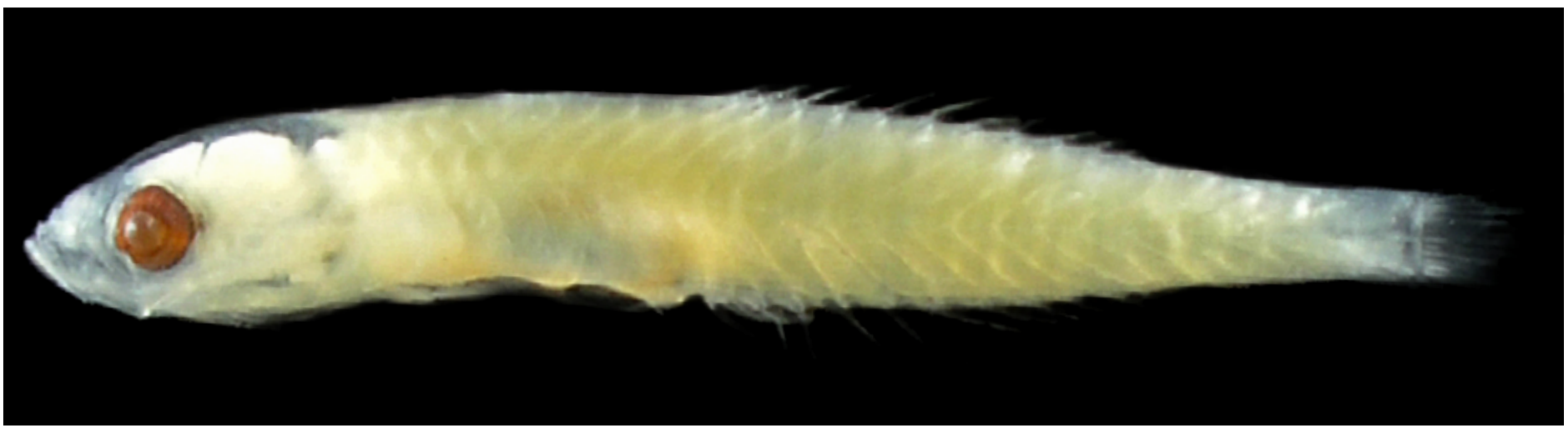

Figura 136 - A: Ctenogobius sp. DZUFRJ 5463; Flexão; CP 8,0 mm.

\section{Ctenogobius sp.}

Os representantes desse gênero possuem o corpo alongado (26 miômeros) e a cabeça proporcionalmente arredondada. São caracteri-

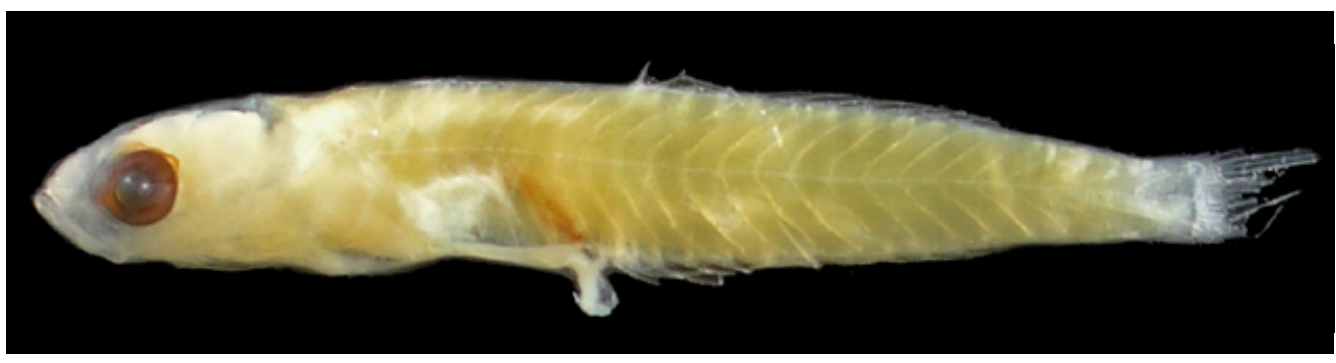

Figura 137 - B: DZUFRJ 5463; Pós-flexão; CP 11,0 mm. zados pela presença de pigmentos na região dorsal e posterior da vesícula gasosa. As nadadeiras dorsais são separadas: VI, 11-12. Nadadeira anal: I, 11.

Tamanho: flexão 4,8-8,0 mm; pós-flexão 8,5-11,0 mm.

Habitat: as espécies de Ctenogobius são marinhas, demersais, ocorrem em águas costeiras e estuarinas. No Brasil já foram registradas seis espécies de Ctenogobius.

\section{Georreferenciamento}

\begin{tabular}{|c|c|c|c|c|c|c|c|c|}
\hline DZUFRJ & Latitude (S) & Longitude (W) & Data & $\begin{array}{l}\text { Tipo de } \\
\text { arrasto }\end{array}$ & $\begin{array}{l}\text { Profundidade } \\
\text { de coleta }\end{array}$ & Rede & $\begin{array}{l}\text { Malha } \\
(\mu \mathrm{m})\end{array}$ & $\begin{array}{l}N^{\circ} \text {. de } \\
\text { inds. }\end{array}$ \\
\hline 1191 & $22^{\circ} 07^{\prime} 29,0^{\prime \prime}$ & $039^{\circ} 06^{\prime} 23,5^{\prime \prime}$ & $10 / 05 / 2002$ & oblíquo & $1.000 \mathrm{~m}$ & cilíndrico-cônica & 500 & 1 \\
\hline 1201 & $22^{\circ} 06^{\prime} 52,3^{\prime \prime}$ & $039^{\circ} 48^{\prime} 46,2^{\prime \prime}$ & $11 / 05 / 2002$ & oblíquo & $1.000 \mathrm{~m}$ & cilíndrico-cônica & 500 & 3 \\
\hline 1250 & $22^{\circ} 08^{\prime} 17,5^{\prime \prime}$ & $039^{\circ} 46^{\prime} 28,5^{\prime \prime}$ & $11 / 05 / 2002$ & oblíquo & $1.000 \mathrm{~m}$ & cilíndrico-cônica & 500 & 1 \\
\hline 1369 & $22^{\circ} 08^{\prime} 52,5^{\prime \prime}$ & $039^{\circ} 46^{\prime} 27,9^{\prime \prime}$ & $12 / 05 / 2002$ & oblíquo & até a termoclina & bongô & 330 & 1 \\
\hline 5463 & $22^{\circ} 32^{\prime} 49,0^{\prime \prime}$ & $040^{\circ} 04^{\prime} 20,9^{\prime \prime}$ & $07 / 11 / 2001$ & oblíquo & $1.000 \mathrm{~m}$ & cilíndrico-cônica & 500 & 5 \\
\hline 5464 & $22^{\circ} 31^{\prime} 40,9^{\prime \prime}$ & $040^{\circ} 02^{\prime} 39,6^{\prime \prime}$ & $07 / 11 / 2001$ & oblíquo & $1.000 \mathrm{~m}$ & cilíndrico-cônica & 500 & 1 \\
\hline 5467 & $22^{\circ} 31^{\prime} 58,9^{\prime \prime}$ & $040^{\circ} 02^{\prime} 53,4^{\prime \prime}$ & 07/11/2001 & oblíquo & $1.000 \mathrm{~m}$ & cilíndrico-cônica & 500 & 1 \\
\hline 5469 & $22^{\circ} 32^{\prime} 49,0^{\prime \prime}$ & $040^{\circ} 04^{\prime} 20,9^{\prime \prime}$ & $07 / 11 / 2001$ & oblíquo & $1.000 \mathrm{~m}$ & cilíndrico-cônica & 500 & 3 \\
\hline 5470 & $22^{\circ} 32^{\prime} 50,0^{\prime \prime}$ & $040^{\circ} 04^{\prime} 09,9^{\prime \prime}$ & $06 / 11 / 2001$ & oblíquo & $1.000 \mathrm{~m}$ & cilíndrico-cônica & 500 & 5 \\
\hline 7415 & $21^{\circ} 57^{\prime} 10,5^{\prime \prime}$ & $039^{\circ} 43^{\prime} 33,3^{\prime \prime}$ & 09/10/2001 & oblíquo & $1.000 \mathrm{~m}$ & cilíndrico-cônica & 500 & 1 \\
\hline 7418 & $21^{\circ} 57^{\prime} 10,5^{\prime \prime}$ & $039^{\circ} 43^{\prime} 33,3^{\prime \prime}$ & 09/10/2001 & oblíquo & $1.000 \mathrm{~m}$ & cilíndrico-cônica & 500 & 1 \\
\hline
\end{tabular}

Referências: Figueiredo \& Menezes, 2000; Watson, 1996l; Baldwin \& Smith; 2003; Yeung \&; Ruple, 2006b; Fahay, 2007. 


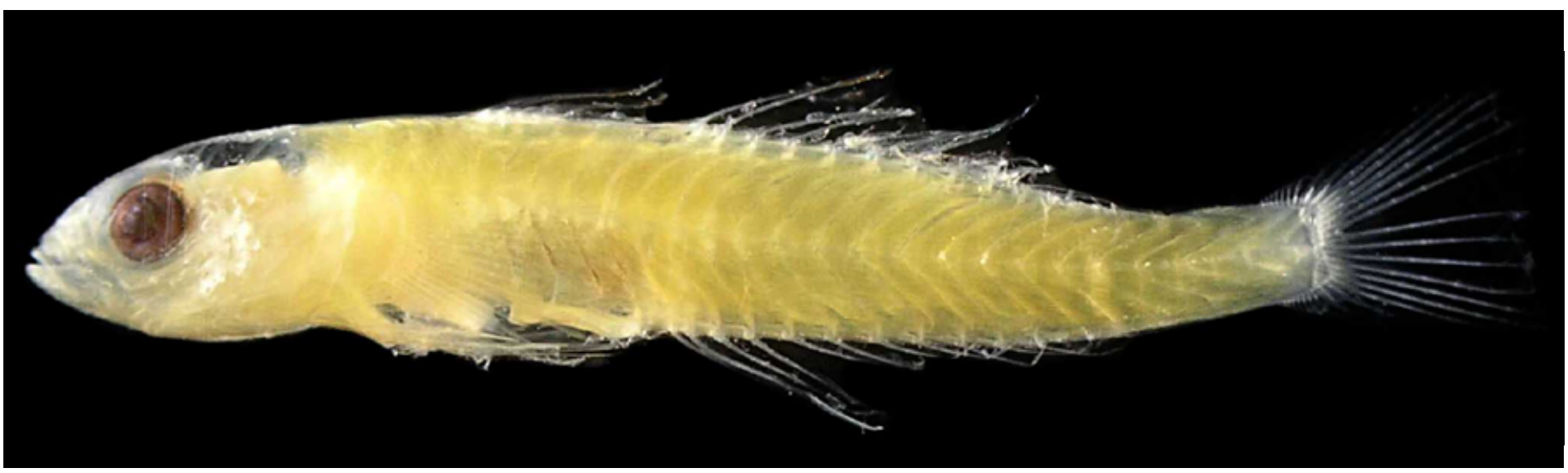

Figura 137: Gnatholepis thompsoni. DZUFRJ 22242; Pós-flexão; CP 10,5 mm.

\section{Gnatholepis thompsoni Jordan, 1904}

As larvas apresentam corpo alongado (26 miômeros), com olhos relativamente grandes e arredondados. As bases das nadadeiras dorsal e anal são moderadamente longas e de comprimento semelhante (11 raios na dorsal e 12 raios na anal). A base da nadadeira pélvica é parcialmente unida na porção ventral do corpo. Nadadeira peitoral com 16-17 raios. A vesícula gasosa possui pigmentos na porção dorsal e posterior. A principal característica é a presença de melanóforos associados aos espinhos e raios anteriores da nadadeira dorsal. Distingue-se também pela ausência de melanóforos na linha ventral. Possui uma faixa de pigmentos abaixo e acima dos olhos; no opérculo; na região frontal e na base da dorsal.

Tamanho: pós-flexão 10,5 mm.

Habitat: espécie marinha, demersal, ocorre em águas tropicais até 30 $\mathrm{m}$ de profundidade. Vive próximo ao substrato e rochas da plataforma continental.

Nome vulgar: Amoré de mancha dourada.

\section{Georreferenciamento}

\begin{tabular}{|c|c|c|c|c|c|c|c|c|}
\hline DZUFRJ & Latitude (S) & Longitude (W) & Data & $\begin{array}{c}\text { Tipo de } \\
\text { arrasto }\end{array}$ & $\begin{array}{c}\text { Profundidade } \\
\text { de coleta }\end{array}$ & Rede & $\begin{array}{c}\text { Malha } \\
\text { ( } \boldsymbol{\mu m})\end{array}$ & $\begin{array}{c}\mathbf{N}^{\circ} \text {. de } \\
\text { inds. }\end{array}$ \\
\hline 22242 & $22^{\circ} 32^{\prime} 03,0^{\prime \prime}$ & $040^{\circ} 17^{\prime} 21,0^{\prime \prime}$ & $19 / 05 / 2002$ & oblíquo & $30 \mathrm{~m}$ & bongô & 330 & 1 \\
\hline
\end{tabular}

Referências: Figueiredo \& Menezes, 2000; Watson, 1996l; Baldwin \& Smith; 2003; Yeung \&; Ruple, 2006b; Fahay, 2007. 


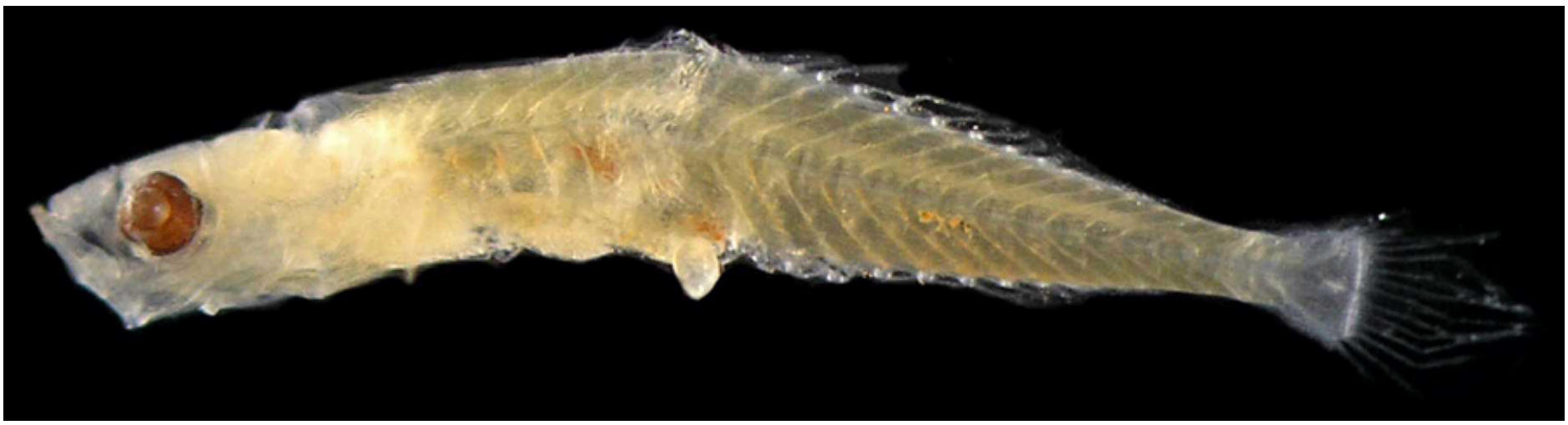

Figura 138 - A: Gobiidae sp. 1. DZUFRJ 22241; Flexão; CP 3,0 mm.

\section{Gobiidae sp. 1}

Os exemplares que foram tipados nesse grupo são caracterizados pela presença de pigmentos entre os miômeros em flexão e pós-flexão. Presença de pigmentação na porção dorsal e posterior da vesícula gasosa, na extremidade da maxila

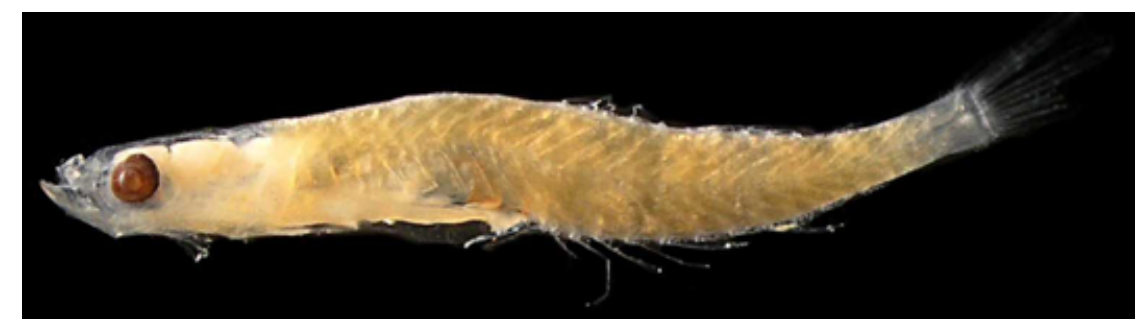

Figura 138 - B: DZUFRJ 22244; Pós-flexão; CP 6,5 mm. inferior. Na base da nadadeira anal há quatro manchas ventrais. A nadadeira dorsal é separada e a segunda possui 10 raios; nadadeira anal formada por 11-12 raios.

Tamanho: flexão 2,6-5,5 mm; pós-flexão 5,6-6,5 mm.

Habitat: as espécies de Gobiidae são costeiras e estuarinas, mas algumas podem ocorrer em águas oceânicas.

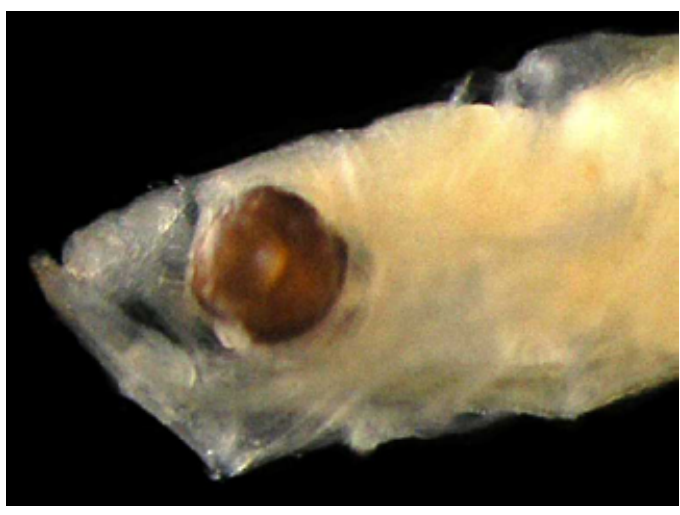

Figura 138 - C: Pigmentação na extremidade da maxila inferior.

\section{Georreferenciamento}

\begin{tabular}{|c|c|c|c|c|c|c|c|c|}
\hline DZUFRJ & Latitude (S) & Longitude (W) & Data & $\begin{array}{l}\text { Tipo de } \\
\text { arrasto }\end{array}$ & $\begin{array}{l}\text { Profundidade } \\
\text { de coleta }\end{array}$ & Rede & $\begin{array}{c}\text { Malha } \\
(\mu \mathrm{m})\end{array}$ & $\begin{array}{l}\text { No. de } \\
\text { inds. }\end{array}$ \\
\hline 604 & $22^{\circ} 38^{\prime} 29,0^{\prime \prime}$ & $040^{\circ} 17^{\prime} 40,0^{\prime \prime}$ & $18 / 05 / 2002$ & oblíquo & $800 \mathrm{~m}$ & cilíndrico-cônica & 500 & 3 \\
\hline 624 & $22^{\circ} 42^{\prime} 06,0^{\prime \prime}$ & $040^{\circ} 14^{\prime} 26,0^{\prime \prime}$ & 19/05/2002 & oblíquo & $50 \mathrm{~m}$ & bongô & 500 & 4 \\
\hline 22241 & $22^{\circ} 33^{\prime} 47,7^{\prime \prime}$ & $040^{\circ} 12^{\prime} 20,5^{\prime \prime}$ & $17 / 05 / 2002$ & oblíquo & $50 \mathrm{~m}$ & bongô & 330 & 3 \\
\hline 22244 & $21^{\circ} 53^{\prime} 10,4^{\prime \prime}$ & $039^{\circ} 45^{\prime} 49,9^{\prime \prime}$ & $10 / 10 / 2001$ & oblíquo & $1.000 \mathrm{~m}$ & cilíndrico-cônica & 500 & 1 \\
\hline 22259 & $22^{\circ} 38^{\prime} 25,0^{\prime \prime}$ & $040^{\circ} 17^{\prime} 41,0^{\prime \prime}$ & 19/05/2002 & oblíquo & $40 \mathrm{~m}$ & bongô & 330 & 2 \\
\hline 22260 & $22^{\circ} 36^{\prime} 54,9^{\prime \prime}$ & $040^{\circ} 09^{\prime} 19,4^{\prime \prime}$ & $16 / 05 / 2002$ & oblíquo & $50 \mathrm{~m}$ & bongô & 330 & 27 \\
\hline 22261 & $22^{\circ} 33^{\prime} 37,0^{\prime \prime}$ & $040^{\circ} 19^{\prime} 10,0^{\prime \prime}$ & $17 / 05 / 2002$ & oblíquo & $50 \mathrm{~m}$ & bongô & 500 & 3 \\
\hline 22262 & $22^{\circ} 38^{\prime} 25,0^{\prime \prime}$ & $040^{\circ} 17^{\prime} 41,0^{\prime \prime}$ & $19 / 05 / 2002$ & oblíquo & $40 \mathrm{~m}$ & bongô & 500 & 1 \\
\hline 22263 & $22^{\circ} 36^{\prime} 54,9^{\prime \prime}$ & $040^{\circ} 09^{\prime} 19,4^{\prime \prime}$ & $16 / 05 / 2002$ & oblíquo & $50 \mathrm{~m}$ & bongô & 500 & 3 \\
\hline 22264 & $22^{\circ} 34^{\prime} 05,0^{\prime \prime}$ & $040^{\circ} 19^{\prime} 40,0^{\prime \prime}$ & $17 / 05 / 2002$ & oblíquo & $600 \mathrm{~m}$ & cilíndrico-cônica & 500 & 4 \\
\hline 22265 & $22^{\circ} 41^{\prime} 54,7^{\prime \prime}$ & $040^{\circ} 14^{\prime} 04,5^{\prime \prime}$ & $16 / 05 / 2002$ & oblíquo & $1.000 \mathrm{~m}$ & cilíndrico-cônica & 500 & 4 \\
\hline
\end{tabular}

Referências: Figueiredo \& Menezes, 2000; Watson, 1996l; Baldwin \& Smith; 2003; Yeung \&; Ruple, 2006b; Fahay, 2007. 


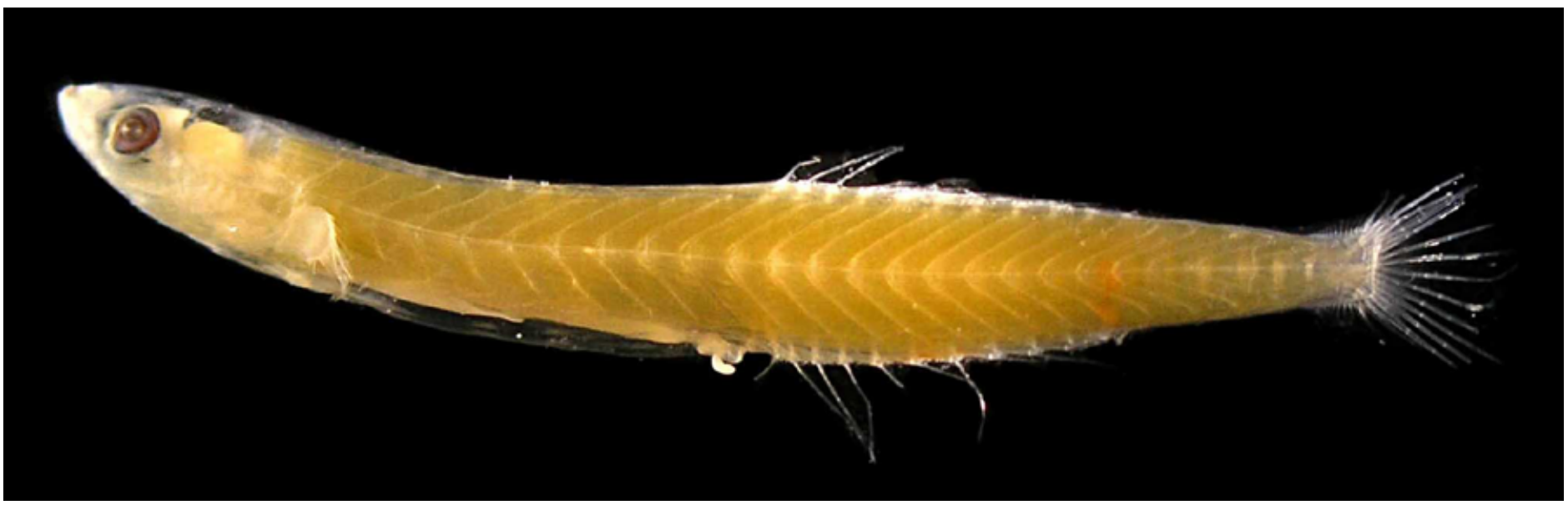

Figura 139: Gobionellus sp. 1. DZUFRJ 22285; Pós-flexão; CP 13,5 mm.

\section{Gobionellus sp. 1}

Possuem o corpo muito alongado (26 miômeros) e a cabeça afilada com pigmentação na extremidade da mandíbula. Presença de 11 raios na segunda nadadeira dorsal e 12 raios na nadadeira anal. Pigmentação presente na porção posterior da vesícula gasosa. Apresentam uma mancha de pigmentos na base da nadadeira anal, entre o sexto e o oitavo raios. Na região do pedúnculo caudal, há um pigmento ventral (interno e superficial), com origem no último raio da nadadeira anal, que se estende acima da linha lateral. No Brasil já foram registradas as espécies Gobionellus oceanicus (Pallas, 1770), Gobionellus stomatus Starks, 1913 e Gobionellus thoropsis Pezold \& Gilbert, 1987.

Tamanho: pós-flexão 13,5-14,5 mm.

Habitat: as espécies de Gobionellus vivem em regiões costeiras, com ampla variação de salinidade.

\section{Georreferenciamento}

\begin{tabular}{|c|c|c|c|c|c|c|c|c|}
\hline DZUFRJ & Latitude (S) & Longitude (W) & Data & $\begin{array}{c}\text { Tipo de } \\
\text { arrasto }\end{array}$ & $\begin{array}{c}\text { Profundidade } \\
\text { de coleta }\end{array}$ & Rede & $\begin{array}{c}\text { Malha } \\
(\boldsymbol{\mu m})\end{array}$ & $\begin{array}{c}\mathbf{N}^{\circ} \text {. de } \\
\text { inds. }\end{array}$ \\
\hline 22285 & $22^{\circ} 02^{\prime} 30,0^{\prime \prime}$ & $039^{\circ} 49^{\prime} 41,2^{\prime \prime}$ & $12 / 05 / 2002$ & oblíquo & $1.000 \mathrm{~m}$ & cilíndrico-cônica & 500 & 2 \\
\hline
\end{tabular}

Referências: Figueiredo \& Menezes, 2000; Watson, 1996l; Baldwin \& Smith; 2003; Yeung \&; Ruple, 2006b; Fahay, 2007. 


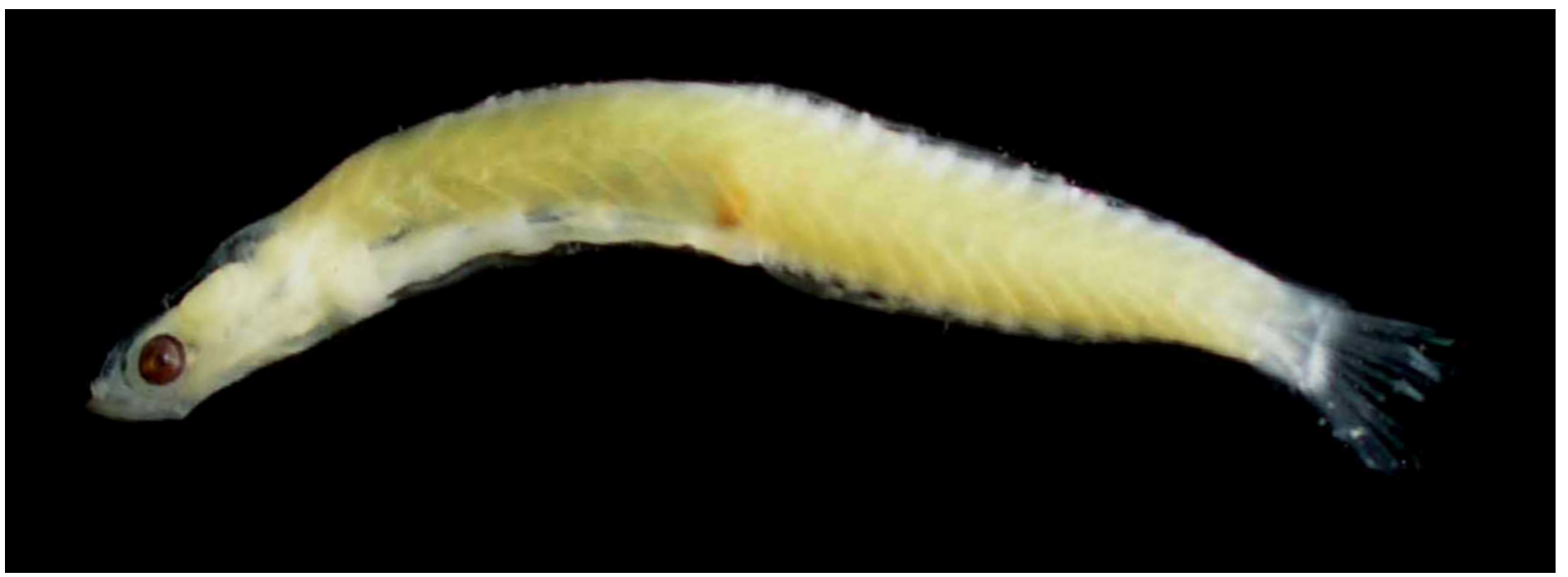

Figura 140: Gobionellus sp. 2. DZUFRJ 22286; Pós-flexão; CP 9,0 mm.

\section{Gobionellus sp. 2}

Possuem o corpo muito alongado (26 miômeros) e a cabeça afilada, com pigmentação na extremidade das maxilas. Presença de 13 raios na segunda nadadeira dorsal e na nadadeira anal. A vesícula gasosa possui pigmentação apenas na porção posterior.

Tamanho: pós-flexão 9,0 mm.

Habitat: as espécies de Gobionellus vivem em regiões costeiras, com ampla variação de salinidade. No Brasil já foram registradas as espécies Gobionellus oceanicus (Pallas, 1770), Gobionellus stomatus Starks, 1913, Gobionellus thoropsis Pezold \& Gilbert, 1987.

\section{Georreferenciamento}

\begin{tabular}{|c|c|c|c|c|c|c|c|c|}
\hline DZUFRJ & Latitude (S) & Longitude (W) & Data & $\begin{array}{c}\text { Tipo de } \\
\text { arrasto }\end{array}$ & $\begin{array}{c}\text { Profundidade } \\
\text { de coleta }\end{array}$ & Rede & $\begin{array}{c}\text { Malha } \\
\text { ( } \boldsymbol{\mu m})\end{array}$ & $\begin{array}{c}\mathbf{N}^{\circ} \text {. de } \\
\text { inds. }\end{array}$ \\
\hline 22286 & $22^{\circ} 08^{\prime} 175^{\prime \prime}$ & $039^{\circ} 46^{\prime} 28,5^{\prime \prime}$ & $11 / 05 / 2002$ & oblíquo & $1.000 \mathrm{~m}$ & cilíndrico-cônica & 500 & 1 \\
\hline
\end{tabular}

Referências: Figueiredo \& Menezes, 2000; Watson, 1996l; Baldwin \& Smith; 2003; Yeung \&; Ruple, 2006b; Fahay, 2007. 


\section{Família Microdesmidae}

É formada por peixes marinhos, raramente de água doce e salobra, que ocorrem em regiões tropicais e subtropicais. Compreende 10 gêneros com aproximadamente 66 espécies. A primeira nadadeira dorsal possui X - XXVIII espinhos e a segunda tem 23 a 61 raios. O corpo é relativamente longo e o pedúnculo caudal é curto. A pigmentação na vesícula gasosa se restringe à superfície dorsal.

No Brasil já foram identificadas quatro espécies nas fases de larva e adulto: Cerdale fasciata Dawson, 1974; Microdesmus bahianus Dawson, 1973; Microdesmus longipinnis (Weymouth, 1910) e Ptereleotris randalli Gasparini, Rocha \& Floeter, 2001. Nesse estudo é contemplada a espécie Ptereleotris randalli Gasparini, Rocha \& Floeter, 2001. Essa espécie fazia parte da família Ptereleotridae que passou a ser reconhecida como subfamília (Ptereleotrinae) de Microdesmidae. 


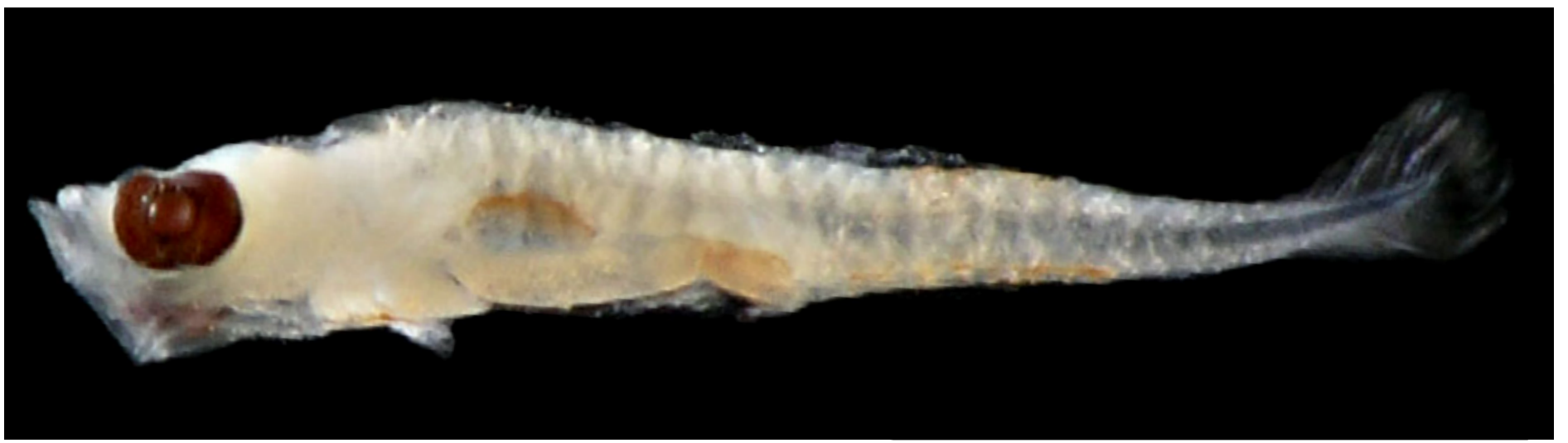

Figura 141 - A: Ptereleotris randalli. DZUFRJ 535; Pré-flexão; CP 3,0 mm.

\section{Ptereleotris} randalli

\section{Gasparini, Rocha \& Floeter, 2001}

Possui o corpo alongado (26 miômeros) e a região do pedúnculo caudal muito curta. É caracterizada pelo grande comprimento da base da segunda nadadeira dorsal, com 26-28 raios. Na pré-flexão possui manchas estreladas na porção posterior da cabeça, pigmentos sobre a vesícula gasosa e porção final do intestino, e uma fileira única de pigmentos na região dorsal no terço final da larva. A partir da flexão $(3,5 \mathrm{~mm})$ a fileira de pigmentos na região dorsal já é dupla. Essa dupla fileira começa no $2^{\circ}$ raio da $2^{a}$ nadadeira dorsal e torna-se mais unida em direção à nadadeira caudal. Na margem ventral do corpo também são encontrados pigmentos que ficam mais espaçados durante os estágios de flexão e de pós-flexão.

Tamanho: pré-flexão 2,5-3,0 mm; flexão 3,57,5 mm; pós-flexão 11,7 mm.

Habitat: espécie marinha, demersal, ocorre em águas tropicais entre 8 e $60 \mathrm{~m}$ de profundidade.

Nome vulgar: Linha azul.

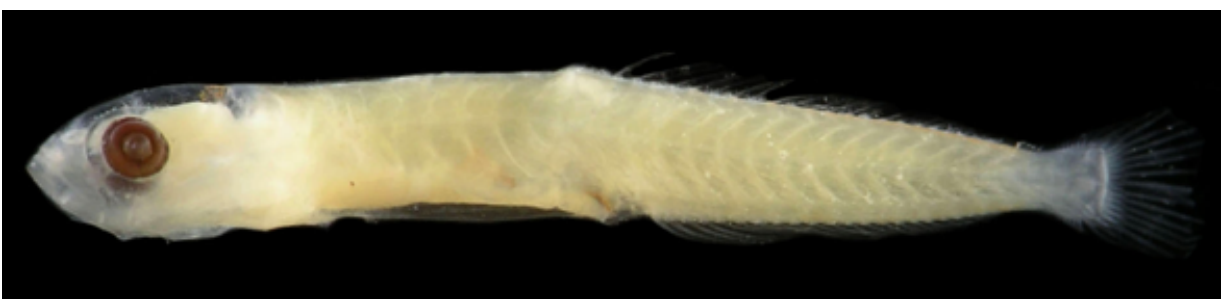

Figura 141 - B: DZUFRJ 646; Flexão; CP 7,0 mm.

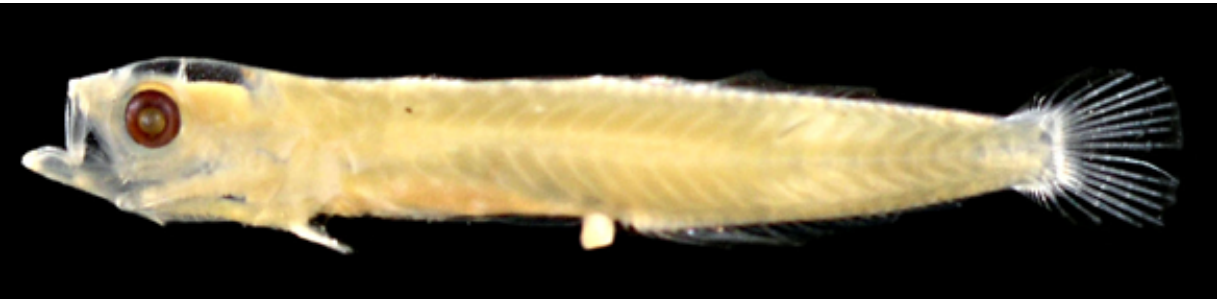

Figura 141 - C: DZUFRJ 1221; Pós-flexão; CP 11,7 mm.

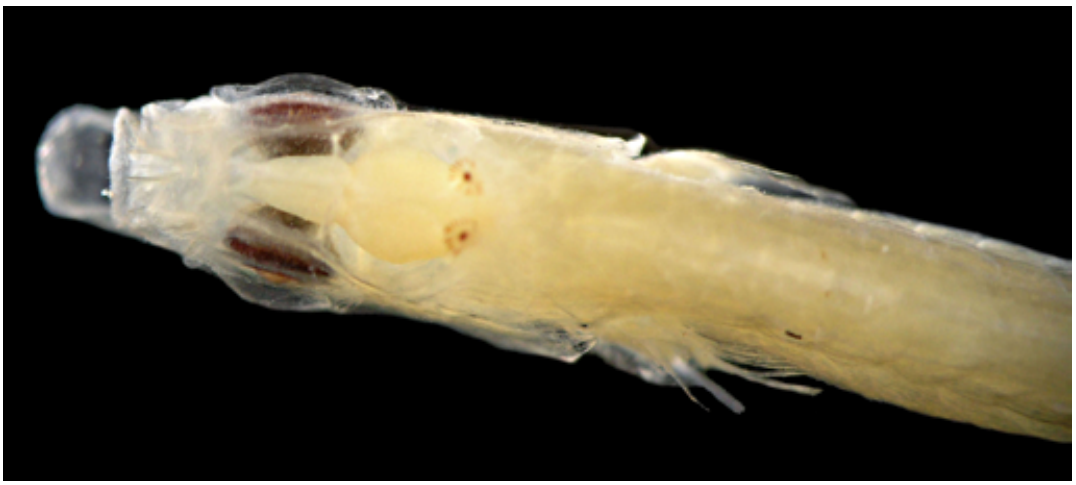

Figura 141 - D: Manchas estreladas na porção posterior da cabeça.

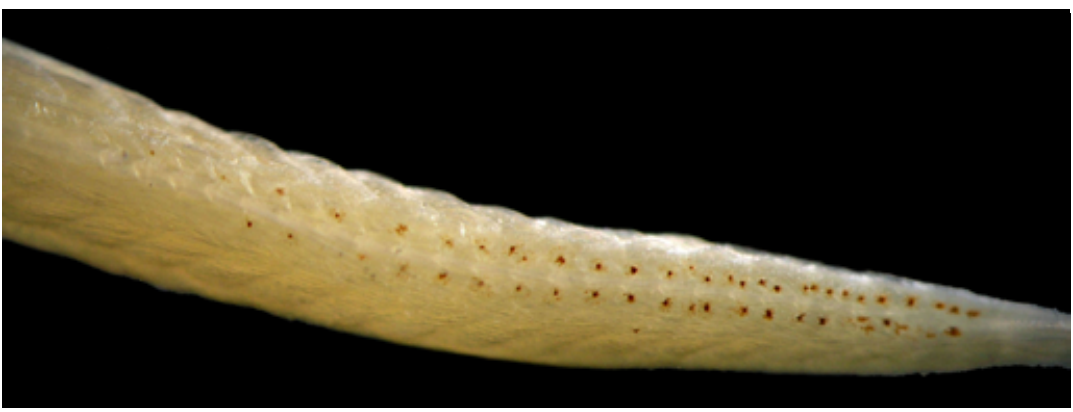

Figura 141 - E: Fileira dupla de melanóforos na região dorsal. 


\section{Georreferenciamento}

\begin{tabular}{|c|c|c|c|c|c|c|c|c|}
\hline DZUFR & Latitude (S) & Longitude (W) & Data & $\begin{array}{c}\text { Tipo de } \\
\text { arrasto }\end{array}$ & $\begin{array}{c}\text { Profundidade } \\
\text { de coleta }\end{array}$ & Rede & $\begin{array}{c}\text { Malha } \\
\text { ( } \boldsymbol{\mu m} \text { ) }\end{array}$ & $\begin{array}{c}\text { No. de } \\
\text { inds. }\end{array}$ \\
\hline 488 & $22^{\circ} 33^{\prime} 37,0^{\prime \prime}$ & $040^{\circ} 19^{\prime} 10,0^{\prime \prime}$ & $17 / 05 / 2002$ & oblíquo & $50 \mathrm{~m}$ & bongô & 500 & 30 \\
\hline 512 & $22^{\circ} 31^{\prime} 27,0^{\prime \prime}$ & $040^{\circ} 16^{\prime} 56,0^{\prime \prime}$ & $17 / 05 / 2002$ & oblíquo & $600 \mathrm{~m}$ & cilíndrico-cônica & 500 & 37 \\
\hline 529 & $22^{\circ} 34^{\prime} 05,0^{\prime \prime}$ & $040^{\circ} 19^{\prime} 40,0^{\prime \prime}$ & $17 / 05 / 2002$ & oblíquo & $600 \mathrm{~m}$ & cilíndrico-cônica & 500 & 48 \\
\hline 575 & $22^{\circ} 33^{\prime} 477^{\prime \prime}$ & $040^{\circ} 12^{\prime} 20,5^{\prime \prime}$ & $17 / 05 / 2002$ & oblíquo & $50 \mathrm{~m}$ & bongô & 330 & 2 \\
\hline 591 & $22^{\circ} 33^{\prime} 45,8^{\prime \prime}$ & $040^{\circ} 13^{\prime} 22,9^{\prime \prime}$ & $17 / 05 / 2002$ & oblíquo & $800 \mathrm{~m}$ & cilíndrico-cônica & 500 & 5 \\
\hline 646 & $22^{\circ} 38^{\prime} 25,0^{\prime \prime}$ & $040^{\circ} 17^{\prime} 41,0^{\prime \prime}$ & $19 / 05 / 2002$ & oblíquo & $40 \mathrm{~m}$ & bongô & 330 & 34 \\
\hline 1221 & $22^{\circ} 02^{\prime} 30,0^{\prime \prime}$ & $039^{\circ} 49^{\prime} 41,2^{\prime \prime}$ & $12 / 05 / 2002$ & oblíquo & $1.000 \mathrm{~m}$ & cilíndrico-cônica & 500 & 1 \\
\hline 1357 & $22^{\circ} 02^{\prime} 30,0^{\prime \prime}$ & $039^{\circ} 49^{\prime} 41,2^{\prime \prime}$ & $12 / 05 / 2002$ & oblíquo & até a termoclina & bongô & 330 & 2 \\
\hline
\end{tabular}

Referências: Gasparini et al., 2001; Baldwin \& Smith; 2003; Watson \& Walker, 2006; Fahay, 2007; Gomes \& Bonecker, 2014. 


\section{Família Acanthuridae}

Os membros da família Acanthuridae são encontrados em águas tropicais, subtropicais e, algumas vezes, temperadas dos oceanos Atlântico e Pacífico. Compreende seis gêneros com aproximadamente 80 espécies. Os adultos liberam larvas planctônicas que vivem 45-70 dias em águas pelágicas. Os representantes desta família têm um estágio pós-larval especializado, conhecido como acronurus. Esse estágio é caracterizado pela forma arredondada e quase total transparência do corpo, exceto em relação aos pigmentos internos no intestino e na cabeça.

No Brasil, já foram identificadas quatro espécies nas fases de larva e adulto: Acanthurus bahianus Castelnau, 1855; Acanthurus chirurgus (Bloch, 1787); Acanthurus coerulus Bloch \& Schneider, 1801 e Acanthurus monroviae Steindachner, 1876. Nesse estudo é contemplada a espécie Acanthurus sp. 


\section{Acanthurus sp.}

As larvas de Acanthurus possuem o corpo com formato discoide, comprimido lateralmente e boca pequena. Desenvolvem espinhos na cabeça, mas não há espinhos no opérculo. A principal característica é a presença de um pequeno espinho retroarticular, localizado em ambos os lados do pedúnculo caudal. A separação das espécies é baseada nos dados merísticos. As larvas utilizadas nesse estudo estavam no estágio de pré-flexão e os raios não estavam formados, o que impossibilitou a identificação até espécie. Número total de miômeros: 22.

Tamanho: pré-flexão 2,6-3,2 mm.

Habitat: as espécies de Acanthurus são marinhas, pelágicas, vivem associadas a formações coralinas e rochas, misturadas ao fundo arenoso.

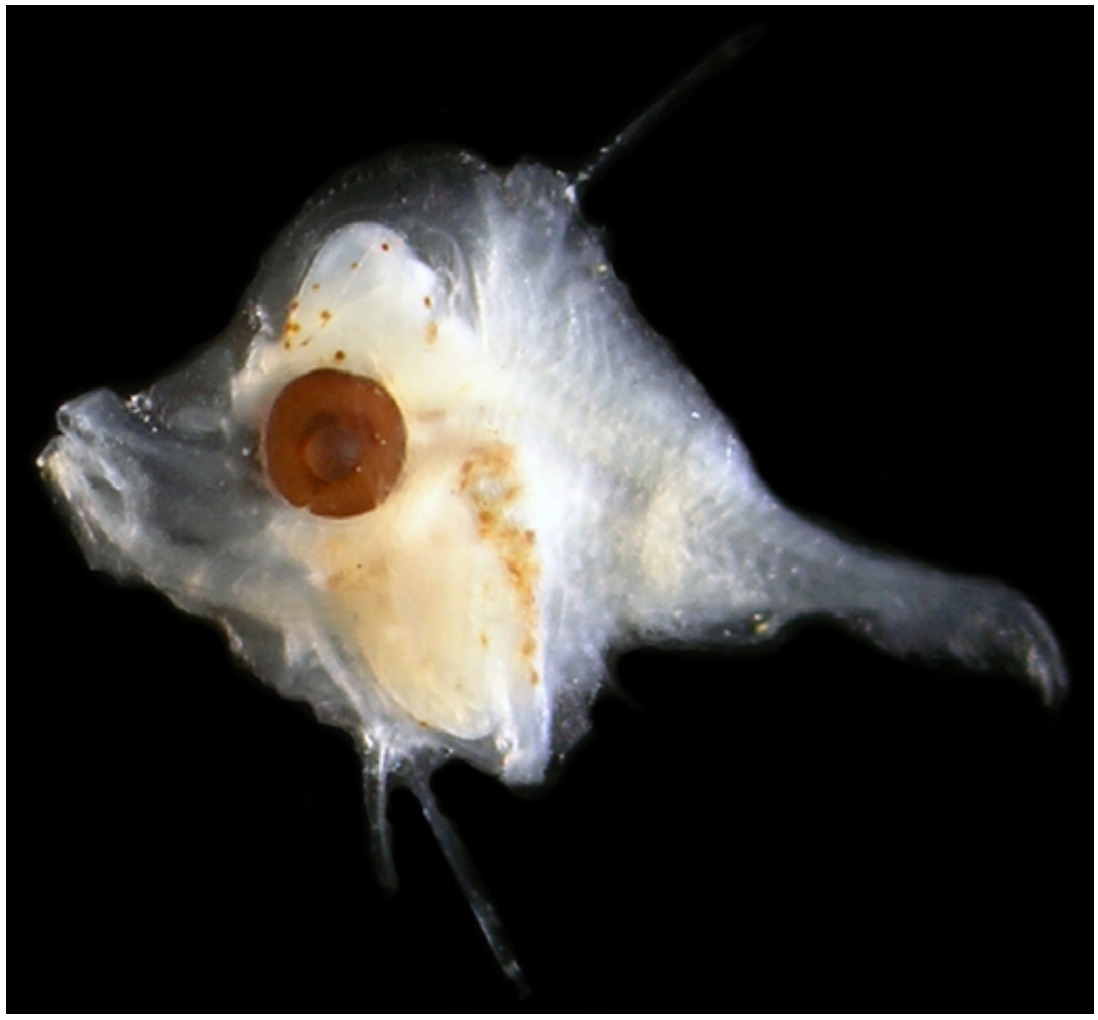

Figura 142: Acanthurus sp. DZUFRJ 464; Pré-flexão; CP 3,2 mm.

\section{Georreferenciamento}

\begin{tabular}{|c|c|c|c|c|c|c|c|c|}
\hline DZUFRJ & Latitude (S) & Longitude (W) & Data & $\begin{array}{c}\text { Tipo de } \\
\text { arrasto }\end{array}$ & $\begin{array}{c}\text { Profundidade } \\
\text { de coleta }\end{array}$ & Rede & $\begin{array}{c}\text { Malha } \\
\text { ( } \boldsymbol{\mu m})\end{array}$ & $\begin{array}{c}\mathbf{N}^{\circ} \text {. de } \\
\text { inds. }\end{array}$ \\
\hline 464 & $22^{\circ} 33^{\prime} 477^{\prime \prime}$ & $040^{\circ} 12^{\prime} 20,5^{\prime \prime}$ & $17 / 05 / 2002$ & oblíquo & $50 \mathrm{~m}$ & bongô & $330 \mu \mathrm{m}$ & 1 \\
\hline 671 & $22^{\circ} 41^{\prime} 54,7^{\prime \prime}$ & $040^{\circ} 14^{\prime} 04,5^{\prime \prime}$ & $16 / 05 / 2002$ & oblíquo & $1000 \mathrm{~m}$ & cilíndrico-cônica & $500 \mu \mathrm{m}$ & 1 \\
\hline
\end{tabular}

Referências: Leis \& Richards, 1984; Rocha et al., 2002; Luiz-Júnior et al., 2004; Jackson, 2006b; Fahay, 2007. 


\section{Família Sphyraenidae}

Os representantes da família Sphyraenidae são encontradas em regiões temperadas e tropicais em todo mundo. São pelágicos e ocorrem, principalmente, em águas próximas a plataforma e em regiões de fundo rígido. A família compreende um gênero e aproximadamente 21 espécies.

As larvas são caracterizadas pela presença da nadadeira pélvica na região abdominal. As nadadeiras dorsais são bem separadas, sendo a primeira com $V$ espinhos e a segunda I, 8-10. A anal é formada por um a três espinhos e sete a nove raios. O corpo (24 miômeros) e o focinho são moderadamente alongados. A maxila superior não é protrátil, enquanto a inferior se projeta além da superior. As larvas e os adultos são separados pelo padrão de pigmentação, presença ou ausência de uma protuberância da maxila inferior, comprimento da nadadeira peitoral e a posição da primeira dorsal, em relação a origem das nadadeiras anal e pélvica.

No Brasil, já foram identificadas quatro espécies nas fases de larva e adulto: Sphyraena barracuda (Walbaum, 1792); Sphyraena guachancho Cuvier, 1829; Sphyraena sphyraena (Linnaeus, 1758) e Sphyraena tome Fowler, 1903. Nesse estudo é contemplada a espécie Sphyraena guachancho. 


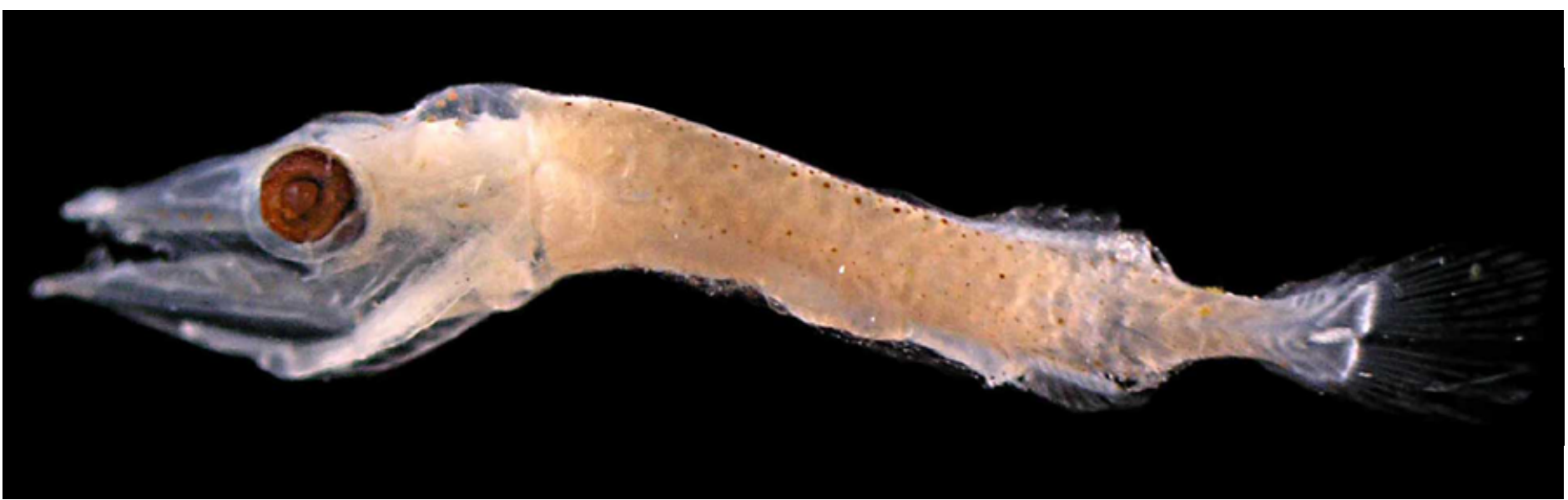

Figura 143: Sphyraena guachancho. DZUFRJ 351; Flexão; CP 5,4 mm.

\section{Sphyraena guachancho Cuvier, 1829}

As larvas apresentam o corpo moderadamente alongado (24 miômeros). O intestino é comprido chegando a $65 \%$ do CP, aumentando até $70 \%$ do CP com o crescimento. A cabeça também aumenta de comprimento de acordo com o crescimento da larva, passando de $27 \%$ para $38 \%$ do CP. O focinho é muito pontudo, sendo que a maxila inferior estende-se além da inferior. Os pigmentos estão presentes na maxila inferior, no focinho, na margem ventral do intestino e nas linhas dorsal, ventral e lateral do corpo. Os melanóforos são mais densos nas margens dorsal e ventral do corpo e da cauda, sendo a região do intestino pouco pigmentada. A pigmentação da cabeça é ausente em estágios menores, aparecendo fracamente nos estágios mais desenvolvidos.

Tamanho: flexão 5,4 mm.

Habitat: espécie marinha, pelágica, ocorre em águas subtropicais desde próximo à superfície até $100 \mathrm{~m}$ de profundidade. Vive em águas costeiras, com alta turbidez, podendo ocorrer também em regiões estuarinas.

Nome vulgar: Bicuda branca.

Georreferenciamento

\begin{tabular}{|c|c|c|c|c|c|c|c|c|}
\hline DZUFRJ & Latitude (S) & Longitude (W) & Data & $\begin{array}{c}\text { Tipo de } \\
\text { arrasto }\end{array}$ & $\begin{array}{c}\text { Profundidade } \\
\text { de coleta }\end{array}$ & Rede & $\begin{array}{c}\text { Malha } \\
(\boldsymbol{\mu m})\end{array}$ & $\begin{array}{c}\mathbf{N}^{\circ} \text {. de } \\
\text { inds. }\end{array}$ \\
\hline 351 & $22^{\circ} 31^{\prime} 27,0^{\prime \prime}$ & $040^{\circ} 16^{\prime} 56,0^{\prime \prime}$ & $17 / 05 / 2002$ & oblíquo & $600 \mathrm{~m}$ & cilíndrico-cônica & 500 & 1 \\
\hline
\end{tabular}

Referências: Menezes \& Figueiredo, 1985; Sandknop \& Watson, 1996b; Matsuura \& Suzuki, 1997; Russell, 2002; Ditty et al., 2006; Fahay, 2007. 


\section{Família Gempylidae}

As larvas pertencentes a família Gempylidae vivem em zonas pelágicas de regiões tropicais e temperadas, em todo mundo. Quando adultos, apresentam ampla distribuição geográfica, vivendo em zonas mesopelágicas. A família compreende 16 gêneros e aproximadamente 24 espécies.

As larvas têm espinhos proeminentes e a contagem dos elementos das nadadeiras é importante para a separação das espécies. O formato do corpo é variado, desde muito alongado até fusiforme. Há dois orifícios nasais de cada lado do focinho. A primeira nadadeira dorsal é muito desenvolvida, sendo maior que a segunda. A nadadeira caudal é furcada e a pélvica é pouco desenvolvida, podendo estar ausente nos adultos de algumas espécies.

No Brasil, já foram identificadas dez espécies nas fases de larva e adulto. Nesse estudo são contempladas as espécies Diplospinus multistriatus, Gempylus serpens, Lepidocybium flavobrunneum e Nesiarchus nasutus. 


\section{Diplospinus multistriatus Maul, 1948}

Nadadeira dorsal: XXX-XXXVI+I, 35-41. Nadadeira anal: II, 29-35. O corpo é mais alto na região peitoral e fino na região do pedúnculo caudal. O número de miômeros varia entre 58-61. O focinho é alongado e pontudo. Presença de espinhos na cabeça que são característicos dessa espécie. 0 espinho da nadadeira pélvica é muito longo e serrilhado. As lar-

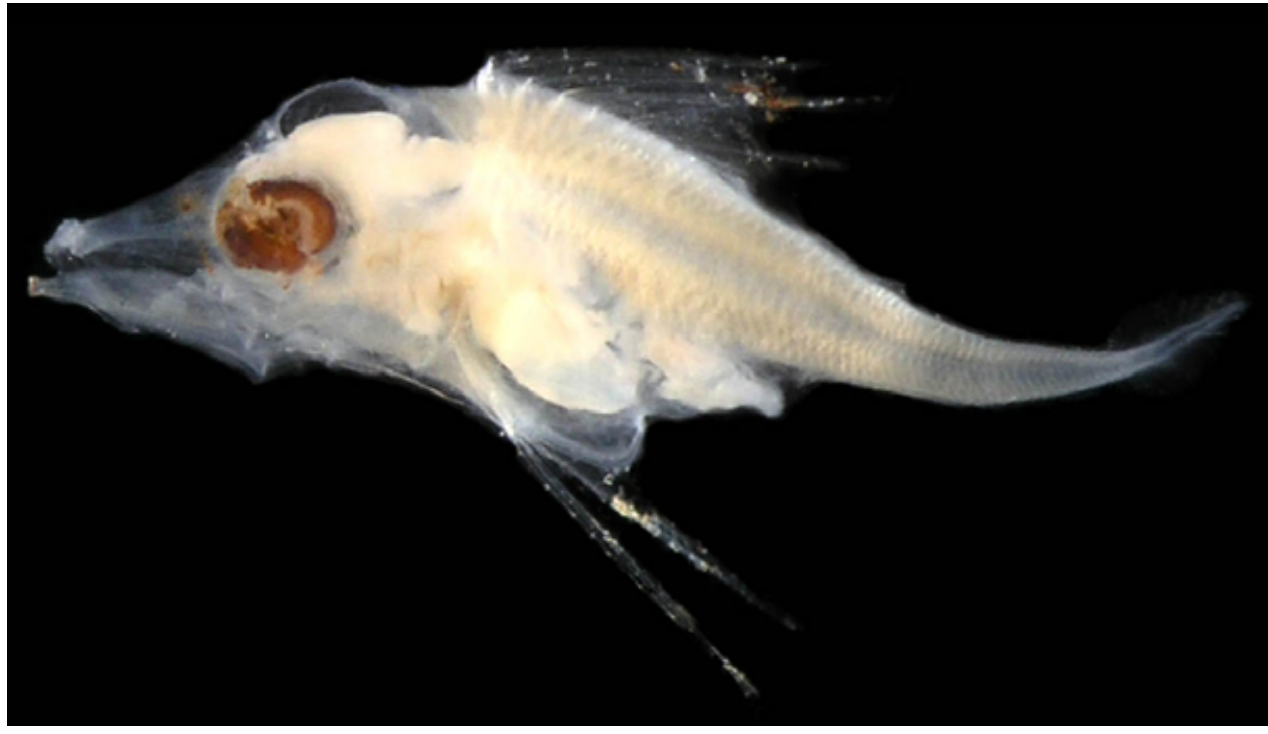

Figura 144 A: Diplospinus multistriatus. DZUFRJ 19772; Pré-flexão; CP 5,7 mm. vas apresentam pigmentos na região mediana e posterior da cabeça, sobre o intestino, na extremidade da maxila inferior e atrás dos olhos. Diferenciam-se pela pigmentação presente na membrana entre os espinhos da primeira nadadeira dorsal e na margem dorsal do corpo.

Tamanho: pré-flexão 4,2-8,5 mm; flexão 9,1 mm.

Habitat: espécie marinha, mesopelágica, ocorre até $1.000 \mathrm{~m}$ de profundidade.

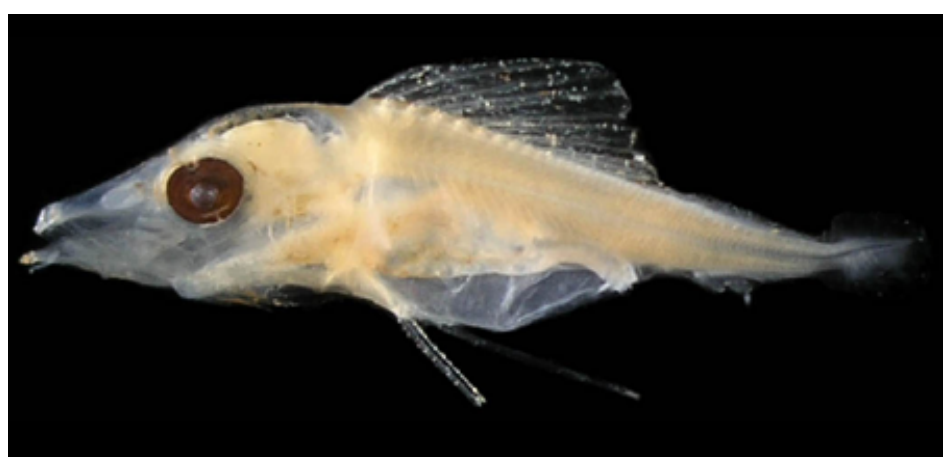

Figura 144 B: DZUFRJ 7430; Flexão; CP 9,1 mm.

\section{Georreferenciamento}

\begin{tabular}{|c|c|c|c|c|c|c|c|c|}
\hline DZUFRJ & Latitude (S) & Longitude (W) & Data & $\begin{array}{c}\text { Tipo de } \\
\text { arrasto }\end{array}$ & $\begin{array}{c}\text { Profundidade } \\
\text { de coleta }\end{array}$ & Rede & $\begin{array}{c}\text { Malha } \\
(\boldsymbol{\mu m})\end{array}$ & $\begin{array}{c}\text { No. de } \\
\text { inds. }\end{array}$ \\
\hline 5492 & $22^{\circ} 32^{\prime} 50,0^{\prime \prime}$ & $040^{\circ} 04^{\prime} 099^{\prime \prime}$ & $06 / 11 / 2001$ & oblíquo & $1.000 \mathrm{~m}$ & cilíndrico-cônica & 500 & 1 \\
\hline 7427 & $21^{\circ} 54^{\prime} 36,5^{\prime \prime}$ & $039^{\circ} 45^{\prime} 20,0^{\prime \prime}$ & $09 / 10 / 2001$ & oblíquo & $1.000 \mathrm{~m}$ & cilíndrico-cônica & 500 & 2 \\
\hline 7430 & $21^{\circ} 53^{\prime} 10,4^{\prime \prime}$ & $039^{\circ} 45^{\prime} 49,9^{\prime \prime}$ & $10 / 10 / 2001$ & oblíquo & $1.000 \mathrm{~m}$ & cilíndrico-cônica & 500 & 2 \\
\hline 19772 & $22^{\circ} 32^{\prime} 50,0^{\prime \prime}$ & $040^{\circ} 04^{\prime} 09^{\prime \prime}$ & $06 / 11 / 2001$ & oblíquo & $1.000 \mathrm{~m}$ & cilíndrico-cônica & 500 & 2 \\
\hline
\end{tabular}

Referências: Ambrose, 1996d; Figueiredo \& Menezes, 2000; Richards, 2006i; Fahay, 2007. 


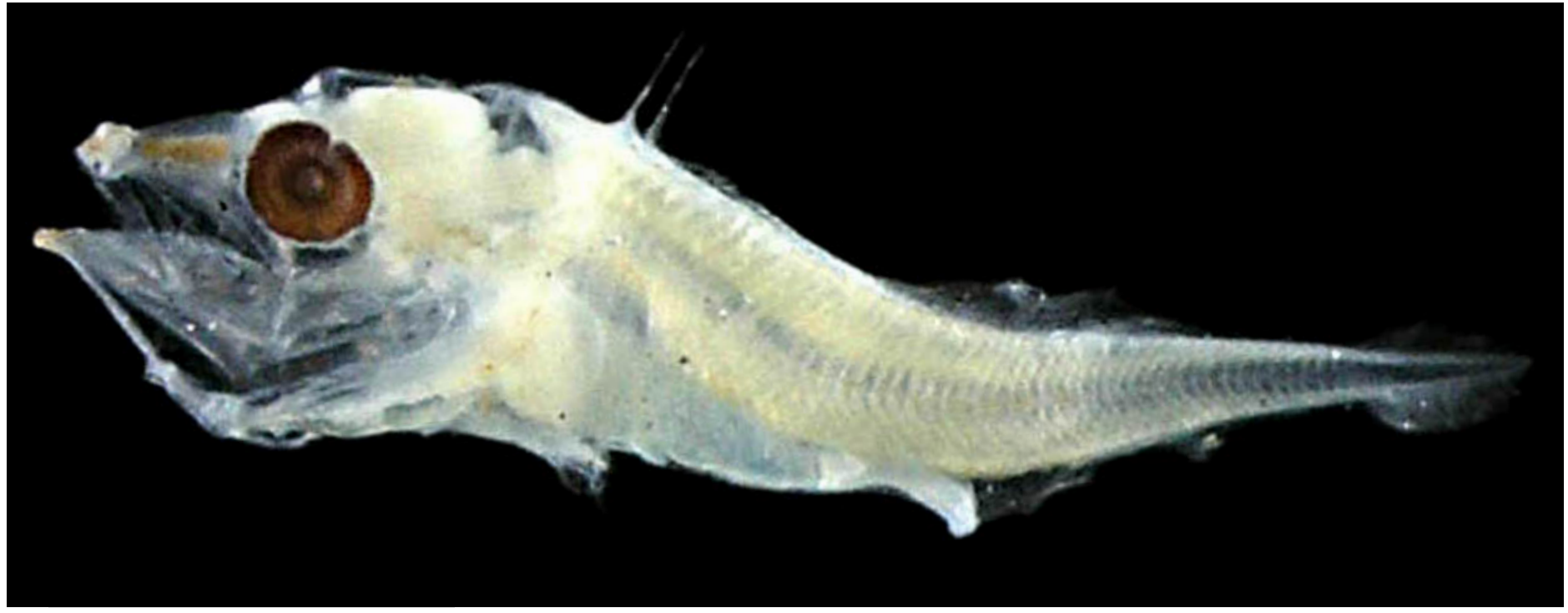

Figura 145 - A: Gempylus serpens. DZUFRJ 1295; Pré-flexão; CP 3,5 mm.

\section{Gempylus serpens Cuvier, 1829}

É a única espécie de Gempylidae que possui pigmentos ao longo da linha lateral do corpo durante todo desenvolvimento. O número de miômeros varia entre 51-55. Tem pigmentos nas regiões mediana e posterior da cabeça, sobre o intestino, no orifício nasal, na extremidade da mandíbula, nas margens ventral e dorsal da cauda, na primeira nadadeira dorsal e atrás dos olhos, desde a pré-flexão. A pigmentação sobre o dorso, nadadeira dorsal e intestino intensificam-se ao longo do desenvolvimento. Após a formação das nadadeiras, a presença de XXVVI-XXXII espinhos na primeira dorsal e I-Il espinhos e 10-14 raios na segunda dorsal são características diagnósticas dessa espécie.

Tamanho: pré-flexão 2,5-6,2 mm; flexão 6,7-9,0 mm; pós-flexão 10,5 mm.

Habitat: espécie marinha, epi-mesopelágica, ocorre em águas tropicais e subtropicais em profundidades superiores a $200 \mathrm{~m}$.

Nome vulgar: Lanceta.

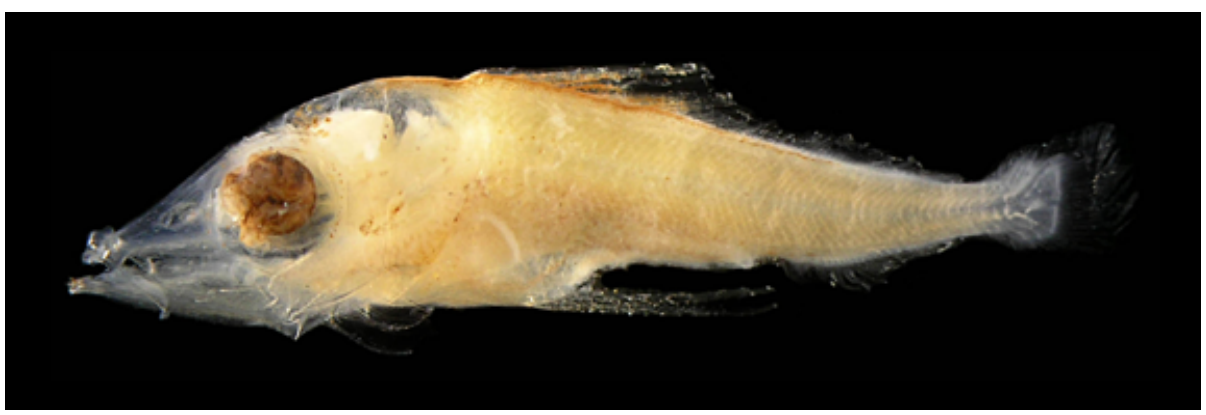

Figura 145 - B: DZUFRJ 7424; Flexão; CP 8,2 mm.

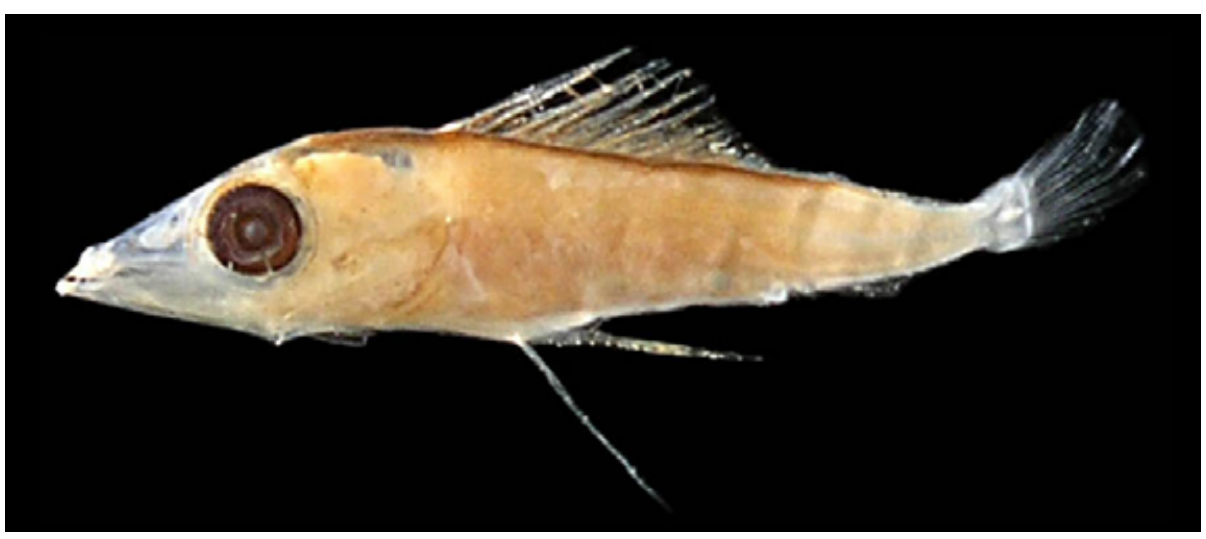

Figura 145 - C: DZUFRJ 7426; Pós-flexão; CP 10,5 mm. 


\section{Georreferenciamento}

\begin{tabular}{|c|c|c|c|c|c|c|c|c|}
\hline DZUFRJ & Latitude (S) & Longitude (W) & Data & $\begin{array}{l}\text { Tipo de } \\
\text { arrasto }\end{array}$ & $\begin{array}{l}\text { Profundidade } \\
\text { de coleta }\end{array}$ & Rede & $\begin{array}{l}\text { Malha } \\
(\mu \mathrm{m})\end{array}$ & $\begin{array}{l}N^{\circ} \text {. de } \\
\text { inds. }\end{array}$ \\
\hline 531 & $22^{\circ} 36^{\prime} 54,9^{\prime \prime}$ & $040^{\circ} 09^{\prime} 19,4^{\prime \prime}$ & $16 / 05 / 2002$ & oblíquo & $50 \mathrm{~m}$ & bongô & 330 & 1 \\
\hline 676 & $22^{\circ} 42^{\prime} 06,0^{\prime \prime}$ & $040^{\circ} 14^{\prime} 26,0^{\prime \prime}$ & $19 / 05 / 2002$ & oblíquo & $50 \mathrm{~m}$ & bongô & 330 & 2 \\
\hline 1187 & $22^{\circ} 07^{\prime} 29,0^{\prime \prime}$ & $039^{\circ} 06 ' 23,5^{\prime \prime}$ & $10 / 05 / 2002$ & oblíquo & $1.000 \mathrm{~m}$ & cilíndrico-cônica & 500 & 2 \\
\hline 1277 & $22^{\circ} 06^{\prime} 37,8^{\prime \prime}$ & $039^{\circ} 49^{\prime} 44,8^{\prime \prime}$ & $10 / 05 / 2002$ & oblíquo & até a termoclina & bongô & 500 & 2 \\
\hline 1284 & $22^{\circ} 06^{\prime} 52,3^{\prime \prime}$ & $039^{\circ} 48^{\prime} 46,2^{\prime \prime}$ & $11 / 05 / 2002$ & oblíquo & até a termoclina & bongô & 500 & 3 \\
\hline 1295 & $22^{\circ} 02^{\prime} 30,0^{\prime \prime}$ & $039^{\circ} 49^{\prime} 41,2^{\prime \prime}$ & $12 / 05 / 2002$ & oblíquo & até a termoclina & bongô & 500 & 2 \\
\hline 1328 & $22^{\circ} 03^{\prime} 03,3^{\prime \prime}$ & $039^{\circ} 50^{\prime} 39,0^{\prime \prime}$ & $10 / 05 / 2002$ & oblíquo & até a termoclina & bongô & 330 & 2 \\
\hline 1346 & $22^{\circ} 06^{\prime} 52,3^{\prime \prime}$ & $039^{\circ} 48^{\prime} 46,2^{\prime \prime}$ & $11 / 05 / 2002$ & oblíquo & até a termoclina & bongô & 330 & 9 \\
\hline 1387 & $22^{\circ} 08^{\prime} 14,9^{\prime \prime}$ & 03946'34,6"' & $11 / 05 / 2002$ & oblíquo & até a termoclina & bongô & 330 & 1 \\
\hline 5438 & $22^{\circ} 31^{\prime} 58,9^{\prime \prime}$ & $040^{\circ} 02^{\prime} 53,4^{\prime \prime}$ & $07 / 11 / 2001$ & oblíquo & $1.000 \mathrm{~m}$ & cilíndrico-cônica & 500 & 5 \\
\hline 5440 & $22^{\circ} 31^{\prime} 58,9^{\prime \prime}$ & $040^{\circ} 02^{\prime} 53,4^{\prime \prime}$ & $07 / 11 / 2001$ & oblíquo & $1.000 \mathrm{~m}$ & cilíndrico-cônica & 500 & 3 \\
\hline 5493 & $22^{\circ} 32^{\prime} 50,0^{\prime \prime}$ & $040^{\circ} 04^{\prime} 09,9^{\prime \prime}$ & $06 / 11 / 2001$ & oblíquo & $1.000 \mathrm{~m}$ & cilíndrico-cônica & 500 & 2 \\
\hline 5490 & $22^{\circ} 31^{\prime} 58,9^{\prime \prime}$ & $040^{\circ} 02^{\prime} 53,4^{\prime \prime}$ & $07 / 11 / 2001$ & oblíquo & $1.000 \mathrm{~m}$ & cilíndrico-cônica & 500 & 1 \\
\hline 5494 & $22^{\circ} 31^{\prime} 40,9^{\prime \prime}$ & $040^{\circ} 02^{\prime} 39,6^{\prime \prime}$ & $07 / 11 / 2001$ & oblíquo & $1.000 \mathrm{~m}$ & cilíndrico-cônica & 500 & 2 \\
\hline 7424 & $21^{\circ} 54^{\prime} 36,5^{\prime \prime}$ & $039^{\circ} 45^{\prime} 20,0^{\prime \prime}$ & $10 / 10 / 2001$ & oblíquo & $1.000 \mathrm{~m}$ & cilíndrico-cônica & 500 & 1 \\
\hline 7426 & $21^{\circ} 53^{\prime} 10,4^{\prime \prime}$ & $039^{\circ} 45^{\prime} 49,9^{\prime \prime}$ & $10 / 10 / 2001$ & oblíquo & $1.000 \mathrm{~m}$ & cilíndrico-cônica & 500 & 2 \\
\hline 19776 & $22^{\circ} 03^{\prime} 03,3^{\prime \prime}$ & $039^{\circ} 50^{\prime} 39,0^{\prime \prime}$ & $10 / 05 / 2002$ & oblíquo & até a termoclina & bongô & 500 & 1 \\
\hline
\end{tabular}

Referências: Ambrose, 1996d; Figueiredo \& Menezes, 2000; Richards, 2006i; Fahay, 2007. 


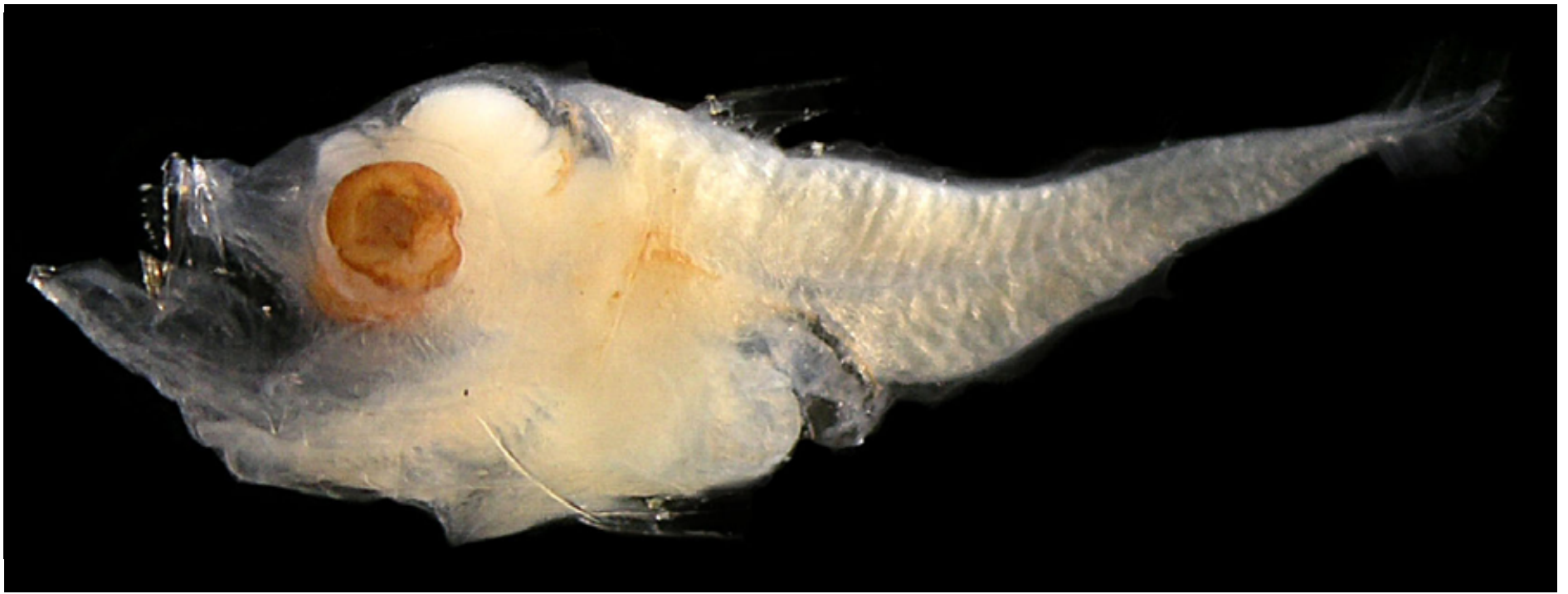

Figura 146 - A: Lepidocybium flavobrunneum. DZUFRJ 7425; Pré-flexão; CP 5,5 mm.

\section{Lepidocybium flavobrunneum (Smith, 1843)}

O corpo é alto e curto (31 miômeros) e o focinho é pontudo e curto. Desde o estágio de pré-flexão possui vários espinhos na cabeça, principalmente na região occipital, e pigmentos nas regiões mediana e posterior da cabeça, sobre o intestino, na membrana e na base da primeira nadadeira dorsal. Nadadeira dorsal: VIII-XXII, 16-18. Nadadeira anal: II, 10-14.

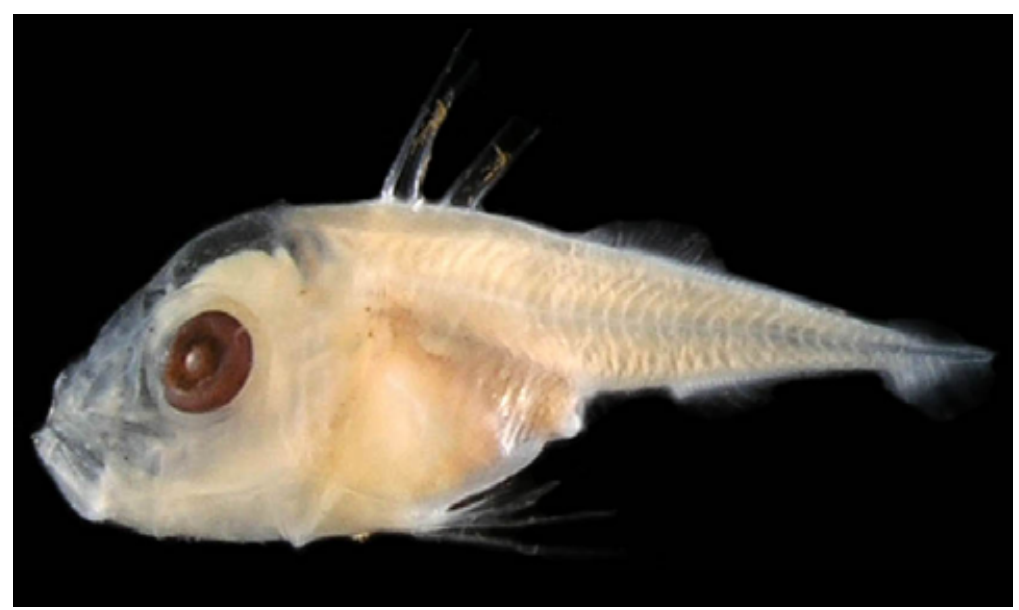

Figura 146 - B: DZUFRJ 5491; Flexão; CP 7,0 mm.

Tamanho: pré-flexão 4,0-5,5 mm; flexão 7,0 mm.

Habitat: espécie marinha, mesopelágica, ocorre em águas tropicais e subtropicais em profundidades superiores a $200 \mathrm{~m}$.

\section{Georreferenciamento}

\begin{tabular}{|c|c|c|c|c|c|c|c|c|}
\hline DZUFRJ & Latitude (S) & Longitude (W) & Data & $\begin{array}{c}\text { Tipo de } \\
\text { arrasto }\end{array}$ & $\begin{array}{c}\text { Profundidade } \\
\text { de coleta }\end{array}$ & Rede & $\begin{array}{c}\text { Malha } \\
(\boldsymbol{\mu m})\end{array}$ & $\begin{array}{c}\mathbf{N}^{\circ} \text {. de } \\
\text { inds. }\end{array}$ \\
\hline 5491 & $22^{\circ} 32^{\prime} 50,0^{\prime \prime}$ & $040^{\circ} 04^{\prime} 09,9^{\prime \prime}$ & $06 / 11 / 2001$ & oblíquo & $1.000 \mathrm{~m}$ & cilíndrico-cônica & 500 & 2 \\
\hline 7425 & $21^{\circ} 58^{\prime} 31,0^{\prime \prime}$ & $039^{\circ} 50^{\prime} 29,7^{\prime \prime}$ & $10 / 10 / 2001$ & oblíquo & $1.000 \mathrm{~m}$ & cilíndrico-cônica & 500 & 1 \\
\hline 22195 & $21^{\circ} 58^{\prime} 31,0^{\prime \prime}$ & $0^{\circ} 9^{\circ} 50^{\prime} 29,7^{\prime \prime}$ & $10 / 10 / 2001$ & oblíquo & $1.000 \mathrm{~m}$ & cilíndrico-cônica & 500 & 1 \\
\hline
\end{tabular}

Referências: Ambrose, 1996d; Figueiredo \& Menezes, 2000; Richards, 2006i; Fahay, 2007. 


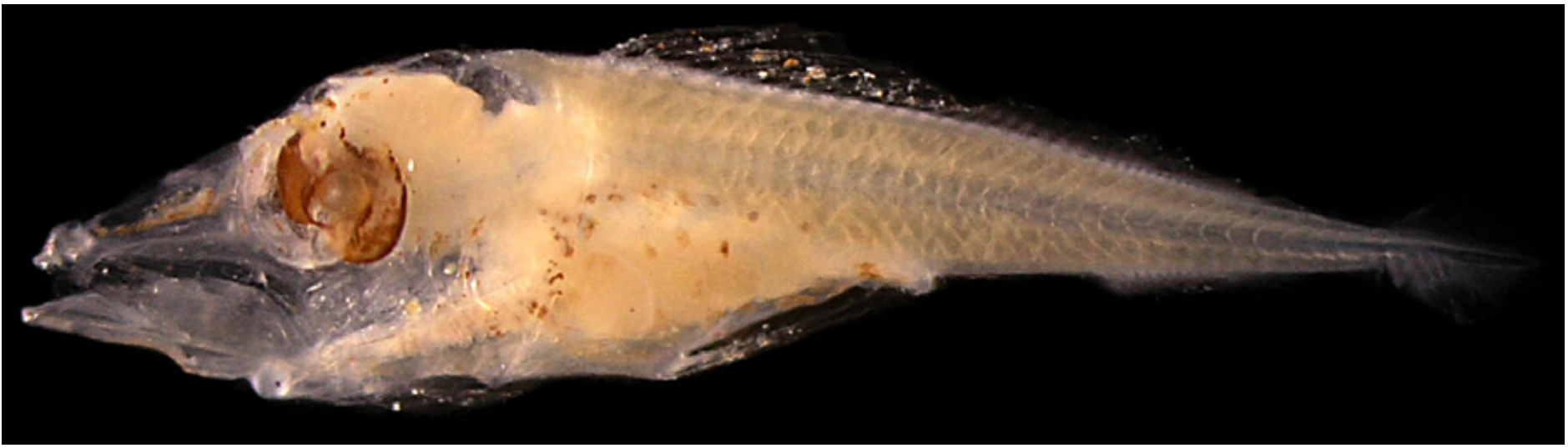

Figura 147 - A: Nesiarchus nasutus. DZUFRJ 7428; Pré-flexão; CP 6,8 mm.

\section{Nesiarchus}

\section{nasutus}

\section{Johnson, 1862}

Nadadeira dorsal: XIX-XXII+I, 19-22. Nadadeira anal: II-III, 15-17. O corpo (33-37 miômeros) e o focinho são alongados. A boca é grande e alguns dentes projetam-se na maxila inferior. Presença de uma linha de pigmentos na região nasal e gular. Possui pigmentação distribuída nas porções mediana e posterior da cabeça, sobre o intestino, na extremidade da mandíbula, entre os espinhos e na base da primeira nadadeira dorsal, e atrás dos olhos. Tem um grupo de pigmentos na base da notocorda.

Tamanho: pré-flexão 3,5-6,8 mm; flexão 7,1 mm.

Habitat: espécie marinha, mesopelágica e bentopelágica, ocorre em águas tropicais e subtropicais em profundidades entre 200 e $1.200 \mathrm{~m}$.

\section{Georreferenciamento}

\begin{tabular}{|c|c|c|c|c|c|c|c|c|}
\hline DZUFR & Latitude (S) & Longitude (W) & Data & $\begin{array}{c}\text { Tipo de } \\
\text { arrasto }\end{array}$ & $\begin{array}{c}\text { Profundidade } \\
\text { de coleta }\end{array}$ & Rede & $\begin{array}{c}\text { Malha } \\
\text { ( } \boldsymbol{\mu m})\end{array}$ & $\begin{array}{c}\text { No. de } \\
\text { inds. }\end{array}$ \\
\hline 1254 & $22^{\circ} 08^{\prime} 175^{\prime \prime}$ & $039^{\circ} 46^{\prime} 28,5^{\prime \prime}$ & $11 / 05 / 2002$ & oblíquo & $1.000 \mathrm{~m}$ & cilíndrico-cônica & 500 & 1 \\
\hline 7428 & $21^{\circ} 58^{\prime} 31,0^{\prime \prime}$ & $039^{\circ} 50^{\prime} 29,7^{\prime \prime}$ & $11 / 10 / 2001$ & oblíquo & $1.000 \mathrm{~m}$ & cilíndrico-cônica & 500 & 1 \\
\hline 19773 & $22^{\circ} 02^{\prime} 30,0^{\prime \prime}$ & $039^{\circ} 49^{\prime} 41,2^{\prime \prime}$ & $12 / 05 / 2002$ & oblíquo & até a termoclina & bongô & 500 & 1 \\
\hline 19775 & $22^{\circ} 06^{\prime} 522^{\prime \prime}$ & $039^{\circ} 48^{\prime} 46,2^{\prime \prime}$ & $11 / 05 / 2002$ & oblíquo & até a termoclina & bongô & 330 & 1 \\
\hline 22193 & $22^{\circ} 32^{\prime} 49 \mathbf{1}^{\prime \prime}$ & $040^{\circ} 04^{\prime} 20,9^{\prime \prime}$ & $07 / 11 / 2001$ & oblíquo & $1.000 \mathrm{~m}$ & cilíndrico-cônica & 500 & 1 \\
\hline
\end{tabular}

Referências: Ambrose, 1996d; Figueiredo \& Menezes, 2000; Richards, 2006i; Fahay, 2007.

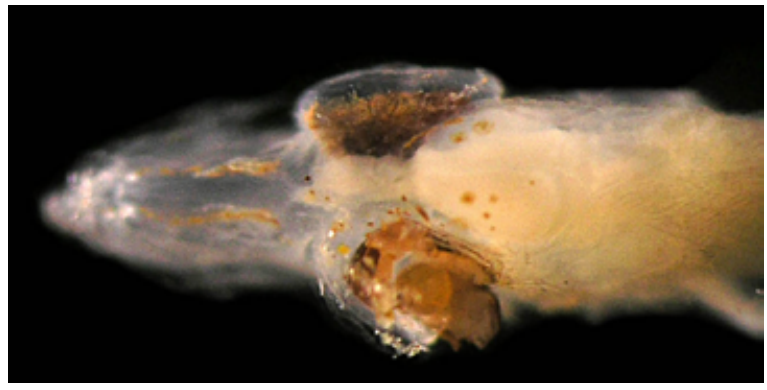

Figura 147 - C: Pigmentos na região nasal.

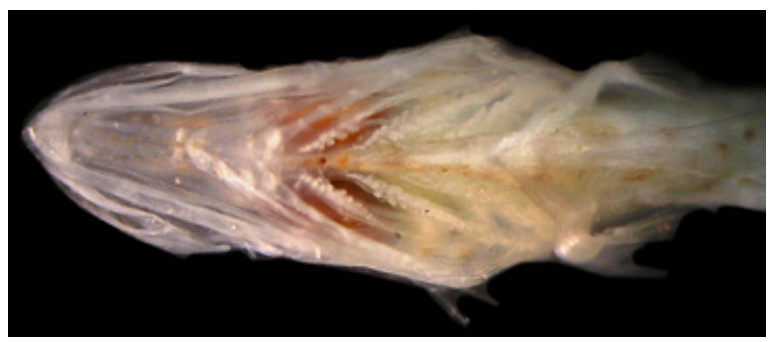

Figura 147 - D: Pigmentos na região gular.

Figura 147 - B: DZUFRJ 1254; Flexão; CP 7,1 mm.

西

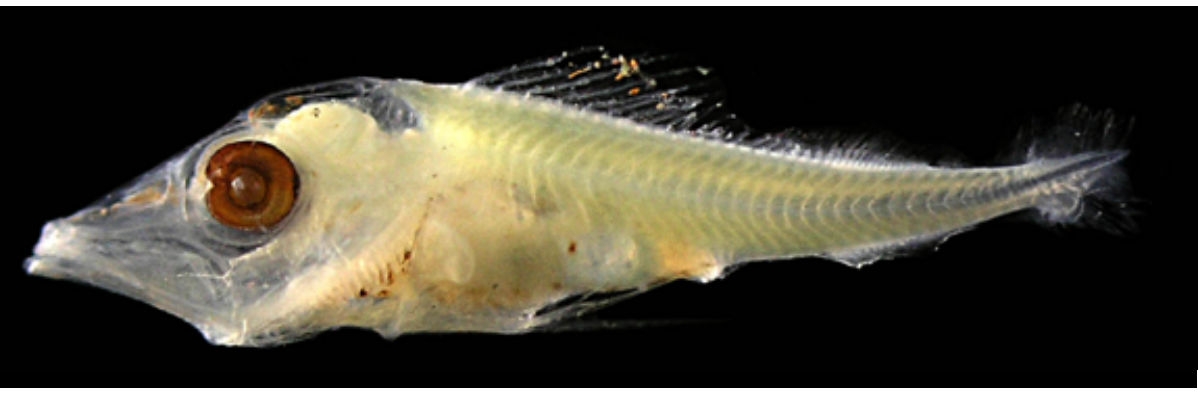




\section{Família Scombridae}

Devido a grande importância econômica dessa família, as espécies são muito estudadas e conhecidas pelo mundo. Compreende espécies marinhas, raramente, vivendo em água doce. Ocorrem em áreas tropicais e subtropicais. Abrange 15 gêneros com 51 espécies.

O formato do corpo, número de miômeros e a pigmentação são usados na identificação. O corpo é geralmente fusiforme (31 a 66 miômeros) e, em alguns casos, comprimido lateralmente. A cabeça é grande e o focinho pontudo, sendo a mandíbula muito desenvolvida. Possuem um espaço entre o ânus e o início da nadadeira anal cujo tamanho varia de acordo com a espécie. A pigmentação varia muito, estando sempre presente na cabeça, podendo ou não ocorrer próximo aos olhos e na margem ventral da cauda.

No Brasil, já foram identificadas 19 espécies nas fases de larva e adulto. Nesse estudo são contempladas as espécies Auxis thazard, Euthynnus alletteratus e Scomber colias. 


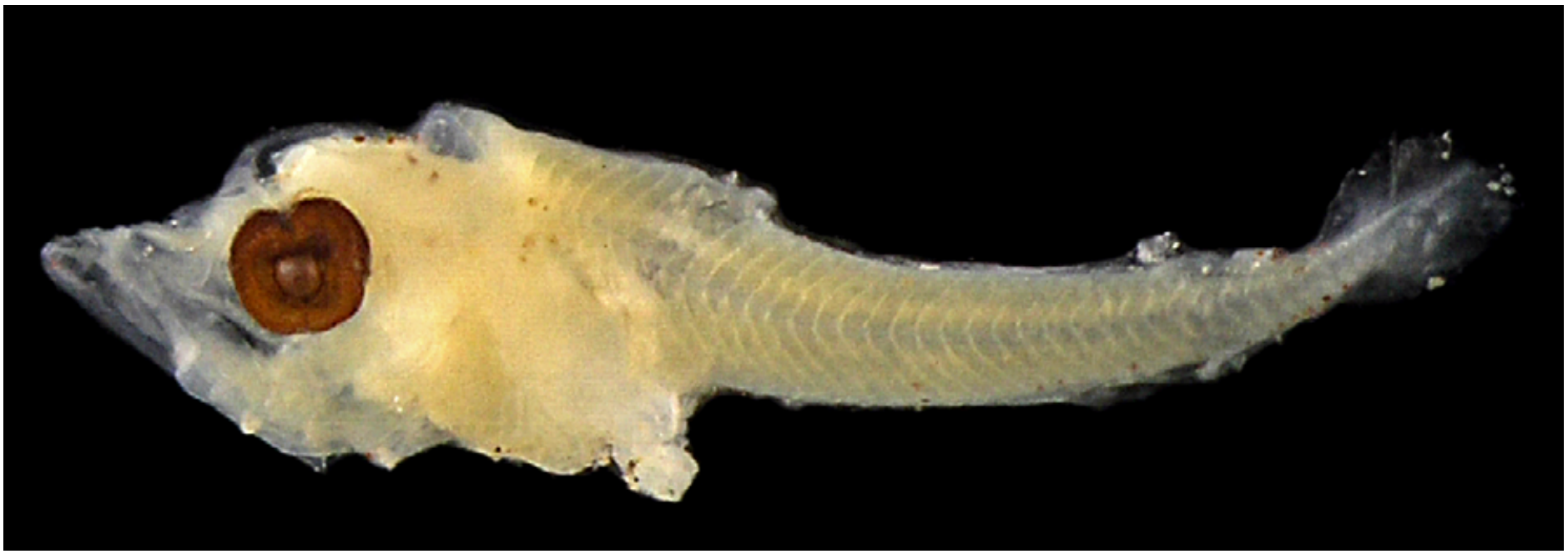

Figura 148: Auxis thazard. DZUFRJ 503; Flexão; CP 5,5 mm.

\section{Auxis thazard (Lacepède, 1800)}

O corpo é pouco alongado (39 miômeros), a cabeça é grande e a mandíbula é curta. O intestino é curto e em formato triangular. Presença de espinhos na cabeça e margem do opérculo e pré-opérculo. Pigmentos presentes na região mediana e posterior da cabeça, no cleitro e nas margens ventral e dorsal do corpo, incluindo o pedúnculo caudal. Uma fileira de pigmentos é encontrada na linha lateral, na porção posterior da cauda. Nadadeira dorsal: XX-XXII, 10-12; nadadeira anal: 11-14.

Tamanho: flexão 4,5-5,5 mm.

Habitat: espécie marinha, epipelágica, ocorre em águas quentes costeiras, oceânicas e próximo a ilhas.

Nome vulgar: Bonito cachorro.

\section{Georreferenciamento}

\begin{tabular}{|c|c|c|c|c|c|c|c|c|}
\hline DZUFR & Latitude (S) & Longitude (W) & Data & $\begin{array}{c}\text { Tipo de } \\
\text { arrasto }\end{array}$ & $\begin{array}{c}\text { Profundidade } \\
\text { de coleta }\end{array}$ & Rede & $\begin{array}{c}\text { Malha } \\
\text { ( } \boldsymbol{\mu m} \text { ) }\end{array}$ & $\begin{array}{c}\mathbf{N}^{\circ} \text {. de } \\
\text { inds. }\end{array}$ \\
\hline 407 & $22^{\circ} 31^{\prime} 27,0^{\prime \prime}$ & $040^{\circ} 16^{\prime} 56,0^{\prime \prime}$ & $17 / 05 / 2002$ & oblíquo & $600 \mathrm{~m}$ & cilíndrico-cônica & 500 & 2 \\
\hline 503 & $22^{\circ} 33^{\prime} 37,0^{\prime \prime}$ & $040^{\circ} 19^{\prime} 10,0^{\prime \prime}$ & $17 / 05 / 2002$ & oblíquo & $50 \mathrm{~m}$ & bongô & 500 & 1 \\
\hline
\end{tabular}

Referências: Ambrose, 1996e; Figueiredo \& Menezes, 2000; Collette, 2002b; Richards, 2006j; Fahay, 2007. Auxis thazard. DZUFRJ 503; Flexão; CP 5,5 mm. 


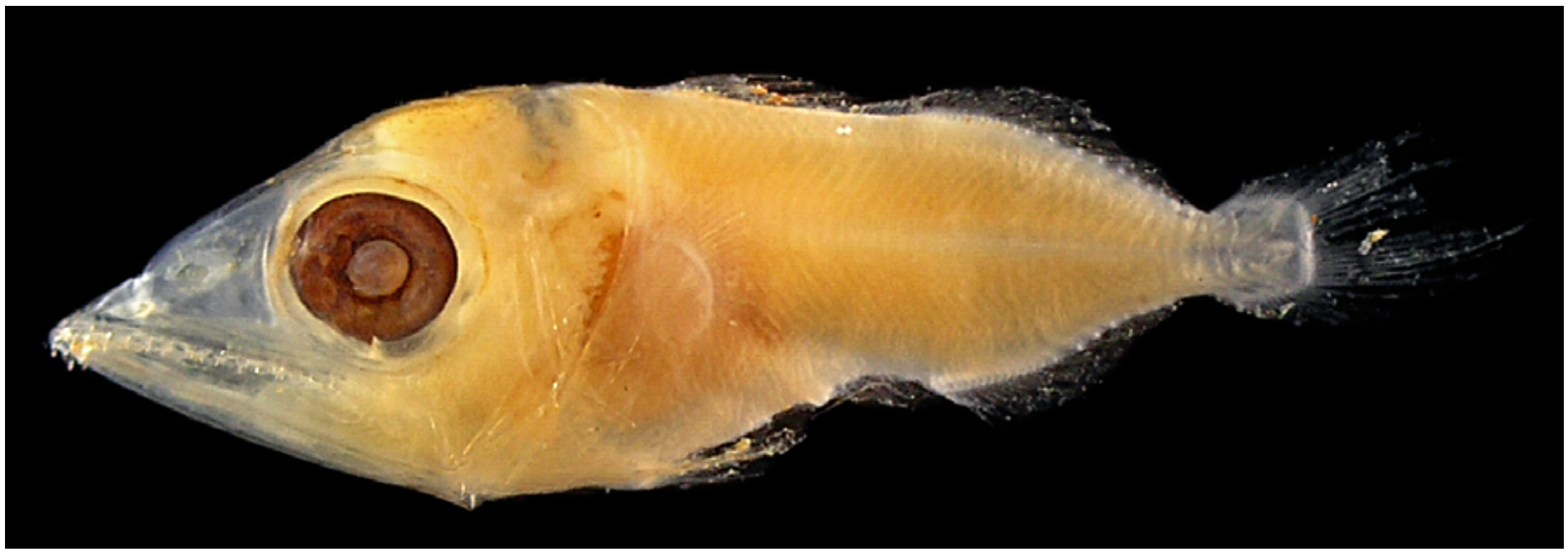

Figura 149 - Euthynnus alletteratus. DZUFRJ 7409; Flexão; CP 8,7 mm.

\section{Euthynnus alletteratus (Rafinesque, 1810)}

O corpo é pouco alongado (39 miômeros), a cabeça é grande, com focinho e mandíbula bem desenvolvida. O intestino é compacto e em formato triangular. Os espinhos da cabeça são moderadamente desenvolvidos, estando presentes também na margem do opérculo e pré-opérculo. Presença de pigmentos na região anterior e posterior da cabeça, na extremidade da mandíbula, formando uma fileira na maxila inferior, no cleitro e na margem ventral da cauda. Há pigmentos bem desenvolvidos na membrana entre os raios da primeira nadadeira dorsal. Nadadeira dorsal: XIII-XVII, 11-13; nadadeira anal: 11-15.

Tamanho: flexão 6,5-8,7 mm.

Habitat: espécie marinha, epipelágica, ocorre em águas tropicais e subtropicais em regiões neríticas, sobre a plataforma continental.

Nome vulgar: Bonito pintado.

\section{Georreferenciamento}

\begin{tabular}{|c|c|c|c|c|c|c|c|c|}
\hline DZUFRJ & Latitude (S) & Longitude (W) & Data & $\begin{array}{l}\text { Tipo de } \\
\text { arrasto }\end{array}$ & $\begin{array}{c}\text { Profundidade } \\
\text { de coleta }\end{array}$ & Rede & $\begin{array}{c}\text { Malha } \\
(\mu \mathrm{m})\end{array}$ & $\begin{array}{l}N^{\circ} \text {. de } \\
\text { inds. }\end{array}$ \\
\hline 7407 & $21^{\circ} 58^{\prime} 31,0^{\prime \prime}$ & $039^{\circ} 50^{\prime} 29,7^{\prime \prime}$ & $11 / 10 / 2001$ & oblíquo & $1.000 \mathrm{~m}$ & cilíndrico-cônica & 500 & 1 \\
\hline 7408 & $21^{\circ} 54^{\prime} 36,5^{\prime \prime}$ & $039^{\circ} 45^{\prime} 20,0^{\prime \prime}$ & $10 / 10 / 2001$ & oblíquo & $1.000 \mathrm{~m}$ & cilíndrico-cônica & 500 & 2 \\
\hline 7409 & $21^{\circ} 54 ' 36,5^{\prime \prime}$ & $039^{\circ} 45^{\prime} 20,0^{\prime \prime}$ & $10 / 10 / 2001$ & oblíquo & $1.000 \mathrm{~m}$ & cilíndrico-cônica & 500 & 1 \\
\hline 7412 & $21^{\circ} 58 ' 31,0^{\prime \prime}$ & $039^{\circ} 50^{\prime 29,7 ' "}$ & $10 / 10 / 2001$ & oblíquo & $1.000 \mathrm{~m}$ & cilíndrico-cônica & 500 & 1 \\
\hline
\end{tabular}

Referências: Ambrose, 1996e; Figueiredo \& Menezes, 2000; Collette, 2002b; Richards, 2006j; Fahay, 2007. 


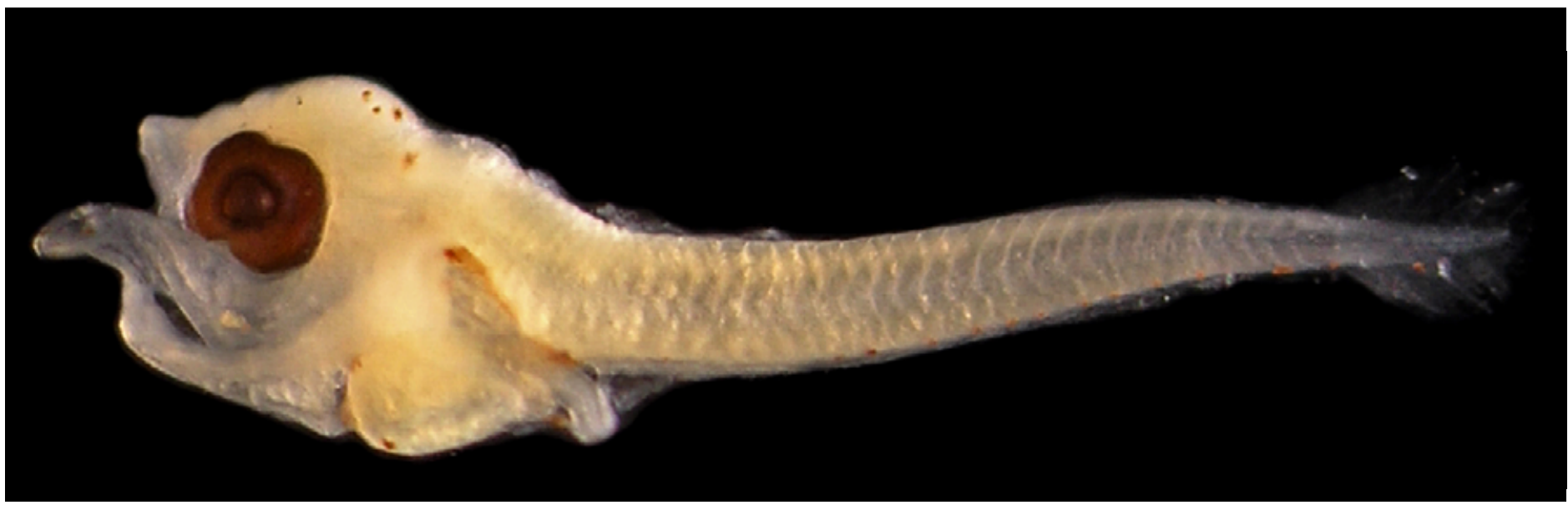

Figura 150: Scomber colias. DZUFRJ 361; Pré-flexão; CP 3,0 mm.

\section{Scomber colias Gmelin, 1789}

Possui poucos miômeros (31) e a primeira nadadeira dorsal tem desenvolvimento tardio. A cabeça é de tamanho mediano, com focinho arredondado e mandíbula pequena. $O$ intestino é compacto e em formato triangular. Não possui espinhos na cabeça. Tem pigmentos nas regiões anterior e posterior da cabeça, sobre o intestino e na margem ventral da cauda. Nadadeira dorsal: IX-XIII, 11-12; nadadeira anal: I, 11-14.

Tamanho: pré-flexão 3,0 mm.

Habitat: espécie marinha, epipelágica, ocorre em águas tropicais e temperadas, normalmente próximo à costa.

Nome vulgar: Cavala sardinheira.

\section{Georreferenciamento}

\begin{tabular}{|c|c|c|c|c|c|c|c|c|}
\hline DZUFRJ & Latitude (S) & Longitude (W) & Data & $\begin{array}{c}\text { Tipo de } \\
\text { arrasto }\end{array}$ & $\begin{array}{c}\text { Profundidade } \\
\text { de coleta }\end{array}$ & Rede & $\begin{array}{c}\text { Malha } \\
\text { ( } \boldsymbol{\mu m} \text { ) }\end{array}$ & $\begin{array}{c}\mathbf{N}^{\circ} \text {. de } \\
\text { inds. }\end{array}$ \\
\hline 361 & $22^{\circ} 38^{\prime} 25,0^{\prime \prime}$ & $040^{\circ} 17^{\prime} 41,0^{\prime \prime}$ & $19 / 05 / 2002$ & oblíquo & $40 \mathrm{~m}$ & bongô & 330 & 1 \\
\hline
\end{tabular}

Referências: Ambrose, 1996e; Figueiredo \& Menezes, 2000; Collette, 2002b; Richards, 2006j; Fahay, 2007. 


\section{Família Nomeidae}

Os representantes da família Nomeidae são pelágicos, com exceção da espécie Nomeus gronovii, cujos adultos são demersais. Compreende três gêneros com aproximadamente 16 espécies.

As larvas e juvenis possuem o corpo afilado ou alto com 30-40 miômeros. As nadadeiras dorsal e anal são semelhantes em tamanho e posicionamento. Apesar da sobreposição, algumas espécies podem ser separadas pelas características merísticas. A linha lateral acompanha o perfil dorsal do corpo, não se estendendo até o curto pedúnculo caudal.

No Brasil, já foram identificadas sete espécies nas fases de larva e adulto. Nesse estudo é contemplada a espécie Psenes cyanophrys. 


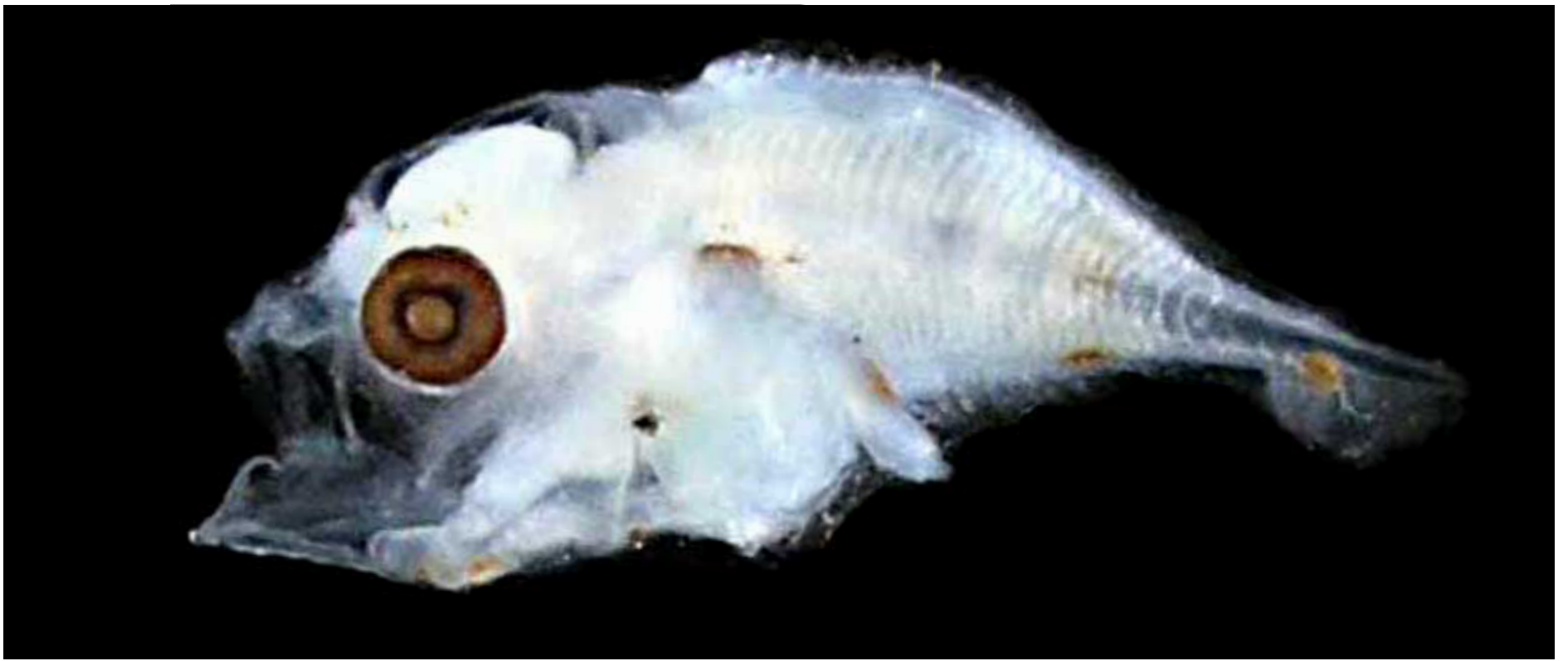

Figura 151 - A: Psenes cyanophrys. DZUFRJ 2624; Pré-flexão; CP 4,0 mm.

\section{Psenes cyanophrys Valenciennes, 1833}

Possui o corpo curto (31 miômeros) e alto. Os espinhos do opérculo e pré-opérculo são fracos. Durante o estágio de pré-flexão, a nadadeira pélvica já está formada e bem desenvolvida. No estágio de pré-flexão a pigmentação concentra-se na porção posterior do corpo entre a linha lateral e as margens dorsal e anal e na base da notocorda. Durante a flexão, formam-se manchas no topo da cabeça e há uma concentração de pigmentos nos raios da nadadeira pélvica. Presença de pigmentos peritoneais na margem dorsal do intestino e de uma mancha próxima ao ânus. No estágio de pós-flexão, formam-se bandas de pigmentos pelo corpo, entre os miômeros 20 e 23. Uma única mancha concentra-se na base da notocorda. Em juvenis, formam-se 4-5 barras atravessando o corpo, da parte posterior da cabeça até o pedúnculo caudal.

Tamanho: pré-flexão 4,0 mm; flexão 4,3-4,5 mm; pós-flexão 7,2 mm; transformação 31,0 mm.

Habitat: espécie marinha, epipelágica e mesopelágica, ocorre em águas tropicais e subtropicais em áreas oceânicas.

Nome vulgar: Rombudo.

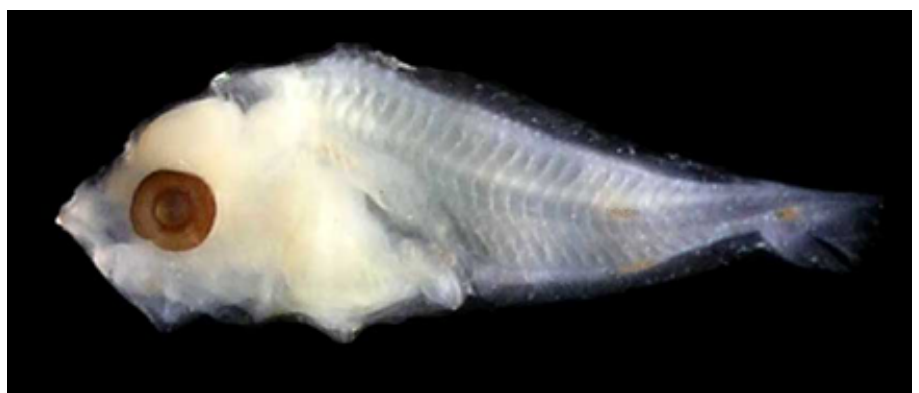

Figura 151 - B: DZUFRJ 22386; Flexão; CP 4,5 mm.

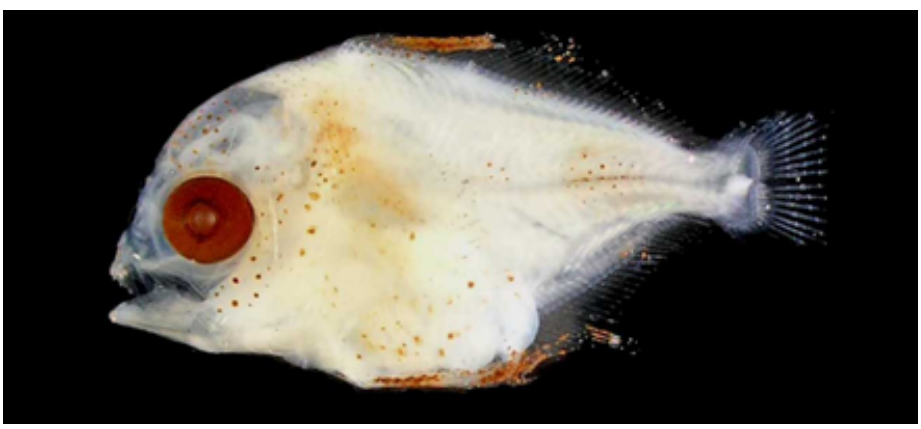

Figura 151 - C: DZUFRJ 21383; Pós-flexão; CP 7,2 mm.

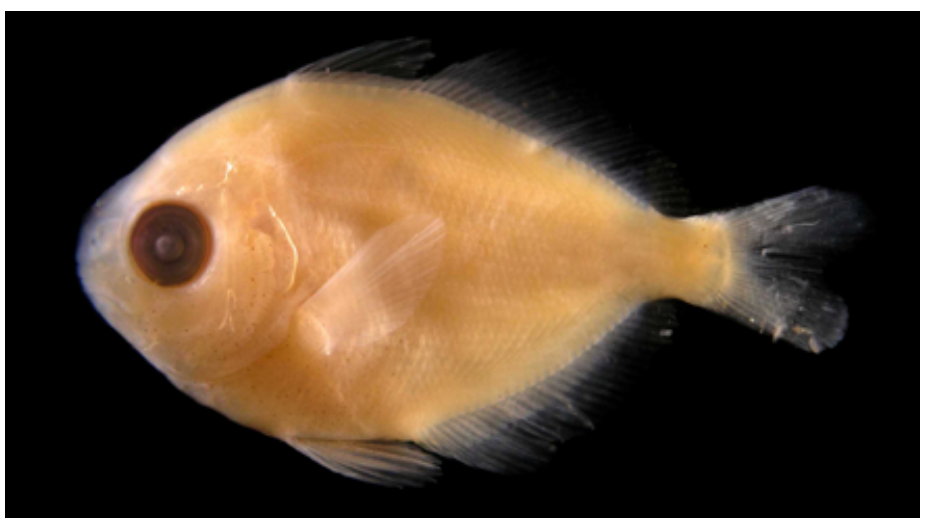

Figura 151 - D: DZUFRJ 22385; Transformação; CP 31,0 mm. 


\section{Georreferenciamento}

\begin{tabular}{|c|c|c|c|c|c|c|c|c|}
\hline DZUFRJ & Latitude (S) & Longitude (W) & Data & $\begin{array}{c}\text { Tipo de } \\
\text { arrasto }\end{array}$ & $\begin{array}{c}\text { Profundidade } \\
\text { de coleta }\end{array}$ & Rede & $\begin{array}{c}\text { Malha } \\
\text { ( } \boldsymbol{\mu m})\end{array}$ & $\begin{array}{c}\mathbf{N}^{\circ} \text {. de } \\
\text { inds. }\end{array}$ \\
\hline 2624 & $22^{\circ} 35^{\prime} 08,5^{\prime \prime}$ & $039^{\circ} 46^{\prime} 22,3^{\prime \prime}$ & $06 / 12 / 2002$ & horizontal & superfície & nêuston & 500 & 1 \\
\hline 2684 & $22^{\circ} 43^{\prime} 50,4^{\prime \prime}$ & $039^{\circ} 53^{\prime} 20,5^{\prime \prime}$ & $07 / 12 / 2002$ & horizontal & superfície & nêuston & 500 & 1 \\
\hline 21383 & $22^{\circ} 02^{\prime} 35,2^{\prime \prime}$ & $039^{\circ} 43^{\prime} 18,2^{\prime \prime}$ & $04 / 12 / 2002$ & vertical & $700-1.200 \mathrm{~m}$ & cilíndrico-cônica & 200 & 1 \\
\hline 22385 & $21^{\circ} 57^{\prime} 114^{\prime \prime}$ & $039^{\circ} 37^{\prime} 27,9^{\prime \prime}$ & $05 / 12 / 2002$ & vertical & $0-40 \mathrm{~m}$ & cilíndrico-cônica & 200 & 1 \\
\hline 22386 & $22^{\circ} 35^{\prime} 08^{\prime \prime} 5^{\prime \prime}$ & $039^{\circ} 46^{\prime} 22,3^{\prime \prime}$ & $06 / 12 / 2002$ & vertical & $0-50 \mathrm{~m}$ & cilíndrico-cônica & 200 & 1 \\
\hline
\end{tabular}

Referências: Watson, 1996l; Figueiredo \& Menezes, 2000; Last, 2002; Lamkin, 2006; Fahay, 2007. 